\title{
A DESREGULAÇÃO DA VIA UPR \\ ASSOCIADA À IMUNODEFICIÊNCIA \\ COMUM VARIÁVEL
}

Dissertação de Mestrado apresentada ao Instituto de Ciências Biomédicas da Universidade de São Paulo, para obtenção do Título de Mestre em Ciências (Imunologia)

São Paulo

2007 


\section{A DESREGULAÇÃO DA VIA UPR ASSOCIADA \\ À IMUNODEFICIÊNCIA COMUM VARIÁVEL}

Dissertação de Mestrado apresentada ao Instituto de Ciências Biomédicas da Universidade de São Paulo, para obtenção do Título de Mestre em Ciências.

Área de concentração: Imunologia

Orientadora: Prof. Dr. Maristela Martins de Camargo

São Paulo

2007 


\section{UNIVERSIDADE DE SÃO PAULO \\ INSTITUTO DE CIÊNCIAS BIOMÉDICAS}

Candidata: Juliana Sayuri Kuribayashi

Título da Dissertação: $\quad$ A desregulação da via UPR associada à Imunodeficiência Comum Variável

Orientadora: $\quad$ Maristela Martins de Camargo

A Comissão Julgadora dos Trabalhos de Defesa da Dissertação de Mestrado, em sessão pública realizada a ......................., considerou
( ) Aprovada
( ) Reprovada

Examinador (a) Assinatura

Nome

Instituição

Examinador (a) Assinatura

Nome

Instituição

Presidente Assinatura

Nome

Instituição 
Aos meus pais, por fazerem dos meus sonhos os seus sonhos também

Aos meus irmãos, pelo carinho e lealdade

\footnotetext{
À minha tia Mitika, Yumi e Carol, por me acolherem com tanto carinho
}

Ao Lívio, por estar sempre ao meu lado me apoiando e incentivando 


\section{AGRADECIMENTOS}

À Dra. Maristela Martins de Camargo pela oportunidade de crescer cientificamente e pela confiança em meu trabalho.

Ao Dr. Luiz Vicente Rizzo pela colaboração e contribuição indispensáveis à realização deste trabalho.

Às Dras. Cristina Kokron e Myrthes Toledo Barros do Serviço de Imunologia e Alergia do Hospital de Clínicas da Universidade de São Paulo que, juntamente com o Dr. Luiz Vicente Rizzo, viabilizaram as coletas das amostras dos pacientes.

À Rosana Vieira Coutinho pela presteza na coleta das amostras dos pacientes. À Dra. Luiza Guilherme Guglielmi e Sandra Emiko Oshiro pela imortalização dos linfócitos B.

Aos Drs. Júlio Aliberti e Fabiana Machado, do Children's Hospital Medical Center, Cincinnati, Estados Unidos, pelos experimentos de Microscopia Confocal.

Aos Drs. Beatriz Amaral de Castilho, Frederico José Gueiros-Filho, João Gustavo Pessini Amarante Mendes e José Alexandre Marzagão Barbuto pelas contribuições valiosas no exame de qualificação.

À técnica Cláudia da Silva Cunha pelo carinho e por me ajudar sempre que necessário.

Às colegas de laboratório Fernanda Fidelis Gonsalez Guimarães, Mônica Zandoná Meleiro e Nicolle Gilda Texeira Queiroz pelo companheirismo, lealdade e carinho. 
À Cíntia Raquel Bombardieri por ter sido mais que uma colega de laboratório, por ter sido minha amiga de todas as horas e minha companhia em todos os momentos.

Aos meus amigos Clara Maciel Cavalcanti, Luciana Vieira Carvalho, Márcio Yuiti Tomiyoshi, Mariane Tami Amano, Rafael Assumpção Larocca, Ricardo Weinlich e Welbert Oliveira Pereira pelas discussões científicas produtivas, pela amizade e pelos momentos de descontração.

Aos amigos do Departamento de Imunologia do ICB - USP pela amizade e presteza em compartilhar conhecimentos e experiências.

Aos docentes do Departamento de Imunologia do ICB - USP por sempre estarem de portas abertas dispostos a compartilhar tanto reagentes quanto ensinamentos.

Às secretárias Jotelma Ribeiro Leite, Maria Eni do Sacramento Santos e Valéria Machado dos Santos pela eficiência e enorme paciência.

Aos funcionários da portaria, segurança, limpeza, áudio-visual e biblioteca pelo suporte que permitiu a realização deste trabalho. 
A bad beginning makes a bad ending.

Euripides

A hard beginning maketh a good ending.

John Heywood 


\section{RESUMO}

KURIBAYASHI, J. S. A desregulação da via UPR associada à imunodeficiência comum variável. 2007. Dissertação (Mestrado em Imunologia). Instituto de Ciências Biomédicas. Universidade de São Paulo, São Paulo, 2007.

A imunodeficiência comum variável (CVID) é uma imunodeficiência primária caracterizada por hipogamaglobulinemia e infecções recidivantes. Nós verificamos o papel da via Unfolded Protein Response (UPR) na patogênese da doença. Nós descrevemos os resultados obtidos a partir da análise de 21 pacientes com CVID. Métodos: Western-blot, RT- e Q-PCR, seqüenciamento de DNA e análise por microscopia confocal de células mononucleares do sangue periférico, linfócitos $B$ ex vivo ou linfócitos $B$ imortalizados por vírus Epstein-Barr. Resultados: Uma paciente com CVID apresentou expressão aumentada do RNAm XBP-1 unspliced e co-localização de IgM e BiP/GRP78 no retículo endoplasmático (RE). Verificamos a ausência de mutações nos produtos obtidos por RT-PCR tanto no XBP-1 quanto nos domínios quinase/endonuclease da IRE-1 $\alpha$ que poderiam impedir o splicing do RNAm XBP-1. A análise por microscopia confocal mostrou que as células da paciente são maiores e não apresentam a distribuição típica de IgM na superfície celular. As moléculas de IgM acumulam-se no RE anormalmente aumentado. Análises por Q-PCR dos RNAm XBP-1 spliced, IRE-1 $\alpha$ e BiP após tratamento com LPS e brefeldina A mostrou que, ao contrário dos controles saudáveis que respondem a estes estressores do RE com ondas de transcrição destes três genes, esta paciente apresenta baixos níveis de transcrição, não atingindo o mesmo nível de resposta apresentado pelos indivíduos saudáveis. Conclusões: Nossos achados associam o splicing diminuído do RNAm XBP-1 ao acúmulo de IgM no RE e baixas taxas de transcrição de chaperonas, fornecendo um mecanismo para explicar a hipogamaglobulinemia observada em uma paciente com CVID.

Palavras-chave: CVID. Via UPR. Imunoglobulinas. Linfócitos B. XBP-1. 
KURIBAYASHI, J. S. Dysregulation of Unfolded Protein Response associated with Common Variable Immunodeficiency. 2007. Master thesis (Immunology). Instituto de Ciências Biomédicas. Universidade de São Paulo, São Paulo, 2007.

Background: Common Variable Immunodeficiency (CVID) is a primary immunodeficiency characterized by hypogammaglobulinemia and recurrent infections. Herein we addressed the role of Unfolded Protein Response (UPR) in the pathogenesis of the disease. We describe findings obtained through a screen performed among 21 CVID patients. Methods: Western-blot, RT- and Q-PCR, DNA sequencing and confocal microscopy analysis were performed in ex-vivo and LPS-activated PBMC, isolated B cells or EBV-immortalized B cells. Results: Augmented unspliced XBP-1 mRNA concurrent with co-localization of IgM and BiP/GRP78 was found in one CVID patient. Sequencing of RT-PCR amplicons did not reveal any mutation on XBP-1 neither on the kinase/endonuclease domains of IRE-1a that could potentially prevent the splicing to occur. At confocal microscopy analysis this patient's cells were enlarged and failed to present the typical surface distribution of IgM, which accumulated within an abnormally large ER. Q-PCR analysis of spliced XBP-1, IRE-1a and BiP after LPS or brefeldin A treatment showed that, unlike healthy controls that respond to these ER stressors by presenting waves of transcription of these three genes, this patient presented lower rates of transcription, not reaching the same level of response of healthy subjects. Conclusions: Our findings associate diminished splicing of XBP-1 mRNA with accumulation of IgM within the ER and lower rates of chaperone transcription, therefore providing a mechanism to explain the hypogammaglobulinemia observed in one CVID patient.

Key words: CVID. UPR pathway. Immunoglobulins. B cells. XBP-1. 


\section{LISTA DE ABREVIATURAS E SIGLAS}

ADP - do inglês adenosine diphosphate

AMP - do inglês adenosine monophosphate

APRIL - do inglês A proliferation-inducing ligand

ATF - do inglês activating transcription factor

ATP - do inglês adenosine triphosphate

BAFF - do inglês $B$ cell-activating factor

BAFFR - receptor da molécula BAFF

BCL-6 - do inglês $B$ cell leukemia/lymphoma-6

BCMA - do inglês $B$ cell maturation protein $A$

$\mathrm{BCR}$ - do inglês $B$ cell receptor (receptor de linfócito $B$ )

$\mathrm{BiP}$ - do inglês binding protein

BLIMP-1 - do inglês $B$ lymphocyte inducer of maturation program 1

bZIP - do inglês basic leucin-zipper

cAMP - do inglês cyclic adenosine monophosphate

$\mathrm{CD}$ - do inglês cluster of differentiation

cDNA - DNA complementar

C/EBP - do inglês CCAAT enhancer binding protein

CG - centro germinativo

$\mathrm{CHOP}$ - do inglês C/EBP-homologous protein

CREB - do inglês cAMP response-element-binding

CVID - do inglês Common Variable Immunodeficiency (imunodeficiência comum variável)

DC - do inglês dendritic cell (célula dendrítica)

EBV - do inglês Epstein Barr vírus (vírus Epstein Barr)

elF2 $\alpha$ - do inglês eucaryotic translation initiation factor 2, $\alpha$ subunit (subunidade alfa do fator de iniciação da tradução 2)

ERAD - do inglês ER-associated degradation (degradação associada ao RE)

ERSE - do inglês ER stress element response (elemento responsivo ao estresse do $\mathrm{RE})$

GADD 34 - do inglês growth arrest and DNA damage-inducible gene 34

GRP - do inglês glucose-regulated protein 
HBSS - do inglês Hanks' Balanced Salt Solution

HIV - do inglês human immunodeficiency virus (vírus da imunodeficiência humana)

HLA-DR - do inglês human leucocyte antigen-DR

ICOS - do inglês inducible costimulator

ICOSL - ligante da molécula ICOS

$\lg$ - imunoglobulina

$\mathrm{IL}$ - interleucina

IRE1 - do inglês inositol-requiring enzyme 1

JNK - do inglês Jannus Kinase

LPS - lipopolissacarídeo

MHC II - do inglês major histocompatibility complex II (complexo principal de histocompatibilidade de classe II)

NK - do inglês natural killer

ORF - do inglês open reading frame (fase de leitura aberta)

PBMC - do inglês peripheral blood mononuclear cell (célula mononuclear de sangue periférico)

PERK - do inglês PKR-like ER kinase

PP1 - proteína fosfate 1

RAG - do inglês recombination activating gene

RE - Retículo Endoplasmático

RNAm - RNA mensageiro

$\mathrm{TACl}$ - do inglês transmembrane activator and calcium-modulator and cyclophilin ligand interactor

Th - do inglês $T$ helper

TNF - do inglês tumor necrosis factor (fator de necrose tumoral)

TNFRSF13B - gene codificador da proteína TACI

TRAF2 - do inglês TNF receptor-associated factor 2

UPR - do inglês Unfolded Protein Response

UPRE - do inglês unfolded protein response element (elemento responsivo a proteínas não dobradas)

XBP-1 - do inglês $X$-box binding protein 1 
1.1. Imunodeficiência Comum Variável

1.2. Estresse do RE e via UPR

1.3. XBP-1 e diferenciação de plasmócitos

2. Objetivos

3.2. Isolamento das células mononucleares do sangue periférico

3.3. Caracterização das células mononucleares do sangue periférico

3.4. Separação de linfócitos B e não-B por MACS Beads

3.5. Microscopia Confocal (PCR)

3.9. Reação em cadeia da polimerase (PCR) em tempo real

3.10. Seqüenciamento

3.11. Ensaio de estresse celular

3.12. Ativação de linfócitos B com LPS

3.14. Imortalização dos linfócitos B 48

3.15. Caracterização fenotípica dos linfócitos B imortalizados 49

3.16. Marcação com AnexinaV-FITC e lodeto de Propídio 49

4. Resultados e Discussão

4.1. Caracterização fenotípica da paciente $P$ 
4.2. Localização intracelular de cadeias IgM nos plasmócitos da paciente $P$

4.3. Análise da expressão do RNAm para XBP-1 nos pacientes com CVID

4.4. Seqüenciamento do RNAm do XBP-1 da paciente $P$

4.5. Ensaios de estresse celular para ativação da via UPR em uma população celular enriquecida com linfócitos B

4.6. Apoptose desencadeada pela ativação da via UPR por brefeldina A nas células B ex vivo

4.7. Diminuição do estresse celular de células ex vivo com a utilização de chaperona química

4.8. Ativação de células ex vivo com LPS

4.9. Caracterização dos linfócitos B imortalizados com vírus Epstein-Barr

4.10. Ensaios de estresse celular com brefeldina A para ativação da via UPR nos linfócitos B imortalizados com vírus Epstein-Barr

4.11. Diminuição do estresse celular de linfócitos $B$ imortalizados com a utilização de chaperona química

4.12. Ensaio de estresse celular com LPS para ativação da via UPR nos linfócitos B imortalizados com o vírus Epstein-Barr

4.13. Seqüenciamento do RNAm da IRE-1a da paciente $P$ 


\section{INTRODUÇÃO}

\subsection{Imunodeficiência Comum Variável}

A Imunodeficiência Comum Variável (CVID - common variable immunodeficiency) é uma das imunodeficiências primárias mais freqüentemente diagnosticada e apresenta sinais clínicos bastante variados (Kainulainen 2001). Esta heterogeneidade de manifestações levou alguns autores a considerar a CVID como uma síndrome cuja principal característica é a apresentação de baixos níveis séricos de imunoglobulinas (Schwartz 1999; Kainulainen 2001).

Os aspectos clínicos apresentados pelos indivíduos com CVID incluem uma maior susceptibilidade a infecções nos tratos respiratório e gastrointestinal ocasionada por bactérias encapsuladas (Cunningham-Rundles 1999). Diarréia crônica de origem não infecciosa e mal-absorção de nutrientes podem estar presentes (Washington 1996; Cunningham-Rundles 1999). Alguns subgrupos de pacientes também apresentam risco aumentado de desenvolverem esplenomegalia, lesões granulomatosas, doenças autoimunes e neoplasias (Fischer 2004; Bayry 2005).

O diagnóstico geralmente é feito após histórico de infecções sinopulmonares piogênicas recidivantes, caracterização de uma deficiência na produção de anticorpos e exclusão de outras imunodeficiências (Cunningham-Rundles 1989; Cunningham-Rundles 1999; Kokron 2004). A sobrevida de 20 anos após o diagnóstico é de $64 \%$ para os pacientes do sexo masculino e $67 \%$ para as mulheres (Cunningham-Rundles 1999). 
A incidência da CVID é de 1 para cada 10.000 - 50.000 nascidos vivos (Tiller 2000; Kainulainen 2001; Sneller 2001). Esta doença acomete igualmente homens e mulheres e pode ser diagnosticada em qualquer fase da vida, desde a infância até a idade adulta (Cunningham-Rundles 1989).

A CVID apresenta um padrão de distribuição predominantemente esporádico, sendo que cerca de $20 \%$ dos casos ocorrem em grupos familiares com transmissão autossômica dominante (Nijenhuis 2001). Em alguns casos familiares, a CVID freqüentemente acomete um indivíduo enquanto seus descendentes apresentam deficiência de IgA. Isto é consistente com a hipótese de que, em alguns casos, a deficiência de IgA progride para CVID (Vorechovsky 1999).

Alguns pacientes apresentam flutuações nos níveis de imunoglobulinas séricas, o que induziu alguns pesquisadores a cogitarem a possibilidade de a CVID não ser decorrente de um defeito genético irreversível. Existem relatos de pacientes com títulos normais de anticorpos que gradativamente apresentaram agamaglobulinemia; além de pacientes com deficiência de IgA que evoluiu para uma deficiência dos outros isotipos de imunoglobulinas. O contrário também foi descrito, pacientes com deficiência na produção de imunoglobulinas que apresentaram melhora do quadro clínico e restabelecimento da produção normal de imunoglobulinas (Seggev 1991; Seligmann 1991; Johnson 1997; CunninghamRundles 1999).

Alguns estudos dividem os pacientes com CVID em subgrupos de acordo com as alterações moleculares e funcionais presentes. No entanto, não existem subgrupos bem estabelecidos em razão do amplo espectro clínico e características fenotípicas variadas, impossibilitando a associação da CVID com uma única causa (Bayry 2005). Além disso, a predisposição genética e defeitos múltiplos tanto nos 
compartimentos inato quanto adaptativo do sistema imune podem contribuir para a sintomatologia heterogênea da CVID (figura 1).

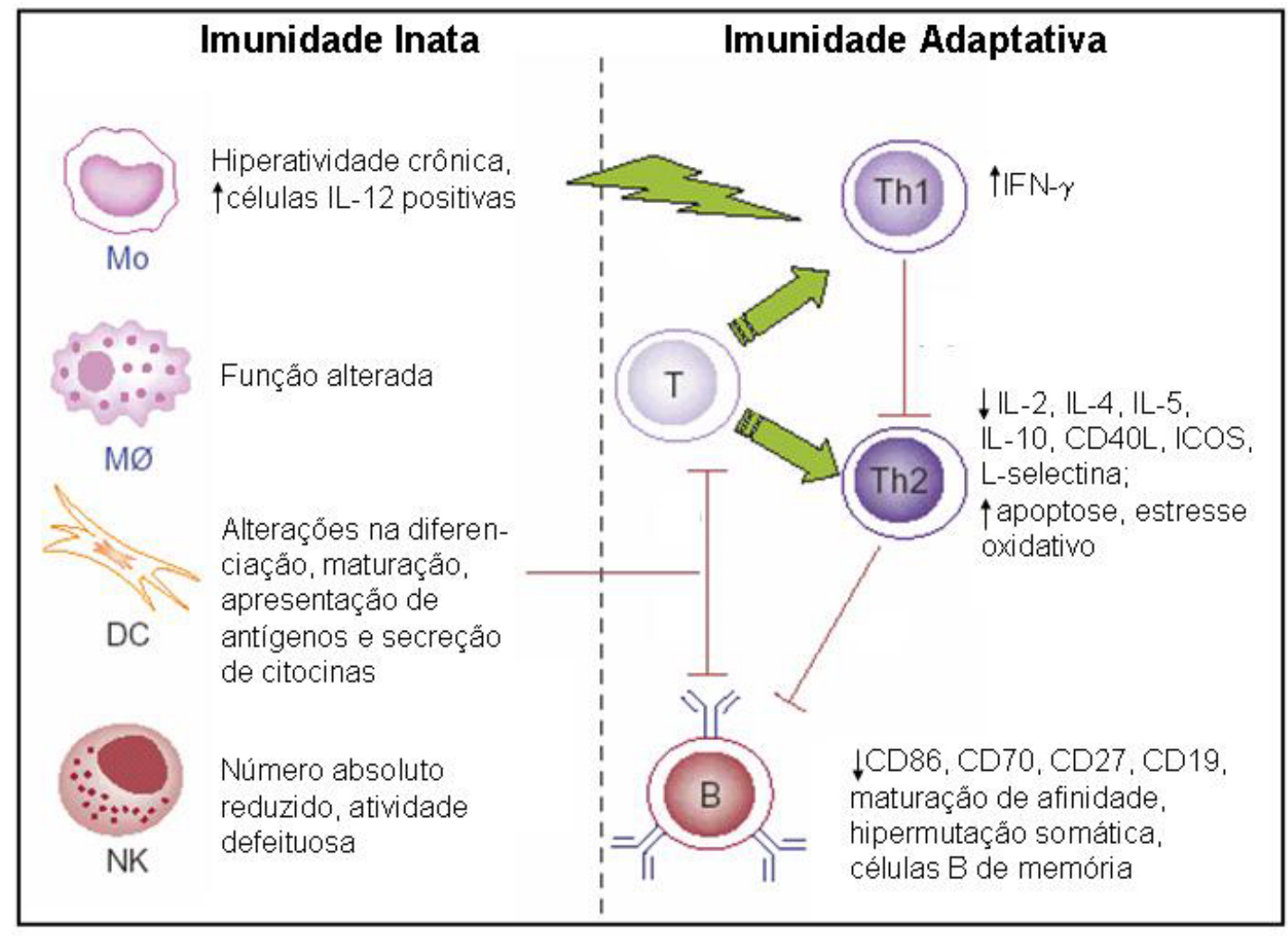

Figura 1: Representação esquemática dos defeitos nos vários compartimentos do sistema imune em pacientes com CVID. Defeitos nos compartimentos inato (células dendríticas, macrófagos, monócitos e células NK) e adaptativo (linfócitos T e B) foram observados em pacientes com CVID. No entanto, defeitos no sistema imune adaptativo pode ser secundário à defeitos em outras células acessórias. Deficiências na função de células dendríticas podem prejudicar as respostas de linfócitos $T$ e $B$ antígeno-específicos. Alternativamente, monócitos cronicamente ativados produtores de IL-12 podem polarizar para uma resposta Th1 em pacientes com CVID, que por sua vez inibe as respostas Th2 e por linfócitos B. Abreviações: B, linfócitos B; DC, células dendríticas; ICOS, inducible co-stimulatory molecule; IFN, interferon; M $\varnothing$, macrófagos; Mo, monócitos; NK, células NK; T, linfócitos T. Adaptado de Bayry 2005.

A produção de imunoglobulinas é o resultado final de uma série de eventos com a participação de elementos tanto da imunidade inata quanto da adaptativa. Desta forma, a hipogamaglobulinemia pode resultar de falhas desde a apresentação do antígeno até a secreção das imunoglobulinas. As células dendríticas (DCs) podem apresentar defeitos que ocasionam o fenótipo da CVID e de fato existem 
relatos de alguns pacientes apresentando diferenciação e maturação comprometidas, expressão diminuída de moléculas co-estimuladoras como CD80, CD86 e HLA-DR e produção deficiente de interleucina (IL)-12. Estes defeitos intrínsecos às DCs levam ao prejuízo da ativação e proliferação de linfócitos T e conseqüentemente comprometem a maturação de linfócitos B (Bayry 2004; Cunningham-Rundles 2005a).

Pacientes com CVID também podem apresentar números reduzidos de células NK (natural killer). Estas células constituem um importante componente do sistema imune inato por reconhecer e lisar células tumorais e infectadas por vírus (Aspalter 2000; Amoras 2003; Bayry 2005). Não foi observada uma conseqüência clínica óbvia relacionada à diminuição destas células nos pacientes com CVID, mas esta deficiência pode estar relacionada aos problemas secundários apresentados pelos pacientes como, por exemplo, a incidência aumentada de tumores malignos (Bayry 2005).

Alterações no perfil de citocinas produzidas durante uma resposta imune também podem prejudicar a produção de imunoglobulinas. Um subgrupo de pacientes com CVID apresentou monócitos cronicamente ativados produzindo grandes quantidades de IL-12. O excesso desta citocina induz uma polarização da resposta imune para um perfil Th1 que por sua vez inibe o perfil Th2. Sabe-se que as citocinas produzidas pelas células Th2 são essenciais na diferenciação terminal de linfócitos $B$ e na indução de troca de classes de imunoglobulinas. Desta forma, a predominância do perfil Th1 nestes pacientes foi considerada a causa da hipogamaglobulinemia (Aukrust 1994; Bayry 2005).

Um grande número de defeitos em linfócitos $T$ também foi descrito em pacientes com CVID. Dentre as alterações observadas podemos destacar: 
linfopenia, baixos números de linfócitos $\mathrm{CD} 4+$, resposta in vitro diminuída ao estímulo por fitohemaglutinina, produção diminuída de citocinas (IL-2, IL-4, IL-5, IL10) e ausência de reação de hipersensibilidade tardia (Kruger 1984; Spickett 1990; Spickett 1992; Funauchi 1995; Kondratenko 1997).

A interação cognata entre linfócitos T e B também pode estar prejudicada em pacientes com CVID. Esta interação ocorre nos centros germinativos e induz a troca de classes de imunoglobulinas e a hipermutação somática, eventos essenciais no processo de maturação de linfócitos B e geração de plasmócitos (Salzer 2006a). A molécula inducible costimulator (ICOS) presente nos linfócitos T interage com o seu ligante (ICOSL) nos linfócitos B promovendo a troca de isotipo e a diferenciação terminal destas em linfócitos B de memória ou plasmócitos. Mutações no gene desta molécula é uma causa rara de CVID (Salzer 2004). Neste mesmo contexto de interação entre linfócitos $T$ e $B$, foram descritos pacientes com CVID que apresentavam expressão diminuída de CD40L nos linfócitos $T$ e conseqüente prejuízo na interação com o CD40 nos linfócitos B. A ausência ou diminuição da interação entre as moléculas CD40 e CD40L prejudica a proliferação e diferenciação dos linfócitos B nestes pacientes (Farrington 1994).

Apesar da descrição de vários casos de pacientes com CVID apresentando deficiências em outras células que não os linfócitos $B$, estes constituem o grupo celular comprometido com maior freqüência nos pacientes com CVID. Muitos pacientes apresentam linfócitos B circulantes, mas em número absoluto freqüentemente reduzido como reflexo de um grau variável de linfopenia (Guo 1995; Kondratenko 1997).

A ausência ou diminuição de linfócitos B de memória relatada em pacientes com CVID também pode contribuir para o fenótipo da doença já que um estímulo 
antigênico secundário induz uma expansão clonal rápida e maciça de linfócitos $B$ de memória, gerando oito a dez vezes mais plasmócitos em relação a uma resposta primária (McHeyzer-Williams 1999; Agematsu 2002).

Pacientes com poucos linfócitos $\mathrm{B}$ de memória $\operatorname{lgM}^{+} \lg ^{+} \mathrm{CD}_{2} 7^{+}$apresentam uma taxa aumentada de infecções por Streptococcus pneumoniae e não são capazes de responder a vacinação, resultando em um dano pulmonar progressivo (Carsetti 2005). Estas células representam uma população de linfócitos B recirculantes da zona marginal esplênica e dispõem de um repertório de anticorpos pré-diversificados para eliminar bactérias encapsuladas de forma independente de linfócitos T (Weller 2004). A investigação das subpopulações de linfócitos B em pacientes esplenectomizados revelou uma redução grave ou ausência da população de linfócitos $B \operatorname{lgM}^{+} \lg \mathrm{D}^{+} \mathrm{CD} 27^{+}$, correlacionando com a susceptibilidade aumentada a infecções por bactérias encapsuladas nestes pacientes (Kruetzmann 2003).

A diferenciação terminal dependente de antígeno dos linfócitos B em células secretoras de anticorpos também pode estar comprometida em indivíduos com CVID. Vários estudos relataram a existência de pacientes com números normais de linfócitos B no sangue periférico, mas que não se diferenciam em plasmócitos e são incapazes de produzir imunoglobulinas em quantidades que se equiparem àquelas encontradas nos soros de indivíduos normais (Saxon 1992; Buckley 2004; Castigli 2005; Salzer 2005; Salzer 2006a).

Com base nestas evidências, tornou-se natural o interesse em investigar as vias de sinalização envolvidas nesta diferenciação terminal e possíveis defeitos que poderiam prejudicar a produção de imunoglobulinas em pacientes com CVID. Postulando que a expressão defeituosa de proteínas essenciais neste processo de diferenciação poderia ser a responsável pelos aspectos fenotípicos observados na 
CVID, pesquisadores analisaram a expressão de moléculas envolvidas na proliferação de linfócitos B e na diferenciação terminal destas células.

O desenvolvimento e manutenção da imunidade humoral dependem, dentre outros fatores, da interação funcional das moléculas B cell-activating factor of the TNF family (BAFF) e $\boldsymbol{A}$ proliferation-inducing ligand (APRIL) com os membros da superfamília de receptores do fator de necrose tumoral (TNF): $\boldsymbol{B}$ cell-activating factor receptor (BAFFR), transmembrane activator and calcium-modulator and cyclophilin ligand interactor (TACI) e $\boldsymbol{B}$ cell maturation protein $\boldsymbol{A}$ (BCMA). As moléculas BAFF e APRIL, expressas em células dendríticas e macrófagos, interagem com os receptores BAFFR e TACl expressas em linfócitos B e são essenciais na indução de troca de isotipo independente da interação entre CD40 e CD40L. Com base nestes dados, pacientes com CVID foram analisados quanto à presença de mutações no gene TNFRSF13B, codificador da proteína TACl. Foram identificadas mutações neste gene em aproximadamente $10 \%$ dos pacientes e verificou-se que estes pacientes apresentavam números normais de linfócitos $B$ no sangue periférico embora apresentassem números reduzidos de linfócitos $B$ de memória, principalmente na subpopulação de linfócitos B que sofreram troca de isotipo (Castigli 2005; Salzer 2005).

Mutações em outras proteínas também foram descritas, como por exemplo, no gene da molécula CD19 de linfócitos B de pacientes com CVID. As moléculas CD19 e CD21 facilitam o reconhecimento de complexos antígeno-anticorpo pelo receptor de linfócitos $\mathrm{B}(\mathrm{BCR}-\boldsymbol{B}$ cell receptor). As mutações levam a ausência ou redução drástica da expressão da proteína CD19 na superfície de linfócitos B acarretando também uma redução concomitante da expressão de CD21. A deficiência na expressão destas moléculas prejudica o influxo de cálcio após o 
estímulo via BCR gerando uma diminuição de linfócitos B de memória nos pacientes com CVID (van Zelm 2006).

Outro grupo investigou a expressão de moléculas envolvidas no controle do ciclo celular, pois a diferenciação em plasmócitos exige a interrupção no ciclo celular dos linfócitos B. Para este fim, foram utilizados linfonodos de cinco pacientes com CVID e observou-se que o centro germinativo dos linfonodos apresentava-se hiperplásico e grande parte das células deste centro germinativo expressavam o fator de transcrição B cell leukemia/lymphoma-6 (BCL-6), essencial para a proliferação dos linfócitos B do centro germinativo. A proteína BCL-6 inibe a expressão de genes envolvidos no controle do ciclo celular, ativação de linfócitos B e diferenciação destas células mantendo, desta forma, uma proliferação rápida e intensa dos linfócitos B do centro germinativo enquanto a diferenciação terminal em plasmócitos fica prejudicada. Os autores também verificaram a expressão da proteína B lymphocyte inducer of maturation program-1 (Blimp-1), uma proteína reguladora essencial na formação de plasmócitos. Interessantemente, a expressão de Blimp-1 encontrava-se em níveis considerados normais e cogitou-se a possibilidade do envolvimento de outros genes downstream na diferenciação insatisfatória de linfócitos B em plasmócitos (Taubenheim 2005).

Além de Blimp-1, também é indispensável a expressão de fatores de transcrição desencadeados pelo aumento da síntese de imunoglobulinas na diferenciação terminal de linfócitos B. O aumento na tradução de cadeias nascentes de imunoglobulinas causa estresse do retículo endoplasmático (RE) e expansão desta organela, além de desencadear uma via de sinalização intracelular chamada Unfolded Protein Response (UPR). Esta via age no sentido de resgatar a 
homeostasia do retículo mantendo o equilíbrio entre a capacidade de processamento e a demanda fisiológica da organela (Iwakoshi 2003a).

\subsection{Estresse do RE e via UPR}

Todas as proteínas recém sintetizadas precisam ser dobradas de forma apropriada. Nas células eucarióticas, a maioria das proteínas de membrana ou secretadas entram em uma via secretora e são translocadas para o RE (Bross 2003).

O RE apresenta um ambiente ótimo e único para o processamento em larga escala de cadeias polipeptídicas. Comparado ao citosol, o RE é um ambiente oxidante que facilita a formação de pontes dissulfídicas nas proteínas em maturação permitindo a estabilização da estrutura protéica. Estima-se que a concentração de proteínas no lúmen do $\mathrm{RE}$ seja da ordem de $100 \mathrm{mg} / \mathrm{ml}$, o que exige um monitoramento meticuloso para evitar que proteínas mal-dobradas ou não dobradas sejam secretadas (Brooks 1999; Wu 2006).

As proteínas entram no RE como cadeias polipeptídicas não dobradas e se dobram no lúmen da organela. O dobramento das proteínas é facilitado por chaperonas residentes no RE (Turner 2000). Elas promovem o dobramento por meio de ciclos de ligação e liberação do substrato (cadeias polipeptídicas) regulados pela hidrólise do ATP em ADP (Barral 2004). A chaperona binding protein (BiP) é a principal reguladora da atividade de dobramento do RE. Ela é um membro da família das proteínas de choque térmico Hsp70 e apresenta dois domínios funcionais principais: uma porção N-terminal ATPase e outra C-terminal de ligação a peptídeos (Hendershot 2004). 
A quantidade de proteínas depositadas no RE varia entre os tipos celulares e durante a vida da célula. O desenvolvimento da célula, progressão do ciclo celular e mudanças no ambiente celular podem afetar a quantidade e o tipo de proteínas que precisam ser dobradas no RE. Por isso, a célula, durante a sua vida, freqüentemente encontra situações em que o RE necessita de uma capacidade de dobramento aumentada resultando em estresse. O estresse do RE pode ser transitório quando um programa de expressão gênica está alterado em resposta a mudanças dos sinais extracelulares ou pode ser permanente em células que apresentam mutações que interferem na maturação apropriada de proteínas secretadas ou de membrana (Kaufman 1999; Rutkowski 2004; Zhang 2005).

O estresse do RE desencadeia a via UPR, cujo principal objetivo é aumentar a eliminação de proteínas mal-dobradas e conseqüentemente diminuir o estresse do RE (Travers 2000). Isso é feito através da indução da transcrição de componentes da maquinaria secretória, ativação da degradação de proteínas associada ao RE dependente de proteassomo (ERAD - ER-associated degradation) e controle da tradução de proteínas (Boyce 2006).

A presença de estresse é detectada por três proteínas transmembrana residentes no RE: a PERK (RNA-dependent-protein-kinase-like $E R$ ), o fator de transcrição bZIP (basic leucin-zipper) ATF6 (activating transcription factor $6-\alpha$ e $\beta$ ) e a quinase/endonuclease IRE-1 (inositol requiring enzyme 1 - $\alpha$ e $\beta$ ) (figura 2). 


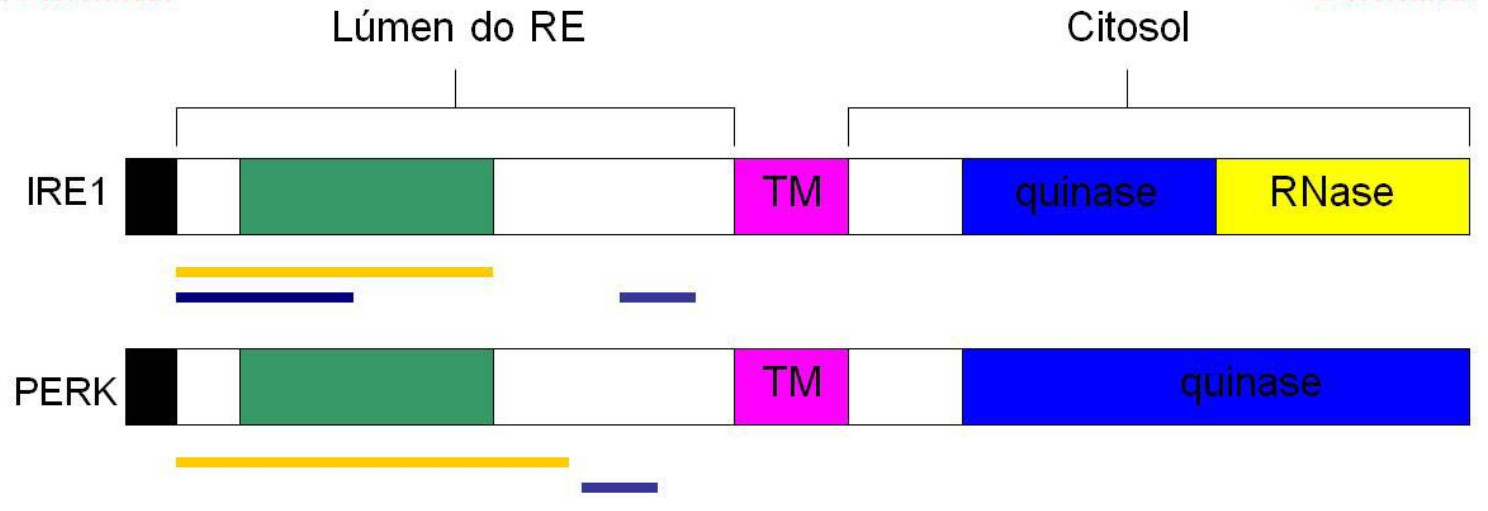

Citosol

Lúmen do RE

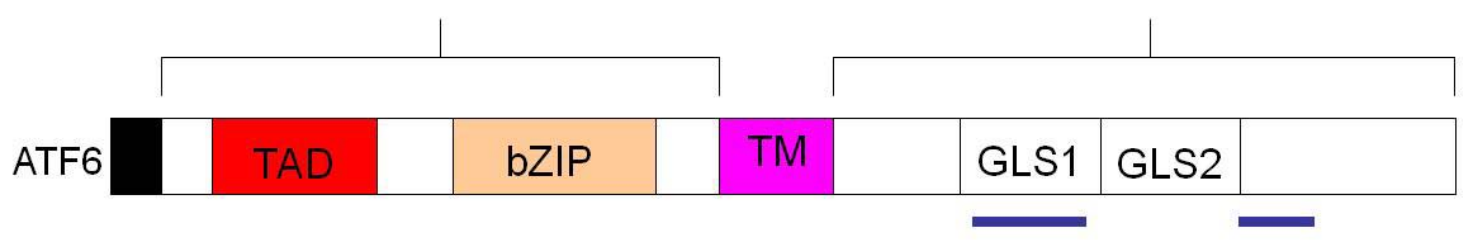

Regiões que interagem com a BiP

Região homóloga a IRE1 e PERK

Região para transdução de sinal e oligomerização

Peptídeo sinal

TAD - domínio de ativação transcricional GSL - seqüência de localização Golgi TM - domínio transmembrana

Figura 2: Sensores de estresse do retículo endoplasmático (Adaptado de Hendershot, 2004).

Os domínios luminais de IRE-1, PERK e ATF6 associam-se mais rapidamente à $\mathrm{BiP}$ do que entre si. $\mathrm{A}$ BiP está presente em altas concentrações no lúmen do $\mathrm{RE}$ e se associa preferencialmente à proteínas não dobradas. Assim, quando ocorre acúmulo de proteínas não dobradas, a BiP se desliga de IRE-1, ATF6 e PERK. Por sua vez, IRE-1 e PERK, quando livres, sofrem homodimerização e se autofosforilam enquanto ATF6 migra para o complexo de Golgi e sofre clivagem proteolítica (Rutkowski 2004) (figura 3). 


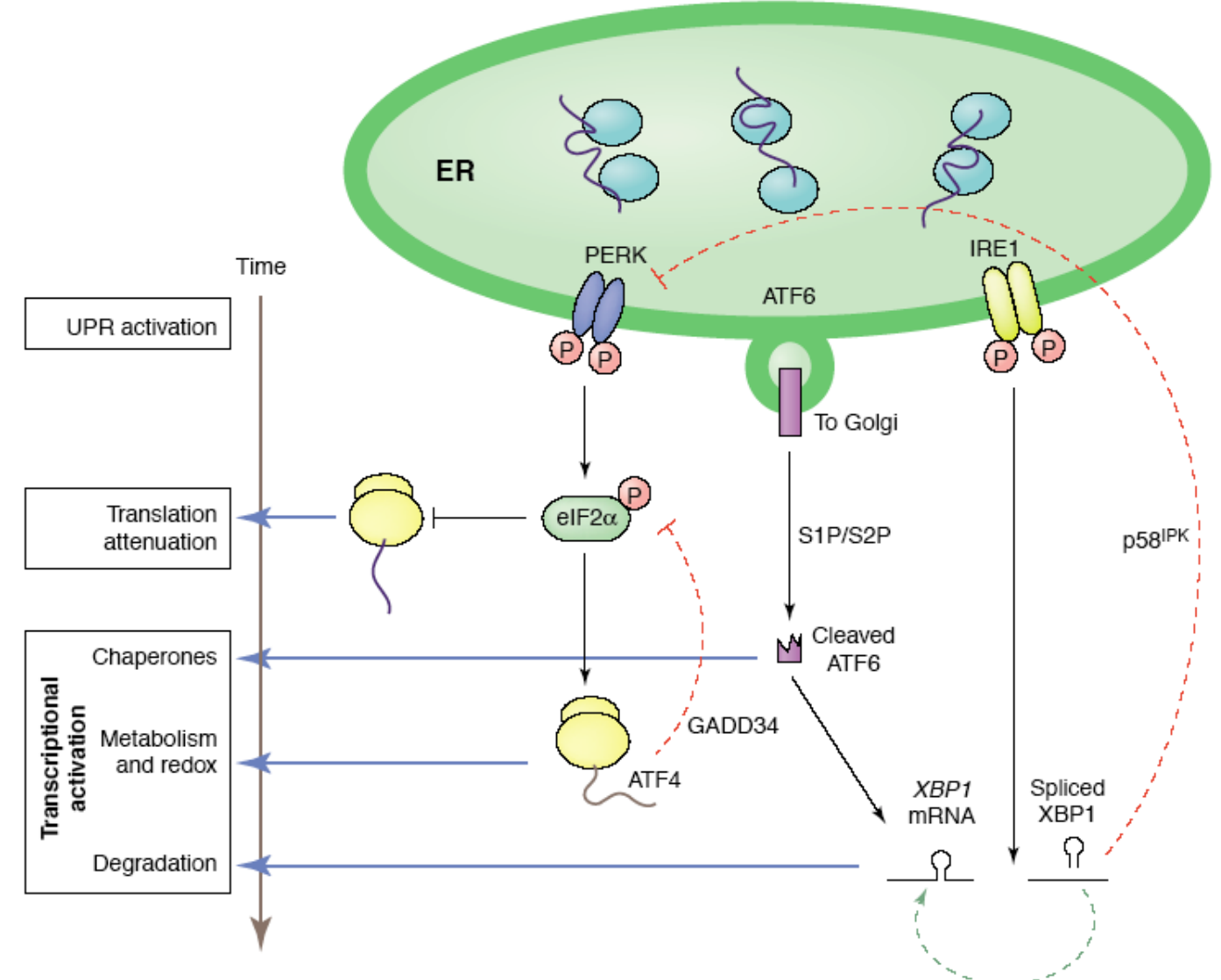

Figura 3: Componentes distintos da via UPR mediados por cada sensor residente no retículo endoplasmático. Alterações na cinética de ativação de cada via da UPR, combinadas com feedback positivo ou negativo, geram aspectos distintos da resposta de cada sensor. A ativação completa da via IRE-1 $\alpha$ requer a expressão aumentada de RNAm XBP-1 induzida por ATF6, resultando na transcrição de genes downstream ao ATF6 antes de ocorrer a transcrição dos genes downstream ao XBP-1. As setas pontilhadas representam feedbacks positivo (verde) e negativo (vermelho). Deve-se enfatizar que as funções de PERK, ATF6 e IRE-1 $\alpha$ provavelmente não são mutuamente exclusivas como mostrado aqui, e alguns genes necessitam da ação de mais de uma das vias sensoriais para serem ativados (Rutkowski 2004).

A PERK é uma proteína serina/treonina quinase transmembrana transdutora de sinal do RE. Uma vez ativada, ela fosforila a subunidade $\alpha$ do fator de iniciação da tradução 2 (elF2 $\alpha$ - eukaryotic initiation factor-2 $\alpha$ ) resultando na diminuição da tradução da maioria dos RNAm. Essa tradução atenuada alivia a sobrecarga do RE por reduzir o tráfego de polipeptídeos recém-sintetizados na organela (Harding 1999). A fosforilação de elF2 $\alpha$ e a repressão da tradução completam-se em 30 minutos após a exposição ao estresse (Rutkowski 2004). 
A desregulação da via UPR associada à Imunodeficiência Comum Variável Juliana Sayuri Kuribayashi

No entanto, existem fatores como o activating transcription factor 4 (ATF4), membro da família CREB (cAMP response-element-binding) de fatores de transcrição, que requerem a fosforilação de elF2 $\alpha$ para a sua tradução. O ATF4 é essencial para induzir a transcrição da molécula growth-arrest DNA-damage gene 34 (GADD 34), uma proteína citosólica que se associa à proteína fosfatase 1 (PP1) para desfosforilar elF $2 \alpha$, iniciando uma alça regulatória que recomeça a síntese protéica algumas horas após a indução do estresse (Boyce 2006).

O ATF4 também induz a síntese do fator C/EBP homologous protein (CHOP) uma proteína homóloga à proteína de ligação ao acentuador CCAAT (C/EBP CCAAT enhancer binding protein). A molécula CHOP é um fator de transcrição relacionado à apoptose das células expostas ao estresse crônico do RE. Dessa forma, a sinalização via ATF4 age restabelecendo a atividade normal do retículo por induzir o reinício da síntese protéica desfosforilando elF2 $\alpha$ e pode acarretar apoptose via CHOP quando o reinício da síntese protéica leva novamente ao estresse do RE. Portanto, a sinalização mediada por PERK abrange diversas finalidades, permitindo à UPR influenciar vários aspectos do metabolismo celular, homeostase do RE e até mesmo a sobrevivência ou morte da célula (Gass 2004).

O ATF6 é um fator de transcrição que contém um domínio bZIP no citosol e um domínio sensor de estresse no lúmen do RE. Após ser liberado da BiP e migrar para o complexo de Golgi, o ATF6 é clivado pelas proteases sítio 1 e sítio 2 (SP1 e SP2). Seu domínio bZIP N-terminal é liberado da membrana do complexo de Golgi após a clivagem e entra no núcleo para ativar a transcrição de $\mathrm{CHOP}$, do fator $\boldsymbol{X}$ box binding protein 1 (XBP-1), chaperonas do RE e outros genes envolvidos com a resolução da UPR (Yoshida 2000; Zhang 2006). A importância do fator ATF6 na UPR de mamíferos foi confirmada pela observação de que células da linhagem 
HeLa mutantes sem o domínio de ativação de ATF6 exibem um efeito dominante negativo na indução dos genes alvos da UPR (Yoshida 2000).

A importância da sinalização mediada por ATF6 na produção adequada de anticorpos por plasmócitos foi mostrada a partir da expressão forçada de um dominante negativo de ATF6 mutante em linfócitos B. A expressão do dominante negativo não diminui a diferenciação dos linfócitos B em plasmócitos secretores de anticorpos, mas reduziu a secreção de $\lg M$ e aumentou a liberação inapropriada de fragmentos intermediários de IgM comprometendo o controle de qualidade da biossíntese de IgM (Gunn 2004).

A IRE-1 é uma proteína transmembrana cujo domínio amino-terminal se localiza no lúmen do RE e a porção carboxi-terminal se estende pelo citoplasma ou nucleoplasma. A porção C-terminal é composta por um domínio serina/treonina proteína quinase e um domínio endonuclease (RNase) sítio-específico. Existem dois homólogos do gene ire1, ire $1 \alpha$ e ire $1 \beta$, em mamíferos. Enquanto ire $1 \alpha$ é expresso na maioria das células e tecidos, a expressão de ire $1 \beta$ está primariamente restrita às células epiteliais intestinais (Yoshida 2001). O domínio citoplasmático da IRE-1 ativada pode recrutar a proteína adaptadora TNF receptor-associated factor 2 (TRAF2), que por sua vez recruta e ativa a caspase-12, um indutor de apoptose específico para o estresse do RE (Nakagawa 2000; Urano 2000; Brewer 2005).

Quando liberada da BiP, a IRE-1 $\alpha$ forma dímeros e sofre trans-autofosforilação e ativa seu domínio endonuclease. O RNAm de XBP-1 é o substrato para o domínio endonuclease da IRE-1 $\alpha$ e é expresso em baixos níveis nas células não estressadas. A síntese de RNAm de XBP-1 é induzida pelo ATF6 como uma conseqüência do estresse do RE (Lee 2002). Portanto, quantidades substanciais de 
RNAm de XBP-1 só podem ser geradas após as vias dependentes de PERK e ATF6 já terem sido ativadas (Yoshida 2003).

O XBP-1 é um membro da família CREB/ATF de fatores de transcrição que foi inicialmente isolado por causa da sua habilidade de se ligar a uma seqüência do elemento responsivo ao AMP cíclico (CRE) no gene codificador da molécula Dra do complexo principal de histocompatibilidade de classe II (MHC II - major histocompatibility complex class II). A expressão de XBP-1 é ubíqua, sendo encontrado em fígado, rins, cérebro, entre outros (Clauss 1993).

O XBP-1 é o principal fator de transcrição que induz a expressão dos genes alvos da UPR quando está na sua forma ativa. O mesmo é composto por uma porção N-terminal bZIP contendo um domínio de ligação ao DNA e uma porção Cterminal com o domínio de ativação da transcrição (Yoshida 2001).

A IRE-1 $\alpha$ ativada faz uma clivagem sítio-específica no RNAm de XBP-1 (figura 4). Um íntron de 26 nucleotídeos é excisado e um mecanismo indefinido religa os fragmentos 5' e 3', produzindo um RNAm XBP-1 spliced com a fase de leitura (reading frame) alterada (Quadro 1). 


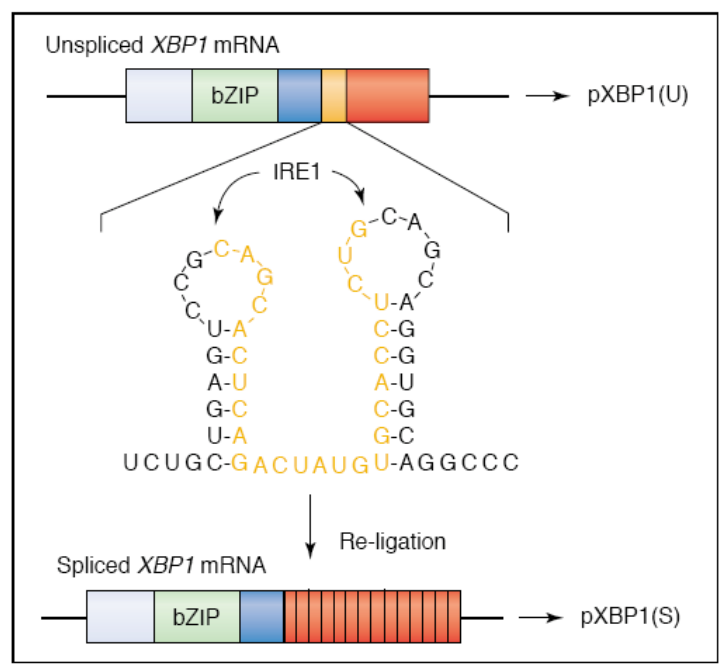

Figura 4: Splicing do RNAm XBP-1 mediado pela via UPR. O RNAm unspliced humano codifica um fator de transcrição de 261 aminoácidos, pXBP-1u. A figura mostra a estrutura secundária do RNAm XBP-1 com a seqüência de 26 nucleotídeos (em amarelo) excisada pela IRE-1; as setas indicam os sítios de clivagem. A re-ligação do RNAm clivado gera um RNAm com a fase de leitura alterada, resultando na transcrição de um fator de transcrição de 376 aminoácidos, pXBP-1s. A seqüência de aminoácidos da região C-terminal (vermelho) é alterada (vermelho riscado), estabilizando o fator e aumentando sua capacidade de ativador da transcrição (Gass 2004).

O splicing gera uma proteína com um domínio C-terminal de 226 aminoácidos enquanto a proteína unspliced apresenta um domínio C-terminal de 105 aminoácidos (Yoshida 2001; Calfon 2002). Essa alteração da fase aberta de leitura (ORF - open reading frame) resulta na síntese de uma proteína de 376 aminoácidos enquanto uma proteína de 261 aminoácidos é sintetizada a partir do RNAm unspliced (Lee 2003b). A forma spliced apresenta o domínio N-terminal original de ligação ao DNA e mais um domínio adicional de transativação na porção C-terminal (Iwakoshi 2003a) (Quadro 2). 
Quadro 1 - Seqüência de nucleotídeos que codificam o XBP-1 spliced e unspliced (gi: 14110394)

Seqüência de nucleotídeos que codificam o XBP-1

ATGGTGGTGGTGGCAGCCGCGCCGAACCCGGCCGACGGGACCCCTAAAGTTCTGCTTCTGT CGGGGCAGCCCGCCTCCGCCGCCGGAGCCCCGGCCGGCCAGGCCCTGCCGCTCATGGTGCC AGCCCAGAGAGGGGCCAGCCCGGAGGCAGCGAGCGGGGGGCTGCCCCAGGCGCGCAAGCGA CAGCGCCTCACGCACCTGAGCCCCGAGGAGAAGGCGCTGAGGAGGAAACTGAAAAACAGAG TAGCAGCTCAGACTGCCAGAGATCGAAAGAAGGCTCGAATGAGTGAGCTGGAACAGCAAGT GGTAGATTTAGAAGAAGAGAACCAAAAACTTTTGCTAGAAAATCAGCTTTTACGAGAGAAA ACTCATGGCCTTGTAGTTGAGAACCAGGAGTTAAGACAGCGCTTGGGGATGGATGCCCTGG TTGCTGAAGAGGAGGCGGAAGCCAAGGGGAATGAAGTGAGGCCAGTGGCCGGGTCTGCTGA GTCCGCAGCACTCAGACTACGTGCACCTCTGCAGCAGGTGCAGGCCCAGTTGTCACCCCTC CAGAACATCTCCCCATGGATTCTGGCGGTATTGACTCTTCAGATTCAGAGTCTGATATCCT GTTGGGCATTCTGGACAACTTGGACCCAGTCATGTTCTTCAAATGCCCTTCCCCAGAGCCT GCCAGCCTGGAGGAGCTCCCAGAGGTCTACCCAGAAGGACCCAGTTCCTTACCAGCCTCCC TTTCTCTGTCAGTGGGGACGTCATCAGCCAAGCTGGAAGCCATTAATGAACTAATTCGTTT TGACCACATATATACCAAGCCCCTAGTCTTAGAGATACCCTCTGAGACAGAGAGCCAAGCT AATGTGGTAGTGAAAATCGAGGAAGCACCTCTCAGCCCCTCAGAGAATGATCACCCTGAAT TCATTGTCTCAGTGAAGGAAGAACCTGTAGAAGATGACCTCGTTCCGGAGCTGGGTATCTC AAATCTGCTTTCATCCAGCCACTGCCCAAAGCCATCTTCCTGCCTACTGGATGCTTACAGT GACTGTGGATACGGGGGTTCCCTTTCCCCATTCAGTGACATGTCCTCTCTGCTTGGTGTAA ACCATTCTTGGGAGGACACTTTTGCCAATGAACTCTTTCCCCAGCTGATTAGTGTCTAA

26 nucleotídeos excisionados no splicing alternativo códon de parada da forma unspliced códon de parada da forma spliced 
Quadro 2 - Seqüência dos aminoácidos das proteínas XBP-1 spliced e unspliced (gi: 14110394)

\begin{abstract}
Proteína unspliced
MVVVAAAPNPADGTP KVLLLSGQPASAAGAPAGQALP LMVPAQRGASPEAASGGLPQAR KRQRLTHLSPEEKALRRKLKNRVAAQTARDRKKARMSELEQQVVDLEEENQKLLLENQL LREKTHGLVVENQELRQRLGMDALVAEEEAEAKGNEVRPVAGSAESAALRLRAP LQQVQ AQLSP LQNI SPWILAVLTLQIQSLISCWAFWTTWTQSCS SNALPQSLPAWRS SQRSTQK DPVPYQPPF LCQWGRHQP SWKP LMN
\end{abstract}

\title{
Proteína spliced
}

MVVVAAAPNPADGTP KVLLLSGQPASAAGAPAGQALP LMVPAQRGASPEAASGGLPQAR KRQRLTHLSP EEKALRRKLKNRVAAQTARDRKKARMSELEQQVVDLEEENQKLLLENQL LREKTHGLVVENQELRQRLGMDALVAEEEAEAKGNEVRPVAGSAESAAGAGPVVTPPEH LPMD SGGIDS SDSESD ILLGILDNLDPVMFFKCP SPEPASLEELPEVYPEGP S SLPASL SLSVGTSSAKLEAINELIRFDHIYTKP LVLEIPSETESQANVVVKIEEAPLSP SENDHP EF IVSVKEEPVEDDLVPELGISNLLSSSHCPKP SSCLLDAYSDCGYGGSLSPF SDMSSL LGVNHSWEDTFANELFPQLISV

Em rosa e azul: regiões C-terminais diferentes nas proteínas unspliced e spliced.

O segmento N-terminal de XBP-1 é compartilhado pelas formas spliced e unspliced e desta forma, a última exerce uma atividade dominante negativa nos genes ativados pela forma spliced. Isso ocorre por causa da competição direta entre as duas formas pelos sítios disponíveis de ligação ao DNA (Lee 2003a).

As formas spliced e unspliced são representadas por proteínas de peso aproximado de 60 e 30 kDa, respectivamente, na análise por Western-Blot. A presença da banda de $60 \mathrm{kDa}$ reflete a ativação da via UPR (Yoshida 2001). Os transcritos do XBP-1 unspliced e spliced codificam os fatores de transcrição pXBP1u e pXBP-1s, respectivamente. O fator pXBP-1s apresenta capacidade de transativação aumentada e maior estabilidade quando comparado ao pXBP-1u (Gass 2004).

O XBP-1 spliced liga-se a um elemento responsivo ao estresse do RE (ERSE - ER stress element response) ativando a transcrição de chaperonas e liga-se 
também a um elemento responsivo a proteínas não-dobradas (UPRE - unfolded protein response element) para induzir a transcrição de outros genes relacionados à degradação protéica associada ao RE (Yoshida 2003; Yoshida 2006). Dessa forma, o XBP-1s induz a transcrição de genes essenciais para a resolução do estresse do RE como aqueles que codificam chaperonas, proteínas que participam do tráfego RE - complexo de Golgi e componentes da maquinaria de degradação protéica (Travers 2000).

O XBP-1u é sintetizado constitutivamente, mas é uma proteína instável e eliminada rapidamente por degradação via proteassomo, sua taxa de degradação aproxima-se à taxa de síntese. Uma vez que o RNAm de XBP-1 sofre splicing, a proteína codificada ganha estabilidade e é capaz de induzir a transcrição gênica (Lee 2003a; Tirosh 2005b). Verificou-se que os inibidores de proteassomo estabilizam a expressão da proteína XBP-1u que por sua vez age como dominante negativo ao inibir a atividade da forma spliced. Utilizando esses inibidores, observouse que a ausência de XBP-1 funcional (spliced) aumenta a apoptose induzida por estresse do RE em células de mieloma (Lee 2003a).

\subsection{XBP-1 e diferenciação de plasmócitos}

O XBP-1 é o único fator de transcrição considerado essencial para a diferenciação em plasmócitos. Os sinais para diferenciação destas células e desencadeamento da via UPR cooperam para induzir a expressão do RNAm de $\mathrm{XBP}-1$ e o splicing do transcrito. A atividade da IRE-1 $\alpha$, gerando a forma ativa do XBP-1, e a ativação da via UPR ocorrem como um mecanismo do RE para suportar a produção de grandes quantidades de anticorpos (Iwakoshi 2003a) (figura 5). 


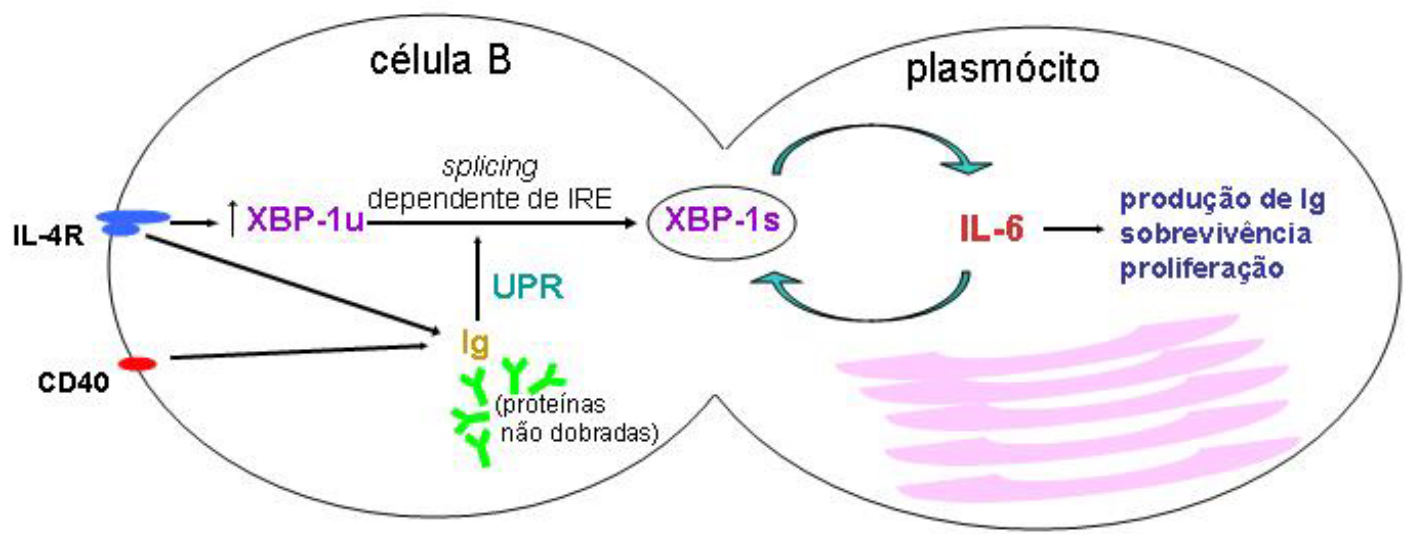

Figura 5: Modelo de ativação da via UPR na diferenciação terminal de linfócitos $B$ em plasmócitos. Os linfócitos B ativados rapidamente aumentam a transcrição de RNAm XBP-1 unspliced após a sinalização via IL-4 e sinais para a diferenciação de linfócitos B como CD40, resultando na produção de imunoglobulinas. A presença de proteínas não dobradas estimula o splicing do XBP-1 mediado pela IRE-1 $\alpha$. A proteína spliced resultante media a ativação da via UPR para que o retículo endoplasmático possa suportar a produção aumentada de anticorpos. O crescimento e sobrevivência do plasmócito são mantidos pela produção de IL-6 induzida por XBP-1 spliced por meio de uma alça auto-reguladora entre XBP-1 e IL-6. Adaptado de Iwakoshi 2003b.

O papel de XBP-1 na diferenciação dos linfócitos B foi estudado através da geração de camundongos quimeras $\mathrm{RAG}^{-/-}$contendo células linfóides $\mathrm{XBP}-1^{-/-}$. Os linfócitos B destes camundongos quiméricos mostraram-se menos diferenciados, pois apresentaram uma expressão aumentada de c-Myc - myelocytomatosis oncogene (que é reprimido nos plasmócitos) e menor expressão da cadeia $\mathrm{J}$ de imunoglobulinas necessária para a geração de plasmócitos secretores de $\lg M$ e $\lg \mathrm{A}$. A reintrodução de XBP-1 nas células, in vitro, induziu proliferação, mudança de classe de imunoglobulinas, expressão de moléculas de superfície e secreção normal de citocinas, demonstrando, desta maneira, que o XBP-1 é essencial para a formação dos plasmócitos. Endossando estes resultados, não se encontrou plasmócitos nos tecidos linfóides dos camundongos $\mathrm{RAG}^{-/} \mathrm{XBP}-1^{-/-}$previamente imunizados. Conseqüentemente, esses animais secretavam baixos níveis de 
imunoglobulinas e não eram capazes de controlar a infecção pelo vírus polioma, resposta dependente de linfócitos B (Reimold 2001).

Além disso, o XBP-1 apresenta um papel adicional na diferenciação de plasmócitos porque a forma spliced induz a produção de IL-6, uma citocina essencial para a diferenciação de plasmócitos (Iwakoshi 2003a).

A presença de transcritos de XBP-1 em níveis aumentados foi detectada em plasmócitos infiltrantes em quadros de doenças inflamatórias como a artrite reumatóide. Adicionalmente, níveis elevados de XBP-1 foram relatados em culturas primárias de linfócitos B murinos estimulados com anti-CD40 ou LPS em várias linhagens de células de mieloma. A diferenciação de plasmócitos é induzida, tanto in vivo quanto in vitro, por citocinas como IL-2, IL-4, IL-5, IL-6, IL-10 e IL-13 (Reimold 2001).

Inicialmente acreditava-se que, durante a diferenciação de plasmócitos, a produção aumentada de Ig induzia a UPR pelos mecanismos clássicos (Ma 2003). No entanto, atualmente considera-se que, ao contrário do que ocorre nas UPRs induzidas farmacologicamente, a ativação dessa via na diferenciação de linfócitos B possa ocorrer por um mecanismo independente do estresse do RE (Gass 2002; van Anken 2003; Iwakoshi 2003a).

Para demonstrar que o splicing do XBP-1 em linfócitos B diferenciados é dependente da ativação da via UPR, criou-se populações de linfócitos B apresentando IgM de superfície ou não (com ausência completa de cadeias pesadas de IgM intracelulares). Essas populações foram obtidas de uma linhagem murina cujo gene da região variável da cadeia pesada B1-8 é flanqueado pelo sítio loxP, permitindo que ele seja deletado através de uma recombinação mediada pela recombinase Cre. Os linfócitos B desse camundongo desenvolvem normalmente in 
vivo; mas, após ativação da recombinase Cre, os linfócitos $\mathrm{B}$ ex vivo de $\mathrm{B} 1-\mathrm{8}^{\mathrm{f} /+}$ não produzem cadeias pesadas de imunoglobulinas. As células foram separadas por citometria de fluxo quanto a expressão de $\lg M$ de superfície e as populações foram analisadas quanto a produção de XBP-1s. Verificou-se que na ausência de $\lg M$ a produção de XBP-1s é diminuída, evidenciando que o acúmulo de cadeias pesadas de Ig induz a ativação de IRE-1 $\alpha$ (Iwakoshi 2003a).

\subsection{XBP-1 e CVID}

O fator de transcrição XBP-1 é essencial na diferenciação terminal de linfócitos B. Podemos postular que um desbalanço entre as formas spliced e unspliced poderia contribuir para o fenótipo da CVID. Este desbalanço poderia ser ocasionado pela estabilização da forma unspliced, por defeito no processamento do RNAm do XBP-1 (aumentando o número de cópias da forma unspliced), pela atividade comprometida da IRE-1, pela ausência ou diminuição das citocinas envolvidas na geração de plasmócitos ou até mesmo por falhas na interação entre linfócitos T e B. 


\section{OBJETIVOS}

1. Identificar pacientes com CVID com desregulação da via UPR - expressão alterada de XBP-1.

2. Analisar o fenótipo das células mononucleares periféricas dos pacientes com expressão alterada de XBP-1.

3. Seqüenciar os genes xbp1 e ire1a dos pacientes com expressão alterada de XBP-1 - identificação de mutações.

4. Verificar se a expressão alterada de XBP-1 é uma disfunção intrínseca da célula B dos pacientes por meio de ensaios de estresse celular. 


\section{MATERIAL E MÉTODOS}

\subsection{Pacientes}

Os pacientes envolvidos no projeto foram diagnosticados como portadores da Imunodeficiência Comum Variável segundo critérios estabelecidos pelo Pan American Group for Immunodeficiencies (www.pagid.de). O tratamento médico está sob responsabilidade dos doutores Luiz Vicente Rizzo, Cristina Kokron e Myrthes Toledo Barros (Hospital das Clínicas, Faculdade de Medicina, Universidade de São Paulo).

O sangue foi coletado no laboratório de Imunologia Clínica e Alergia da Faculdade de Medicina da Universidade de São Paulo mediante a autorização do paciente através do Termo de Consentimento Livre e Esclarecido. O protocolo para obtenção do sangue dos pacientes com CVID e sua utilização nestes estudos foi aprovado pela Comissão de Ética em Pesquisas com Seres Humanos do Instituto de Ciências Biomédicas - USP (parecer 669/CEP).

Os critérios para incluir um paciente no projeto de pesquisa foram: diagnóstico de CVID, ter mais de 18 anos e não ser portador de HIV ou hepatite C. Todos os pacientes, que concordaram em participar, foram incluídos no projeto.

\subsection{Isolamento das células mononucleares do sangue periférico}

Células mononucleares de sangue periférico (PBMCs - peripheric mononuclear blood cells) foram obtidas de doadores saudáveis ou portadores de CVID por centrifugação em gradiente Ficoll-Paque (GE Healthcare - Uppsala, 
Suécia). Após centrifugação a $900 x g$ por 30 minutos a $20^{\circ} \mathrm{C}$, as células mononucleares do sangue periférico foram coletadas na interface e lavadas três vezes em HBSS (Hanks' Balanced Salt Solution - Cambrex Bio Science Walkersville, MD, EUA) por meio de centrifugação a $400 x g$ por 10 minutos a $20^{\circ} \mathrm{C}$. As células foram quantificadas e a viabilidade verificada pela utilização de azul de Trypan (Cambrex Bio Science).

\subsection{Caracterização das células mononucleares do sangue periférico}

Alíquotas de $1 \times 10^{5}$ células em $500 \mu \mathrm{l}$ de PBS contendo $1 \%$ de soro bovino fetal (Invitrogen Corporation - Carlsbad, CA, EUA) e 0,1\% de azida sódica foram incubadas com anticorpos monoclonais (Kaneko) anti-CD3, anti-CD4, anti-CD5, antiCD8, anti-CD14, anti-CD16, anti-CD19, anti-CD25, anti-CD27, anti-CD45RA, antiCD45RO, anti-CD56 e anti-CD57, conjugados com fluoresceína (FITC), ficoeritrina (PE) ou CyChrome (BD Biosciences - San Jose, CA, EUA) durante 30 minutos a $4^{\circ}$ e protegido da luz. Em seguida foram efetuadas duas lavagens em PBS contendo $1 \%$ de soro bovino fetal (Invitrogen) e $0,1 \%$ de azida sódica. As células foram ressuspendidas em $500 \mu$ desta mesma solução e submetidas à análise em citômetro de fluxo (FACS Calibur - BD Biosciences). Os dados obtidos foram analisados no software FlowJo (Tree Star, Inc. - Ashland, OR, EUA).

\subsection{Separação de linfócitos B e não-B por MACS Beads}

As células mononucleares de sangue periférico foram separadas em células B e não-B (linfócitos $T$, células NK, células dendríticas, monócitos, granulócitos e 
células eritróides) utilizando MACS Beads e colunas magnéticas, conforme instruções do fabricante (Miltenyi Biotec Inc. - Auburn, CA, EUA). As células mononucleares foram ressuspendidas em tampão MACS (PBS pH 7,2 0,5\%BSA 2 mM EDTA) na concentração de $1 \times 10^{7}$ células para cada $40 \mu$ de tampão. Em seguida, adicionou-se $10 \mu \mathrm{l}$ do coquetel biotina-anticorpo (fornecido no kit) para cada $1 \times 10^{7}$ células. A reação foi incubada a $4^{\circ} \mathrm{C}$ por 10 minutos. Após a incubação, adicionou-se $30 \mu \mathrm{l}$ de tampão MACS e $20 \mu \mathrm{l}$ de micro-beads anti-biotina (fornecido no kit) e foi feita uma segunda incubação a $4^{\circ} \mathrm{C}$ por 15 minutos. Após este período, adicionou-se $2 \mathrm{ml}$ de tampão MACS para cada $1 \times 10^{7}$ células. A suspensão celular foi centrifugada a $300 \mathrm{xg}$ por 10 minutos a $4^{\circ} \mathrm{C}$, o sobrenadante foi descartado e as células foram ressuspendidas em $500 \mu \mathrm{l}$ de tampão MACS.

Em seguida a suspensão celular foi transferida para a coluna (fornecida no kit) em um campo magnético. As células eluídas constituíram a população de linfócitos $B$ enquanto a população de células não-B ficou retida na coluna. A coluna foi lavada para retirar os linfócitos B que ficaram eventualmente retidas por meio de 3 passagens de $3 \mathrm{ml}$ de tampão MACS. Em seguida as células não-B foram eluídas após a retirada da coluna do campo magnético por meio de pressão. A pureza da separação foi determinada por citometria de fluxo (FACS Calibur - BD Biosciences).

\subsection{Microscopia Confocal}

As células mononucleares do sangue periférico foram cultivadas na presença de $10 \mu \mathrm{g} / \mathrm{ml}$ de lipopolissacarídeo derivado de E. coli (LPS) (Sigma-Aldrich Co - St. Louis, $\mathrm{MO}, \mathrm{EUA})$ por $48 \mathrm{~h}$ a $37^{\circ} \mathrm{C}$ e $5 \%$ de $\mathrm{CO}_{2}$. Após este período, as células foram coletadas e centrifugadas a $300 x g$ por 10 minutos. As células foram ressuspendidas 
em PBS + $1 \%$ de albumina bovina (ICN Biomedicals, Inc. - Aurora, OH, EUA) na concentração de $1 \times 10^{5}$ células $/ \mathrm{ml}$. Volumes de 50 ou $100 \mu \mathrm{l}$ foram aplicados ao suporte específico para cytospin com lâmina acoplada e centrifugados a 600 rpm em baixa rotação por cinco minutos. As células foram fixadas com acetona (SigmaAldrich) gelada.

As lâminas foram enviadas ao laboratório do Dr. Júlio Aliberti, no Children's Hospital Medical Center, Cincinnati, EUA, onde foram feitas as marcações com antihuman-IgM-Alexa Fluor 488 (fluorescência verde) e anti-BiP/GRP78-Alexa Fluor 546 (fluorescência vermelha) e marcação nuclear com DAPI (fluorescência azul), todos da Molecular Probes (Eugene, OR, EUA). As microfotografias foram adquiridas no aumento de 400x usando Apotome Microscope System (Carl Zeiss, Inc. - Jena, Alemanha). As análises das imagens e sobreposição das fluorescências foram realizadas com o software Axiovision 4.2 (Carl Zeiss, Inc.).

\subsection{Western Blot}

Dois milhões de células foram lisadas em $100 \mu$ de tampão (50 mM Tris- $\mathrm{HCl}$, 2,5\% $\beta$-mercaptoetanol, $0,1 \%$ azul de bromofenol e $10 \%$ glicerol) suplementado com inibidores de proteases (Complete Mini Cocktail, Roche Diagnostic Co - Mannheim, Alemanha), separadas em gel de poliacrilamida 10\% desnaturante (SDS-PAGE) e transferidas para uma membrana PVDF (Polyvinylidene Fluoride - GE Healthcare) por transferência semi-seca. A proteína XBP-1 foi detectada usando anticorpos antiXBP-1 policlonal e anti-coelho-HRP (ambos da Santa Cruz Biotechnology - Santa Cruz, CA, EUA). As membranas foram ensaiadas também com anti- $\beta$-actina humana (Oncogene - San Diego, CA, EUA) como controle interno. O sistema ECL (GE 
Healthcare) foi utilizado conforme instruções do fabricante para a visualização das bandas por autorradiografia.

\subsection{Extração do RNA total}

Dois milhões de células mononucleares ou linfócitos B de sangue periférico foram precipitadas por centrifugação a 300xg por 10 minutos e ressuspendidas em $1 \mathrm{ml}$ de Trizol $囚$ (Invitrogen) em tubos de $1,7 \mathrm{ml}$, de acordo com as instruções do fabricante. Foram adicionados $200 \mu \mathrm{l}$ de clorofórmio (Amresco - Solon, OH, EUA) a cada tubo e todas as amostras foram agitadas por inversão durante 15 segundos e incubadas por 3 minutos à temperatura ambiente. Após a incubação, os tubos foram centrifugados a $12.000 \times \mathrm{xg}$ a $4^{\circ} \mathrm{C}$ por 10 minutos. As fases superiores aquosas foram recuperadas e incubadas com $500 \mu \mathrm{l}$ de isopropanol (Sigma-Aldrich) por 10 minutos a temperatura ambiente. Os tubos foram centrifugados a $12.000 \times \mathrm{xg}$ a $4^{\circ} \mathrm{C}$ por 10 minutos e os sobrenadantes foram descartados. Os precipitados foram ressuspendidos em $1 \mathrm{ml}$ de etanol $75 \%$ gelado e os tubos foram centrifugados a $7.500 x g$ por 5 minutos a $4^{\circ} \mathrm{C}$. Os RNAs precipitados foram ressuspendidos em água livre de DNase e RNase e a concentração de cada amostra foi determinada pela leitura da densidade óptica $(\lambda=260 \mathrm{~nm})$ no espectrofotômetro GeneQuant pro (GE Healthcare). As amostras de RNA foram tratadas com Deoxirribonuclease I livre de RNase (DNase I - GE Healthcare) (5 unidades de enzima para cada $1 \mu \mathrm{g}$ de RNA) no tampão da enzima (100 mM Tris- $\mathrm{HCl}, 100$ mM MgCl $2,10 \mathrm{mM}$ dithiothreitol) por 15 minutos a $37^{\circ} \mathrm{C}$. 


\subsection{Preparação do DNA complementar e reação em cadeia da polimerase} (PCR)

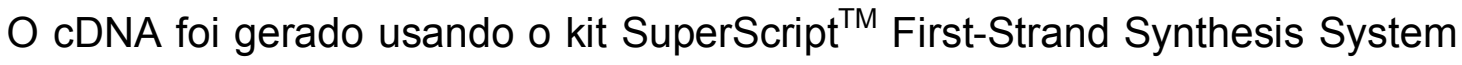
for RT-PCR (Invitrogen) e $1 \mu \mathrm{g}$ de RNA total. O RNA foi incubado com 10mM dNTPs e $0,5 \mu \mathrm{g} / \mathrm{ml}$ oligo(dT) ${ }_{12-18}$ por 5 minutos a $65^{\circ} \mathrm{C}$. Em seguida a reação foi transferida para o gelo e acrescentou-se $2 \mu$ l do tampão da enzima (200 mM Tris- $\mathrm{HCl}(\mathrm{pH} 8.4)$, $500 \mathrm{mM} \mathrm{KCl}$ ), $25 \mathrm{mM} \mathrm{MgCl}_{2}, 0,1 \mathrm{M}$ DTT (dithiothreitol) e 40 unidades de inibidor de RNase. Os tubos foram incubados a $42^{\circ} \mathrm{C}$ por 2 minutos, em seguida acrescentouse 50 unidades da transcriptase reversa SuperScript ${ }^{T M}$ /I RT a cada reação e incubou-se a $42^{\circ} \mathrm{C}$ por 50 minutos. Todos os tubos foram submetidos a uma incubação final a $70^{\circ} \mathrm{C}$ por 15 minutos para inativação da reação.

As reações de PCR foram montadas com volume final de $50 \mu$ contendo 0,8 mM dNTP mix, 1,5 mM $\mathrm{MgCl}_{2}, 0,5 \mu \mathrm{M}$ de cada oligonucleotídeo, 2,5 unidades de Taq DNA Polimerase (Invitrogen) e $2 \mu \mathrm{l}$ do cDNA sintetizado. Os cDNAs de XBP-1 total (unspliced + spliced) foram amplificados em 35 ciclos como descrito a seguir: 1 $\min$ a $94^{\circ} \mathrm{C}, 1 \mathrm{~min}$ a $50^{\circ} \mathrm{C}$ e um $1 \mathrm{~min}$ a $72^{\circ} \mathrm{C}$. Todas as reações foram submetidas a um passo final de extensão de 10 min a $72^{\circ} \mathrm{C}$ em condições não-saturadas para permitir uma análise semi-quantitativa dos diferentes produtos.

As seqüências dos oligonucleotídeos utilizados estão no Quadro 3. Os sinais dos produtos amplificados foram capturados em géis de agarose corados com brometo de etídio. 


\subsection{Reação em cadeia da polimerase (PCR) em tempo real}

Os cDNAs foram amplificados para BiP, IRE-1 e GAPDH utilizando o termociclador Mx 3005P ${ }^{\mathrm{TM}}$ QPCR Systems (Stratagene, Cedar Creek, TX, EUA). As reações foram realizadas utilizando Platinum ${ }^{\circledR}$ SYBR $^{\circledR}$ Green qPCR SuperMix-UDG (Invitrogen). Primeiramente as reações foram aquecidas a $50^{\circ} \mathrm{C}$ por 2 minutos para eliminar qualquer produto contaminante que contenha uracil e a $94^{\circ} \mathrm{C}$ por 15 minutos. Em seguida, as reações foram submetidas a 45 ciclos de amplificação como descrito a seguir: $30 \mathrm{seg}$ a $94^{\circ} \mathrm{C}, 25 \mathrm{seg}$ a $58^{\circ} \mathrm{C}$ (para GAPDH e IRE-1) ou $60^{\circ} \mathrm{C}$ (para $\mathrm{BiP}$ ) ou $53^{\circ} \mathrm{C}$ (para XBP-1s) e $30 \mathrm{seg}$ a $72^{\circ} \mathrm{C}$. Todas as reações foram submetidas a um passo final de $1 \mathrm{~min}$ a $95^{\circ} \mathrm{C}, 30 \mathrm{seg}$ a $55^{\circ} \mathrm{C}$ e 30 seg a $95^{\circ} \mathrm{C}$ para geração da curva de dissociação.

Os dados foram analisados no programa MxPro ${ }^{T M}$ QPCR Software (Stratagene). A quantificação relativa dos produtos foi calculada pelo método $2^{-\Delta \Delta C t}$ (Livak 2001) utilizando o gapdh como gene housekeeping.

As seqüências dos oligonucleotídeos utilizados estão no Quadro 3.

Quadro 3 - Oligonucleotídeos utilizados nas reações em cadeia da polimerase (PCR)

\begin{tabular}{|l|l|}
\hline Nome & 'seqüência \\
\hline F - XBP-1 total & 5'-AAACAGAGTAGCAGCTCAGACTGC-3' \\
\hline R - XBP-1 total & 5'-GTATCTCTAAGACTAGGGGCTTGGTA-3' \\
\hline R - XBP-1 unspliced & 5'-CAGAGGTGCACGTAGTCTGAGTGCTG-3' \\
\hline F - XBP-1 spliced & 5'-GAGTCCGCAGCAGGTG-3' \\
\hline R - XBP-1 spliced & 5'-GGGCTTGGTATATATGTGG-3' \\
\hline F - BiP & 5'-CGAGGAGGAGGACAAGAAGG-3' \\
\hline R - BiP & 5'-CACCTTGAACGGCAAGAACT-3' \\
\hline F - IRE-1 $\alpha$ & 5'-CGGCCTTTGCAGATAGTCTC-3' \\
\hline R - IRE-1 $\alpha$ & 5'-ACGTCCCCAGATTCACTGTC-3' \\
\hline F - GAPDH & 5'-ACCACAGTCCATGCCATCAC-3' \\
\hline R - GAPDH & 5'-TCCACCACCCTGTTGCTGTA-3'
\end{tabular}

F- forward; R - reverse 


\subsection{Seqüenciamento}

As formas spliced e unspliced do RNAm para XBP-1 foram amplificadas com os oligonucleotídeos para XBP-1 total.

A banda correspondente ao XBP-1 foi cortada do gel e, assumindo que $1 \mathrm{mg}$ de gel é equivalente a $1 \mu \mathrm{l}$, foram adicionados 2,5 volumes de $6,6 \mathrm{M}$ de iodeto de sódio (Invitrogen) à banda cortada. Após incubação a $42^{\circ} \mathrm{C}$ por 2 minutos, adicionouse 1,5 volumes de Binding Buffer (Invitrogen). A solução foi adicionada a uma coluna S.N.A.P. ${ }^{\text {TM }}$ (Invitrogen). A coluna foi centrifugada a $3000 x g$ por 30 segundos a temperatura ambiente e em seguida foi lavada com solução de etanol. O DNA foi eluído em água.

O DNA eluído foi novamente amplificado por PCR e o produto foi clonado no vetor $\mathrm{pcR}^{\circledR}-\mathrm{XL}-\mathrm{TOPO}^{\circledR}$ utilizando o kit $\mathrm{TOPO}^{\circledR} \mathrm{XL}$ PCR Cloning segundo as instruções do fabricante (Invitrogen).

A transformação de bactérias Escherichia coli quimicamente competentes foi feita de acordo com as instruções do fabricante (Invitrogen). Resumidamente, a reação contendo o inserto e o vetor $\mathrm{pcR}^{\circledR}-\mathrm{XL}-\mathrm{TOPO}{ }^{\circledR}$ foi incubada juntamente com as bactérias $E$. coli no gelo por 15 minutos e em seguida submetida a choque térmico por 30 segundos a $42^{\circ} \mathrm{C}$. Foram adicionados $250 \mu \mathrm{l}$ de meio SOC $(2 \%$ triptona, 0,5\% extrato de levedura, $10 \mathrm{mM} \mathrm{NaCl}, 2,5 \mathrm{mM} \mathrm{KCl}, 10 \mathrm{mM} \mathrm{MgCl}$, $10 \mathrm{mM}$ $\mathrm{MgSO}_{4}$ e 20 mM glicose - Invitrogen) e a reação foi submetida à agitação a 200 rpm a $37^{\circ} \mathrm{C}$ por 1 hora. Volumes diferentes da reação de transformação foram inoculados em placas contendo meio LB ágar (Invitrogen) contendo $100 \mu \mathrm{g} / \mathrm{ml}$ de ampicilina (Invitrogen). Depois de 16 horas a $37^{\circ} \mathrm{C}$, as colônias foram coletadas, transferidas 
isoladamente para tubos contendo $2 \mathrm{ml}$ de meio LB (Invitrogen) com $100 \mu \mathrm{g} / \mathrm{ml}$ de ampicilina e expandidas por 16 horas a $37^{\circ} \mathrm{C}$ sob agitação (200 rpm).

A extração do DNA plasmidial foi feita utilizando o kit Perfect Plasmid Mini, seguindo as instruções do fabricante (Eppendorf - Hamburgo, Alemanha). Tubos contendo $1,5 \mathrm{ml}$ de cultura com bactérias transformadas foram centrifugados a 12.000xg por 1 minuto para precipitar as células. O sobrenadante foi descartado, acrescentou-se $100 \mu$ de solução 1 (Glicose/Tris/EDTA) e as células foram ressuspendidas por agitação no vórtex. Em seguida acrescentou-se $100 \mu \mathrm{l}$ de solução $2(\mathrm{NaOH} / \mathrm{SDS})$ para lise bacteriana e desnaturação protéica e $100 \mu \mathrm{l}$ da solução 3 (acetato de potássio) foi adicionada para reanelar o DNA plasmidial. Os tubos foram centrifugados por 30 segundos a $14.000 x g$ e o sobrenadante foi transferido para uma coluna (fornecida no kit) juntamente com a solução DNA Binding Matrix. O DNA plasmidial permaneceu retido na matriz da coluna enquanto outras moléculas foram retiradas por centrifugação a $14.000 x g$ por 30 segundos. Em seguida acrescentou-se solução de purificação contendo etanol para lavar o DNA através de centrifugação a $14.000 x g$ por 1 minuto. O DNA plasmidial foi eluído (centrifugação a $14.000 x g$ por 1 minuto) com solução de eluição (10 mM Tris-HCl, 1 mM EDTA, pH 8.0).

A presença do inserto foi verificada em gel de agarose pela modificação do tamanho do produto em relação ao vetor vazio.

As reações de seqüenciamento foram feitas pelo Centro de Estudos do Genoma Humano (Instituto de Biologia - USP). O seqüenciamento foi feito utilizando MegaBACE 1000 (GE Healthcare) e o kit DYEnamic ET Dye Terminator (GE Healthcare). 
A desregulação da via UPR associada à Imunodeficiência Comum Variável Juliana Sayuri Kuribayashi

Os oligonucleotídeos utilizados nas reações de seqüenciamento do xbp1 foram T7 forward (5'-TAATACGACTCACTATAGGG-3') e M13 forward (5'TGTAAAACGACGGCCAGT-3') e reverse (5'-CAGGAAACAGCTATGACC-3').

Os domínios quinase e ribonuclease da IRE-1 $\alpha$ foram seqüenciados a partir do produto de PCR amplificado com os oligonucleotídeos: IRE-1 $\alpha$ quinase - sense 5'-CCTCCCTGGAACAAGACGAT-3' e antisense 5'-CTATTCTGTTCACGTCCT-3'; IRE-1 $\alpha$ ribonuclease - sense 5'-GAAGACGTCATTGCACGAGA-3' e antisense 5'AGAGGGCGTCTGGAGTCAC-3'. Estes mesmos oligonucleotídeos foram utilizados nas reações de seqüenciamento.

As seqüências foram analisadas usando o software BioEdit (Ibis Therapeutics - Carlsbad, CA, EUA) e comparadas com a seqüência de DNA depositadas no GenBank (gi: 14110394 para xbp1 e gi:37544107 para ire1a) utilizando o programa Blastn - National Center for Biotechnology Information (NCBI).

\subsection{Ensaio de estresse celular}

Um milhão de células mononucleares do sangue periférico foram cultivadas por 8 ou 12 horas em $1 \mathrm{ml}$ de meio RPMI suplementado com $10 \%$ de soro bovino fetal (Invitrogen), 1\% L-glutamina (Invitrogen), 1\% de penicilina/estreptomicina (Invitrogen) na presença de $\mu \mu \mathrm{g} / \mathrm{ml}$ de brefeldina A (BD Biosciences). Como controle, utilizamos células cultivadas com $1 \mu$ de dimetilsufóxido (DMSO - Fisher Scientific Waltham, MA, EUA). As células foram mantidas em estufa a $37^{\circ} \mathrm{C}$ e $5 \% \mathrm{CO}_{2}$. Após o período de incubação, as células foram centrifugadas a $300 x g$ por 10 minutos a temperatura ambiente e ressuspendidas em Trizol (Invitrogen) para posterior extração do RNA. 


\subsection{Ativação de linfócitos B com LPS}

Os linfócitos B imortalizados foram incubados em meio RPMI suplementado com $10 \%$ de soro bovino fetal (Invitrogen), $1 \%$ de L-glutamina (Invitrogen) $1 \%$ de penicilina/estreptomicina (Invitrogen) e $10 \mu \mathrm{g} / \mathrm{ml}$ de LPS (Invitrogen) por 48 horas. Após a incubação, o sobrenadante foi recolhido para dosagem de imunoglobulinas no sobrenadante por ELISA e as células foram utilizadas para extração de RNA e síntese de cDNA.

\subsection{ELISA}

A dosagem das imuglobulinas $\mathrm{G}$ e $\mathrm{M}$ foi feita no Hospital de Clínicas da Universidade de São Paulo por intermédio do Prof. Dr. Luiz Vicente Rizzo.

\subsection{Imortalização dos linfócitos B}

A imortalização dos linfócitos B foi realizada de acordo com o protocolo já estabelecido (Middleton 1991) pela equipe da Profa. Dra. Luiza Guilherme Guglielmi do Laboratório de Imunologia do Instituto do Coração do Hospital das Clínicas da Faculdade de Medicina da Universidade de São Paulo. Foram adicionadas $10^{7}$ células mononucleares do sangue periférico em 2,5ml de meio RPMI-10 (Invitrogen) completo e 2,5ml de sobrenadante com vírus Epstein-Barr (EBV) gentilmente cedido pela Profa. Dra. Luiza Guilherme Guglielmi. Incubou-se por 2 horas em banho-maria a $37^{\circ} \mathrm{C}$. Em seguida, $5 \mathrm{ml}$ de RPMI-10 (Invitrogen) contendo $10 \%$ de soro bovino fetal, $1 \%$ de $\mathrm{L}$-glutamina e $1 \mu \mathrm{g} / \mathrm{ml}$ de ciclosporina $\mathrm{A}$ foram adicionados. $\mathrm{O}$ volume 
final de $10 \mathrm{ml}$ foi transferido para uma garrafa de cultura. Incubou-se a $37^{\circ} \mathrm{C}, 5 \% \mathrm{CO}_{2}$ por três semanas. Após este período, o meio tornou-se ácido e as células formaram grumos macroscópicos. Ao microscópio várias células pareceram grandes, claras e tendendo a formar grumos de tamanhos variados. O repique das células foi feito a cada três dias com meio RPMI ou DMEM Advanced (Invitrogen) com 10\% soro bovino fetal (Invitrogen) 1\% penicilina/estreptomicina (Invitrogen) e 1\% de Lglutamina (Invitrogen).

\subsection{Caracterização fenotípica dos linfócitos B imortalizados}

Dois milhões e meio de células imortalizadas foram centrifugadas a 300xg por 10 minutos e ressuspendidas em $2,5 \mathrm{ml}$ PBS contendo $1 \%$ de soro bovino fetal (Invitrogen) e $0,1 \%$ de azida sódica. Alíquotas de $500 \mu \mathrm{l}\left(5 \times 10^{5}\right.$ células) foram incubadas com anticorpos monoclonais (Kaneko) anti-CD4, anti-CD8 e anti-CD19, conjugados com isotiocianato de fluoresceína (FITC), ficoeritrina (PE) ou CyChrome (PE Cy5) (BD Biosciences) durante 30 minutos a $4^{\circ} \mathrm{C}$ e protegido da luz. Em seguida foram efetuadas duas lavagens em PBS $+1 \%$ de soro bovino fetal $+0,1 \%$ de azida sódica. As células foram ressuspendidas em $500 \mu \mathrm{l}$ dessa mesma solução e submetidas à leitura em citômetro de fluxo (FACS Calibur e FACS Vantage SE - BD Biosciences).

\subsection{Marcação com AnexinaV-FITC e lodeto de Propídio}

Quinhentas mil células foram lavadas com tampão de ligação (10mM Hepes $(\mathrm{pH}=7,4), 150 \mathrm{mM} \mathrm{NaCl}, 5 \mathrm{mM} \mathrm{KCl}, 1 \mathrm{mM} \mathrm{MgCl}_{2}, 1,8 \mathrm{mM} \mathrm{CaCl}_{2}$ ) e em seguida 
ressuspendidas em $100 \mu \mathrm{l}$ do mesmo tampão contendo anexinaV-FITC na concentração 1:500. Incubou-se as amostras por 20 minutos a temperatura ambiente protegidas da luz. Em seguida foi acrescentado $400 \mu$ le tampão de ligação e $40 \mu$ l de solução com iodeto de propídio na concentração de $100 \mu \mathrm{g} / \mathrm{ml}$. As amostras foram imediatamente analisadas em citômetro de fluxo (FACS Calibur BD Biosciences). 


\section{RESULTADOS E DISCUSSÃO}

Nosso grupo identificou anteriormente uma paciente com CVID apresentando expressão alterada do fator de transcrição XBP-1 (Baracho 2006). Esta paciente (paciente P) apresentou menor expressão da proteína spliced em células do sangue periférico na análise por Western Blot (figura 6). Foram analisados por Baracho 26 pacientes com CVID e 26 controles saudáveis. Dada a importância do XBP-1 spliced na ativação da maquinaria secretória de imunoglobulinas por plasmócitos, postulamos que este defeito pode estar relacionado à hipogamaglobulinemia apresentada pela paciente.

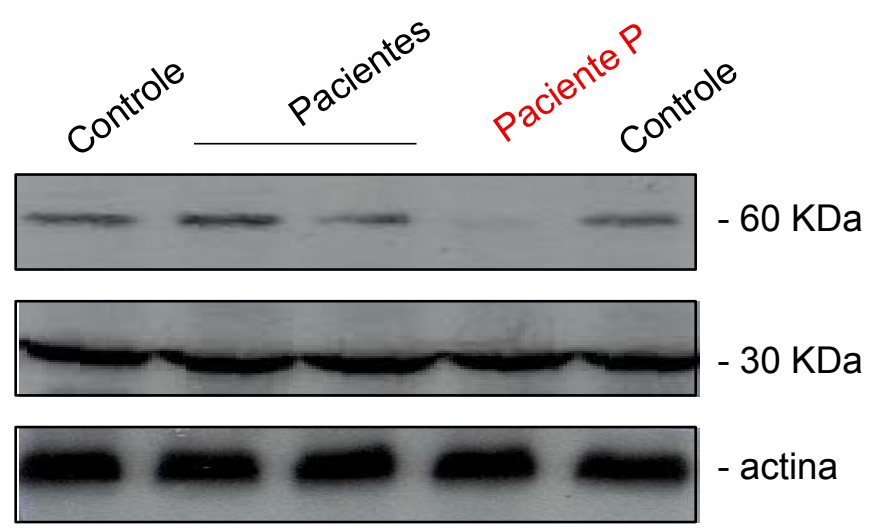

Figura 6: Análise por Western Blot do fator de transcrição XBP-1 em células mononucleares do sangue periférico ex vivo. Na canaleta 4 observamos a paciente $\mathrm{P}$ com expressão diminuída da forma processada do XBP-1 (60 KDa). Os resultados mostrados são representativos de um total de 20 pacientes com CVID e 15 controles saudáveis analisados.

\subsection{Caracterização fenotípica das células mononucleares do sangue periférico da paciente $\mathbf{P}$}

A paciente $P$ foi diagnosticada com CVID aos 16 anos após apresentar pneumonias recidivantes (média de quatro por ano), sinusite crônica e episódios freqüentes de infecção intestinal por mais de 10 anos. Ela não apresentava outras 
manifestações secundárias como doenças autoimunes, neoplasias ou atopia. No momento do diagnóstico, a paciente apresentava $324 \mathrm{mg} / \mathrm{dL}$ de lgG (valor de referência $=952-1538 \mathrm{mg} / \mathrm{dL}$ ), $26 \mathrm{mg} / \mathrm{dL}$ de $\operatorname{lgM}$ (valor de referência $=73-171$ $\mathrm{mg} / \mathrm{dL}$ ) e $7 \mathrm{mg} / \mathrm{dL}$ de $\mathrm{lgA}$ (valor de referência = 69-382 mg/dL).

Como os pacientes podem apresentar defeitos funcionais nas várias subpopulações celulares, buscamos caracterizar de forma mais completa o imunofenótipo apresentado pela paciente P. Realizamos a contagem total e diferencial de leucócitos (tabela 1A) e marcação de moléculas de superfície celular para avaliar as subpopulações de células mononucleares circulantes no sangue periférico. Uma primeira análise destes marcadores foi feita por Errante (2004) e, três anos depois, realizamos uma segunda análise (tabela 1B).

A)

\begin{tabular}{l|c|c}
\hline \hline Populações celulares & Paciente P & Valores de referência* \\
\hline Leucócitos totais & $8,78 \mathrm{mil} / \mathrm{mm}^{3}$ & 5 a $10 \mathrm{mil} / \mathrm{mm}^{3}$ \\
\hline Neutrófilos & $4,5 \mathrm{mi} / \mathrm{mm}^{3}$ & 2 a $7 \mathrm{mil} / \mathrm{mm}^{3}$ \\
\hline Linfócitos & $1,9 \mathrm{mil} / \mathrm{mm}^{3}$ & 0,5 a $3,4 \mathrm{mil} / \mathrm{mm}^{3}$ \\
\hline Monócitos & $0,7 \mathrm{mil} / \mathrm{mm}^{3}$ & 0,1 a $1 \mathrm{mil} / \mathrm{mm}^{3}$ \\
\hline Eosinófilos & $0,1 \mathrm{mi} / \mathrm{mm}^{3}$ & 0 a $0,7 \mathrm{mil} / \mathrm{mm}^{3}$ \\
\hline Basófilos & $0,0 \mathrm{mil} / \mathrm{mm}^{3}$ & 0 a $0,2 \mathrm{mi} / \mathrm{mm}^{3}$ \\
\hline
\end{tabular}

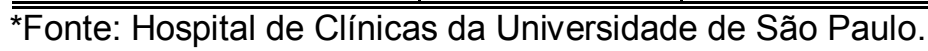

B)

\begin{tabular}{l|c|c|c}
\hline \hline Marcadores & Paciente P 2004 (\%) $^{*}$ & Paciente P 2007 (\%) & Valores de referência (\%) \\
\hline CD3 & 41,7 & 44,3 & 60 a 70 \\
\hline CD3CD4 & 18,2 & 21,65 & 35 a 60 \\
\hline CD3CD8 & 22,6 & 20,4 & 20 a 30 \\
\hline CD3CD25 & 0,45 & 1,04 & 0,4 a 6,0 \\
\hline CD4CD45RA & 8,03 & 5,64 & 24 a 50 \\
\hline CD4CD45RO & 1,1 & 5,98 & 9,5 a 35 \\
\hline CD8CD57 & 14,3 & 5,63 & 0,0 a 11 \\
\hline CD14 & 7 & 18,85 & 2,9 a 13,3 \\
\hline CD16CD56 & 0 & 13,95 & 6,4 a 15 \\
\hline CD19 & 15,8 & 8,05 & 0 a 1,5 \\
\hline CD19CD25 & 2,6 & 2,6 & 0,5 a 3,2 \\
\hline CD19CD27 & 2,2 & 2,43 & \multicolumn{2}{c}{} \\
\hline \hline
\end{tabular}

${ }^{*}$ Análise realizada por Errante 2004.

Tabela 1: Análise das subpopulações celulares da paciente P. A) Números absoluto e relativo das subpopulações de leucócitos.

B) Porcentagem das subpopulações obtida pela marcação de moléculas de superfície das células mononucleares do sangue periférico da paciente $\mathrm{P}$ nos anos de 2004 e 2007. 
Os números absolutos e relativos das subpopulações de leucócitos mantiveram-se dentro dos valores considerados normais nos últimos três anos. No entanto, a paciente $\mathrm{P}$ apresentou valores bastante diferentes para algumas populações de células mononucleares nas duas avaliações. A população de células NK não estava presente na primeira análise e no momento encontra-se dentro dos valores considerados normais enquanto a população de células CD14 ${ }^{+}$(monócitos) teve um aumento de mais de $100 \%$ entre as duas avaliações. Todavia, essas diferenças podem ser apenas um reflexo do estado de ativação do sistema imune frente a um antígeno sem maiores conseqüências para a paciente $P$.

Nas duas avaliações a paciente $\mathrm{P}$ apresentou linfócitos T CD4 ${ }^{+}$abaixo dos valores considerados normais com conseqüente redução das subpopulações de linfócitos T $\mathrm{CD}^{+}$naïve e de memória. Esta alteração no número de células CD4 ${ }^{+}$ gera uma proporção invertida entre linfócitos $\mathrm{T} \mathrm{CD4}^{+}$e $\mathrm{CD}^{+}$. Em 2004, a razão CD4:CD8 $(0,81: 1)$ da paciente $P$ estava fora do valor considerado normal (2:1). Esta alteração foi mantida durante os últimos três anos, como podemos observar na

\section{figura 7 .}

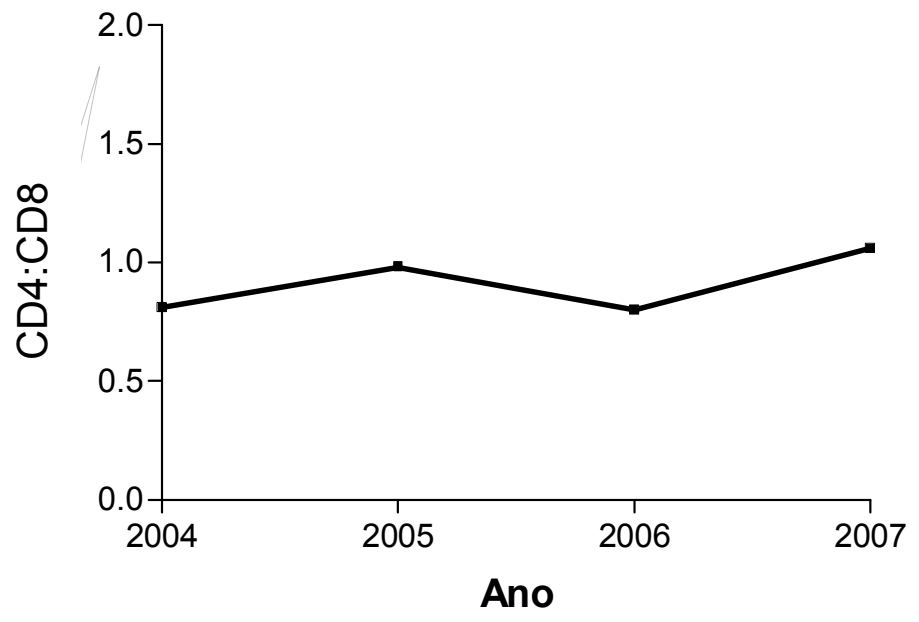

Figura 7: Proporção entre os linfócitos T CD4 e CD8 no sangue periférico da paciente P nos últimos três anos (2004 - 2007). 
A proporção invertida de células CD4:CD8 deve-se apenas ao baixo número de linfócitos $\mathrm{T} \mathrm{CD}^{+}$apresentado pela paciente já que o número de linfócitos T CD8 ${ }^{+}$ encontra-se dentro dos valores normais. Esta alteração parece ser uma constante considerando-se que foram feitas quatro análises com intervalos de um ano e em todas observamos uma razão em torno de um linfócito T CD4 ${ }^{+}$para cada CD8 ${ }^{+}$.

Na ausência de XBP-1, a atividade celular da via UPR é prejudicada e o processamento e a exportação ineficientes de imunoglobulinas resultam no acúmulo de proteínas não dobradas e conseqüentemente na morte celular (Iwakoshi 2003a). Apesar da expressão diminuída da forma spliced do XBP-1 na análise por Western blot, a paciente $\mathrm{P}$ apresenta números normais de linfócitos $\mathrm{B}$ circulando no sangue periférico (Tabela 1).

\subsection{Localização intracelular de cadeias de IgM nos plasmócitos da paciente $P$}

A identificação da deficiência na proteína XBP-1s na paciente $P$ por Baracho (2006) nos levou a crer que a diminuição do fator spliced influencia no fenótipo da doença. Considerando-se que o splicing do XBP-1 é um evento dependente da ativação da via UPR, imaginamos que esta via poderia estar comprometida nesta paciente. Assim, postulamos que os plasmócitos da paciente $\mathrm{P}$ produzem imunoglobulinas, mas têm dificuldades em secretá-las, o que representaria um defeito na via UPR. Para verificar esta hipótese, realizamos a análise por microscopia confocal de linfócitos $B$ da paciente $P$ e de um controle saudável ativadas com $10 \mu \mathrm{g} / \mathrm{ml}$ de LPS por 48 horas e fizemos marcação com anti-lgM e anti-BiP/GRP78 (figura 8). 

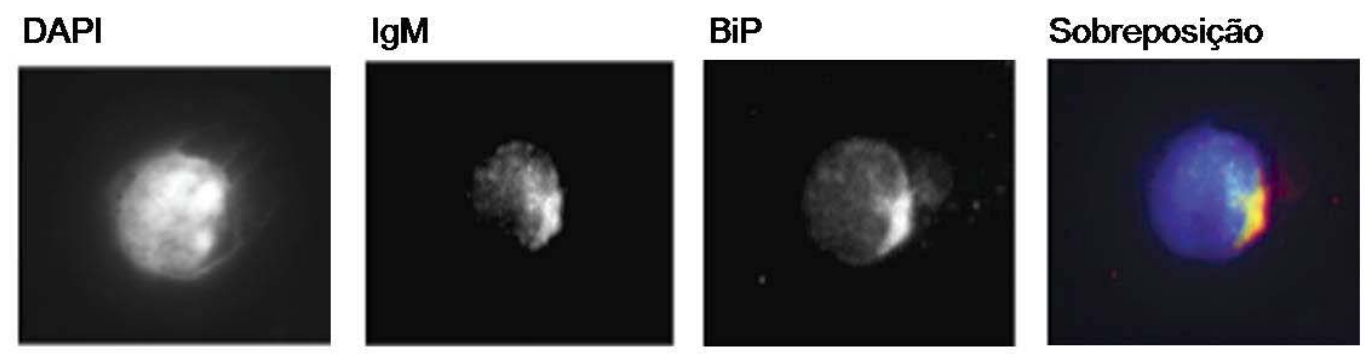

Paciente $\mathbf{P}$
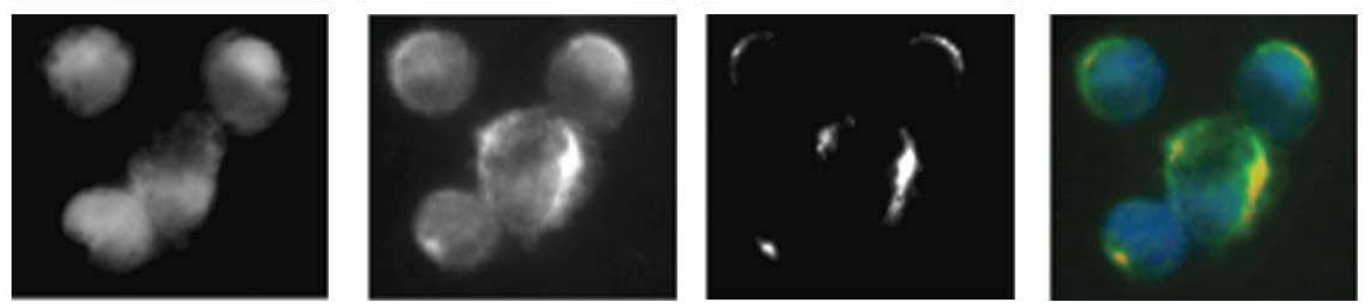

Controle

Figura 8: Expressão de IgM e BiP/GRP78 em células da paciente $\mathrm{P}$ e de um indivíduo controle. As células da paciente $\mathrm{P}$ ou controle foram marcadas com anti-IgM humana (fluorescência verde), antiBiP/GRP78 (fluorescência vermelha) e em seguida foi feita contra-coloração nuclear com DAPI (fluorescência azul). Cada painel apresenta imagens em cinza obtidas para cada marcador, os painéis do lado direito mostram a sobreposição das fluorescências. As microfotografias foram obtidas no aumento 400X. (Dr. Júlio Aliberti)

Na figura 8 observamos uma co-localização do RE com as cadeias de IgM nas células da paciente $P$, mostrando que ocorre a produção destas proteínas mas que elas não são exportadas deste compartimento. As células da paciente $P$ não apresentaram IgM na superfície celular, enquanto observamos claramente a presença de IgM na superfície das células do controle. Assim, supomos que as células desta paciente não conseguem ativar a via UPR corretamente e a resolução de estresse não ocorre de forma satisfatória, resultando no acúmulo de imunoglobulinas desdobradas no interior do RE.

\subsection{Análise da expressão do RNAm para XBP-1 nos pacientes com CVID}

Para verificar a expressão do RNAm para XBP-1, desenhamos uma reação de RT-PCR utilizando três oligonucleotídeos combinados de duas maneiras 
diferentes. A reação utilizando os oligonucleotídeos sense e total antisense resulta em dois produtos, um de 594 pb (produto unspliced) e outro 578 pb (produto spliced), que são indistingüíveis na separação em gel de agarose por causa do tamanho semelhante. Uma segunda reação utilizando os oligonucleotídeos sense e unspliced antisense gera um produto de $282 \mathrm{pb}$ amplificado somente a partir dos RNAm não processados e por isso, possuem a seqüência de 26 nucleotídeos onde o oligonucleotídeo unspliced se anela. $\mathrm{Na}$ figura 9A estão representados resultados típicos para a expressão das duas formas de RNAm. Nesta figura estão representados um indivíduo saudável (canaleta 1) e 12 pacientes com CVID (canaletas 2-13). Diferentes proporções de XBP-1 não processado (produto de 282 $\mathrm{pb}$ ) foram encontradas entre os pacientes. A paciente $\mathrm{P}$ (canaleta 12) apresenta a expressão total de RNAm para XBP-1 quase que equivalente à expressão da forma unspliced, sugerindo que a paciente apresenta falhas no processamento do RNAm para XBP-1.

Na figura 9B podemos observar resultados típicos da análise densitométrica das bandas obtidas na amplificação do RNAm total e unspliced para XBP-1 na figura 9A. A figura mostra um controle saudável (barra 1) e 12 pacientes (numerados de 1 a 11 mais a paciente $P$ ). A paciente $P$ apresentou $87 \%$ do seu RNAm para XBP-1 na forma não processada, contra aproximadamente $38 \%$ do controle saudável e saudável e 33 - 64\% entre os demais pacientes de CVID. 
A)

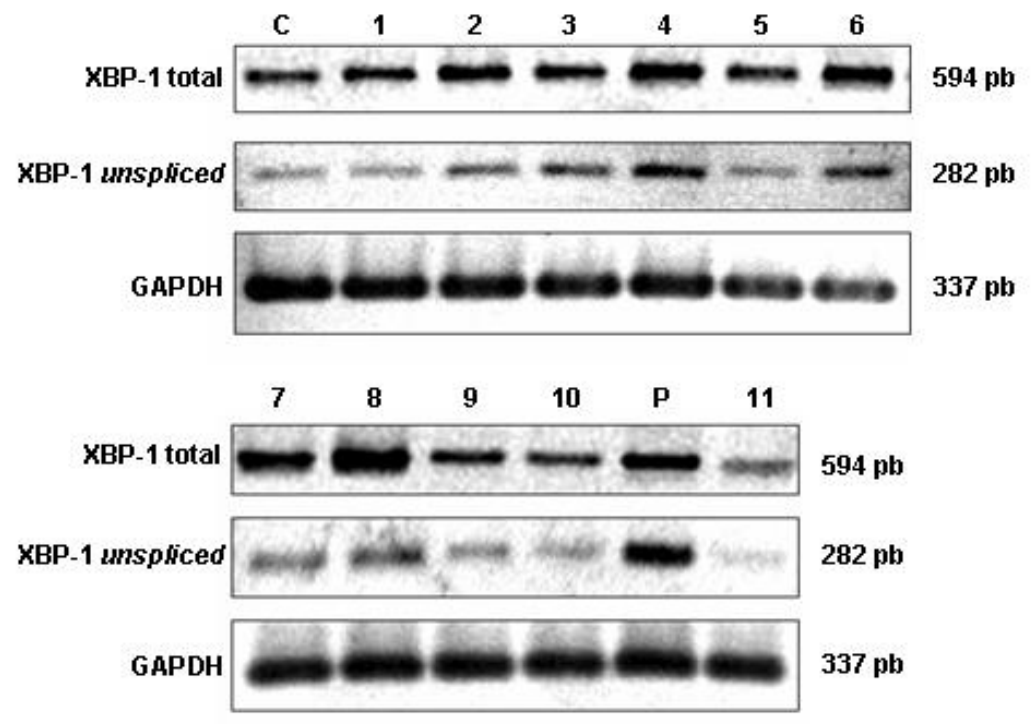

B)

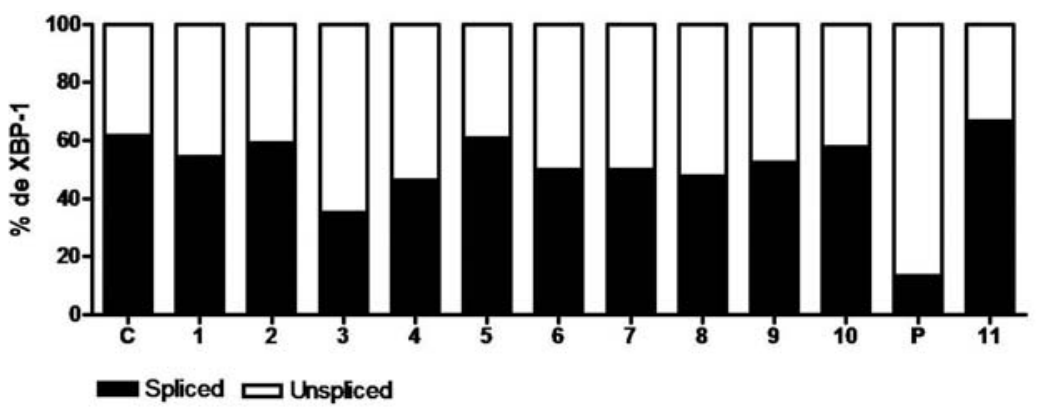

Figura 9: Expressão das formas total e unspliced do RNAm para XBP-1. A) O RNAm de XBP-1 foi analisado utilizando-se duas combinações de oligonucleotídeos distintas. A banda de $594 \mathrm{pb}$ corresponde ao RNAm total para XBP-1. A banda de 282 pb foi gerada com uma combinação na qual um dos oligonucleotídeos anela na região de 26 nucleotídeos que é eliminada durante o processamento, correspondendo à forma unspliced do RNAm. A canaleta 1 representa um indivíduo controle. As demais representam pacientes. B) Análise densitométrica dos produtos de RT-PCR para XBP-1 unspliced e spliced. A porcentagem de XBP-1 spliced foi calculada assumindo-se que a soma da formas spliced e unspliced resulta na expressão total do RNAm para XBP-1.

Verificamos na figura 9 que a paciente $P$ apresenta uma pequena produção de RNAm spliced. A ausência do produto protéico apesar da presença do RNAm spliced, ocorre porque a proteína XBP-1 apresenta meia-vida curta (aproximadamente 1 hora). Assim, quando a produção de RNAm de XBP-1 é baixa, 
a visualização da proteína por Western blot é dificultada (Yoshida 2001). A presença deste RNAm demonstra que a célula da paciente $\mathrm{P}$ consegue processar uma parte dos transcritos para XBP-1.

\subsection{Seqüenciamento do RNAm do XBP-1 da paciente $P$}

Em seguida foi verificado se mutações no RNAm do XBP-1 da paciente $P$ poderiam estar impedindo o processamento pela IRE-1 $\alpha$, o que explicaria os níveis mais altos de mensagem não processada encontrados na paciente. Plasmídios, contendo teoricamente tanto a mensagem processada quanto a não processada, foram seqüenciados. Todas as 18 amostras seqüenciadas continham a versão não processada, mas nenhuma apresentou mutações 600 pb acima e/ou abaixo do íntron de $26 \mathrm{pb}$ (figuras 10A e B).

Desta forma, excluímos a possibilidade de que o próprio RNAm de XBP-1 estivesse dificultando o seu processamento pela presença de mutações que impedissem o reconhecimento e splicing pela IRE-1 $1 \alpha$. 
A)

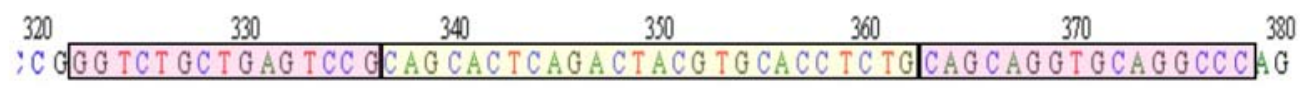

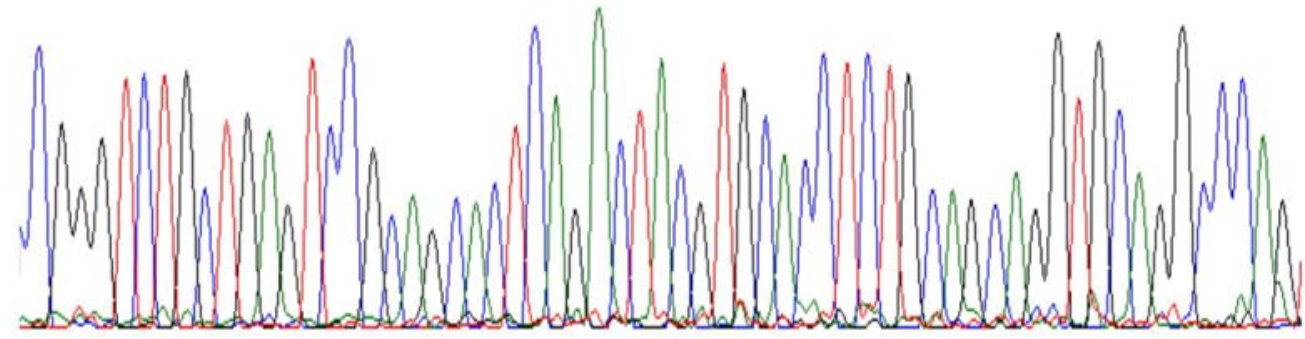

Sítio de ligação da IRE-1 $\alpha$

26 nucleotídeos excisionados pela IRE-1 $\alpha$

B)

\begin{tabular}{|c|c|c|c|}
\hline Query & 1 & AACAGAGTAGCAGCTCAGACTGCCAGAGATCGAAAGAAGGCTCGAATGAGTGAGCTGGAA & 60 \\
\hline Sbjet & 257 & AACAGAGTAGCAGCTCAGACTGCCAGAGATCGAAAGAAGGCTCGAATGAGTGAGCTGGAA & 316 \\
\hline Query & 61 & CAGCAAGTGGTAGATTTAGAAGAAGAGAACCAAAAACTTTTGCTAGAAAATCAGCTTTTA & 120 \\
\hline Sbjet & 317 & CAGCAAGTGGTAGATTTAGAAGAAGAGAACCAAAAACTTTTGCTAGAAAATCAGCTTTTA & \\
\hline Query & 121 & CGAGAGAAAACTCATGGCCTTGTAGTTGAGAACCAGGAGTTAAGACAGCGCTTGGGGATG & \\
\hline Sbjet & 377 & CGAGAGAAAACTCATGGCCTTGTAGTTGAGAACCAGGAGTTAAGACAGCGCTTGGGGATG & \\
\hline uery & 181 & GATGCCCTGGTTGCTGAAGAGGAGGCGGAAGCCAAGGGGAATGAAGTGAGGCCAGTGGCC & \\
\hline Sbjet & 437 & GATGCCCTGGTTGCTGAAGAGGAGGCGGAAGCCAAGGGGAATGAAGTGAGGCCAGTGGCC & \\
\hline Query & 241 & GGGTCTGCTGAGTCCGCAGCACTCAGACTACGTGCACCTCTGCAGCAGGTGCAGGCCCAG & \\
\hline Sbjct & 497 & GGGTCTGCTGAGTCCGCAGCACTCAGACTACGTGCACCTCTGCAGCAGGTGCAGGCCCAG & 556 \\
\hline Query & 301 & TTGTCACCCCTCCAGAACATCTCCCCATGGATTCTGGCGGTATTGACTCTTCAGATTCAG & \\
\hline Sb jet & 557 & TTGTCACCCCTCCAGAACATCTCCCCATGGATTCTGGCGGTATTGACTCTTCAGATTCAG & \\
\hline Query & 361 & GGCATTCTGGACAACTTGGACCCAGTCATGTTCTTCAAATGCC & 420 \\
\hline Sbjet & 617 & AGTCTGATATCCTGTTGGGCATTCTGGACAACTTGGACCCAGTCATGTTCTTCAAATGCC & 576 \\
\hline uery & 421 & GGTCTACCC & \\
\hline 0$] \mathrm{ct}$ & 677 & CCAGA & \\
\hline
\end{tabular}

Figura 10: Seqüenciamento do RNAm xbp1 da paciente P. A) No cromatograma observamos em rosa os sítios de ligação da IRE-1 sem mutações e observamos a presença do íntron (em amarelo) sendo este um cromatograma típico das amostras seqüenciadas. B) Seqüência obtida pela análise da região próxima ao sítio de splicing alternativo do XBP-1 da paciente $\mathrm{P}$. Em destaque verde o íntron de 26 nucleotídeos excisionado pela IRE-1 $\alpha$. As seqüências de nucleotídeos da fita positiva de DNA da paciente P foram alinhadas com a seqüência depositada no GenBank (gi:14110394). 


\subsection{Ensaios de estresse celular para ativação da via UPR em uma população celular enriquecida com linfócitos B}

A CVID pode ser uma imunodeficiência combinada em que parte da síntese prejudicada de imunoglobulinas deve-se à interação ineficiente entre os linfócitos T e B. Os linfócitos B recebem um estímulo para se diferenciarem in vivo (p. ex., via receptor de antígeno (BCR), CD40, e receptores de citocinas) e o retículo endoplasmático expande para acomodar as cadeias nascentes de imunoglobulinas. Esse estímulo rapidamente aumenta a transcrição do RNAm de XBP-1 e a presença das cadeias de imunoglobulinas não dobradas estimulam o splicing mediado pela IRE-1 $\alpha$ (Iwakoshi 2003a). Desta forma, defeitos na sinalização/interação entre linfócitos T e B podem não induzir uma diferenciação adequada dos linfócitos B e conseqüente ativação da via UPR.

Assim, cogitamos a possibilidade da via UPR não ser ativada corretamente em decorrência de uma estimulação ineficaz do linfócito $B$ da paciente $P$ por causa do número reduzido de linfócitos $\mathrm{T} \mathrm{CD4}^{+}$. A ausência do estímulo prejudicaria a diferenciação terminal em plasmócitos e por isso a via UPR não seria desencadeada apropriadamente, resultando em baixa taxa de splicing do RNAm XBP-1. Seguindo este raciocínio, quando induzíssemos a via UPR diretamente com uma substância estressora de RE, as células da paciente $P$ apresentariam um perfil de ativação semelhante ao controle.

Desta forma, realizamos ensaios de estresse celular. Estes ensaios consistem em tratar uma população celular enriquecida com linfócitos $B$ da paciente $P$ e de um controle com uma substância que cause o estresse do RE e conseqüente ativação da via UPR de maneira BCR-independente. Esta população enriquecida foi obtida 


\section{A desregulação da via UPR associada à Imunodeficiência Comum Variável \\ Juliana Sayuri Kuribayashi}

por seleção negativa de linfócitos B em coluna magnética (MACS Beads) e os linfócitos B representaram aproximadamente $70 \%$ da população celular. A substância estressora escolhida foi a brefeldina $A$, um metabólito fúngico que impede a saída de proteínas recém-sintetizadas do RE. Além disso, a brefeldina A provoca uma rápida ruptura do complexo de Golgi e do transporte retrógado desta organela para o RE (Miller 1992).

Nos ensaios de estresse celular, as células sem tratamento tiveram a expressão relativa considerada como 1 e os valores atribuídos à expressão gênica após os tratamentos foram calculados em relação ao estado basal (sem tratamento).

Na figura 11 observamos a expressão de XBP-1 spliced nas células em estado basal e tratadas com brefeldina A por 8 ou 12 horas. Após 8 horas de tratamento, as células da paciente $\mathrm{P}$ e do controle expressaram, respectivamente, 1,54 e 2,09 vezes mais XBP-1 spliced em comparação ao estado basal. Doze horas após a adição de brefeldina $A$, as células da paciente $P$ tiveram praticamente a mesma expressão de XBP-1 spliced (1,53 vezes maior em relação ao estado basal) enquanto as células do controle apresentaram uma queda na expressão deste RNAm (1,34 vezes maior quando comparadas ao estado basal).

Na figura 12 observamos a expressão relativa de IRE-1 $\alpha$ na população celular enriquecida com linfócitos $\mathrm{B}$ da paciente $\mathrm{P}$ e controle no estado basal (células ex vivo) e após 8 ou 12 horas de tratamento com brefeldina A. As células da paciente $\mathrm{P}$ e do controle expressaram, respectivamente, 1,09 e 1,98 vezes mais IRE- $1 \alpha$ após 8 horas de tratamento em comparação ao estado basal. Após 12 horas, a expressão de IRE-1 $\alpha$ foi 3,41 vezes maior em relação ao estado basal nas células da paciente $P$ enquanto as células do controle apresentaram uma expressão apenas 1,55 vezes maior quando comparadas ao estado basal. 


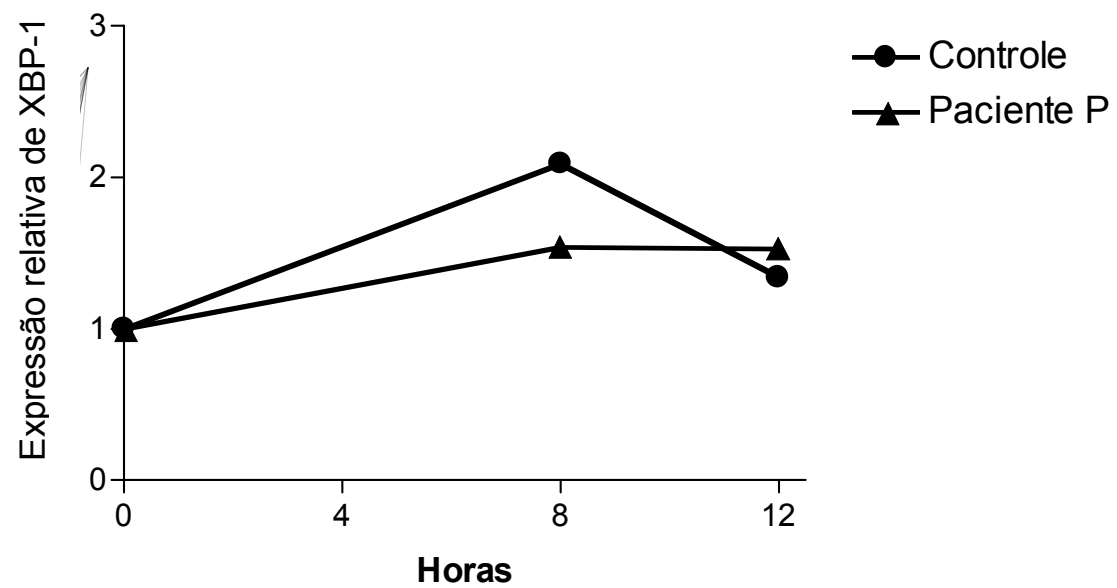

Figura 11: Expressão relativa de XBP-1 spliced em uma população celular enriquecida com linfócitos $B$ da paciente $\mathrm{P}$ e de um controle no estado basal (células ex vivo) e após tratamento com brefeldina A por 8 ou 12 horas.

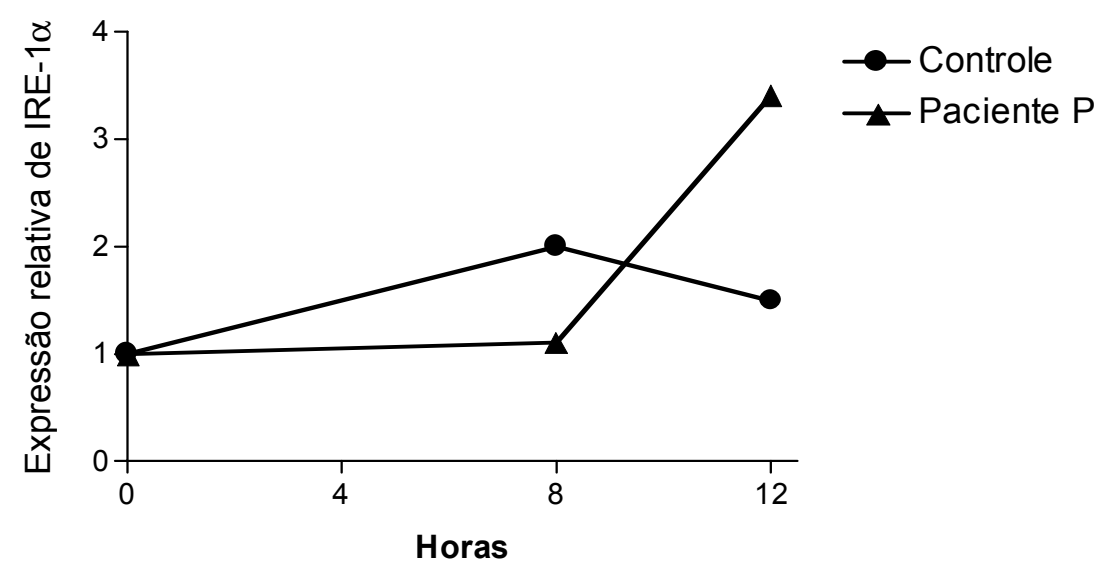

Figura 12: Expressão relativa de IRE-1 $\alpha$ em uma população celular enriquecida com linfócitos $B$ da paciente $\mathrm{P}$ e de um controle no estado basal (células ex vivo) e após tratamento com brefeldina A por 8 ou 12 horas.

Na figura 13 observamos a expressão de BiP nas células no estado basal e tratadas com brefeldina A por 8 ou 12 horas. Com 8 horas de tratamento, as células da paciente $\mathrm{P}$ e do controle expressaram, respectivamente, 1,8 e 5,2 vezes mais BiP em comparação ao estado basal. Após 12 horas, as células da paciente $\mathrm{P}$ apresentaram uma expressão de BiP 2,5 vezes maior em relação ao estado basal 
enquanto a expressão nas células do controle foi 4 vezes maior quando comparadas ao estado basal.

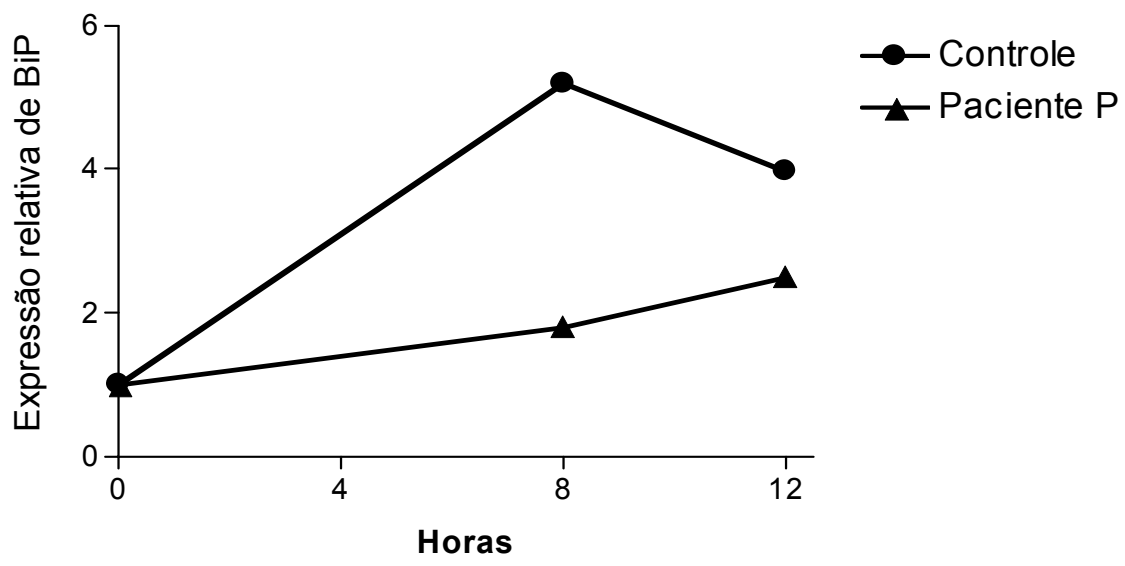

Figura 13: Expressão relativa de $\mathrm{BiP}$ em uma população celular enriquecida com linfócitos $B$ da paciente $\mathrm{P}$ e de um controle no estado basal (células ex vivo) e após tratamento com brefeldina A por 8 ou 12 horas.

Nas figuras 11, 12 e 13, verificamos que a população celular enriquecida com linfócitos $B$ da paciente $P$ apresenta uma resposta mais lenta ao estresse causado pela brefeldina A em relação ao controle. Após 8 horas de tratamento, as células do controle parecem atingir o máximo de transcrição dos genes envolvidos na resolução da via UPR enquanto as células da paciente $P$ ainda estão iniciando a resposta ao estímulo. A análise da expressão gênica após 12 horas de tratamento com brefeldina A reforça esta idéia: as células da paciente $P$ ainda estão aumentando a expressão gênica enquanto as células do controle apresentam uma diminuição na expressão destes genes. Estes resultados indicam que as células do controle foram submetidas a uma situação de estresse, ativaram a via UPR, transcreveram os genes envolvidos na resolução do estresse e estes transcritos foram traduzidos em proteínas capazes de resgatar a homeostasia celular. Assim, nas células do controle, em 12 horas já observamos um declínio no nível de ativação da via UPR. Neste mesmo período, as células da paciente $P$ ainda não conseguiram 
restabelecer o equilíbrio e continuam transcrevendo os genes envolvidos na resolução do estresse.

Os estudos realizados por Baracho também confirmam este resultado. $\mathrm{O}$ tratamento de PBMCs com tapsigargina induziu aumento na expressão de IRE-1 $\alpha$ em relação às células não estimuladas, sendo que na paciente $P$ o efeito foi modestamente inferior ao observado no controle. Quanto à expressão de XBP-1, a indução de estresse com tapsigargina não foi capaz de alterar significativamente as quantidades de produtos de RT-PCR para XBP-1 unspliced. Contudo, a expressão de XBP-1 spliced aumentou cerca de $10 \%$ nas células da paciente $\mathrm{P}$ e aproximadamente $30 \%$ nas células do controle (Baracho 2006).

O aumento mais acentuado na expressão gênica de IRE-1 $\alpha$ e XBP-1s observado nos nossos experimentos em relação àqueles realizados por Baracho provavelmente ocorre porque utilizamos uma população enriquecida com linfócitos B enquanto Baracho utilizou células mononucleares de sangue periférico em que o número de linfócitos B não ultrapassa os $15 \%$. Também devemos considerar o fato que nossas análises foram feitas por PCR em tempo real, uma técnica mais sensível que o PCR convencional utilizado por Baracho.

Esta lentidão na resolução da via UPR observada na paciente $P$ provavelmente compromete o controle de qualidade do RE bem como a síntese e exportação de imunoglobulinas e mantêm as células em um estado pré-ativado com a via UPR sendo desencadeada constantemente. 


\subsection{Apoptose desencadeada pela ativação da via UPR por brefeldina A nas células B ex vivo}

Realizamos marcação com anexina $V$ para verificar se a ativação crônica da via UPR induz apoptose aumentada dos linfócitos $B$ da paciente $P$. As células ex vivo da paciente $\mathrm{P}$ e de três controles saudáveis foram incubadas com brefeldina $\mathrm{A}$ por 24 ou 48 horas e em seguida foram analisadas no citômetro de fluxo (FACS Calibur) para a marcação por anexina V.

Na figura 14 observamos que as células do controle e da paciente $P$ apresentaram taxas semelhantes de apoptose após 24 (figura 14A) ou 48 horas (figura 14B) de incubação com brefeldina A.

A porcentagem de células apóptoticas da paciente $P$ após 24 horas foi maior que os valores observados nas células dos controles e após 48 horas mostrou-se menor.

Semelhantemente ao observado por Lee e colaboradores (2003a), a indução de estresse do RE induziu apoptose dos linfócitos B. Uma possibilidade é que a morte celular observada é desencadeada por causa da ativação crônica da via UPR. Interessantemente, as células da paciente $P$, que apresentam uma resolução mais lenta da via UPR, apresentaram taxas de apoptose semelhantes àquelas observadas nas células de indivíduos saudáveis. No entanto, não podemos afirmar que a cinética mais lenta na indução dos genes alvos da via UPR observada nos linfócitos $B$ da paciente $P$ não induz uma morte celular aumentada destas células. Infelizmente não foi verificado o número de células vivas e mortas para analisar se o número absoluto de células vivas diminuiu após as 48 horas de incubação com brefeldina. 
A)

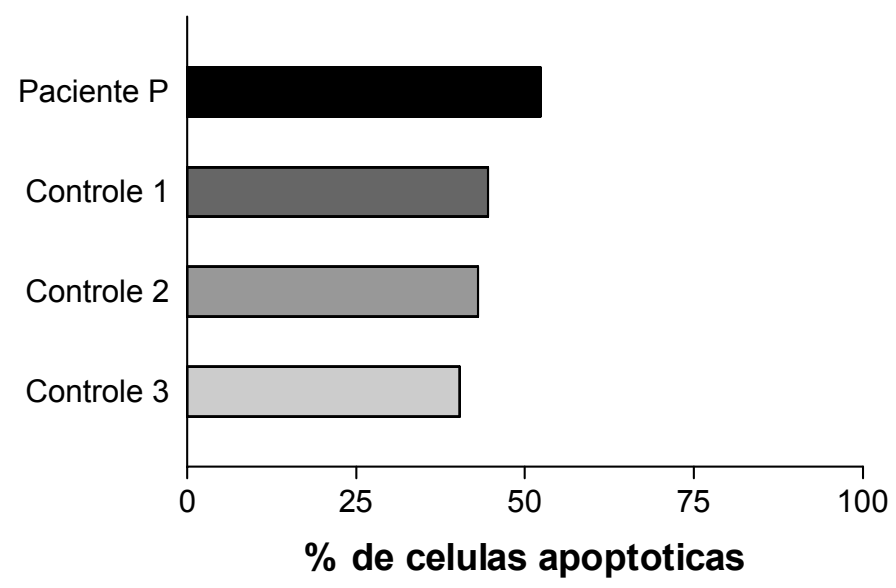

B)

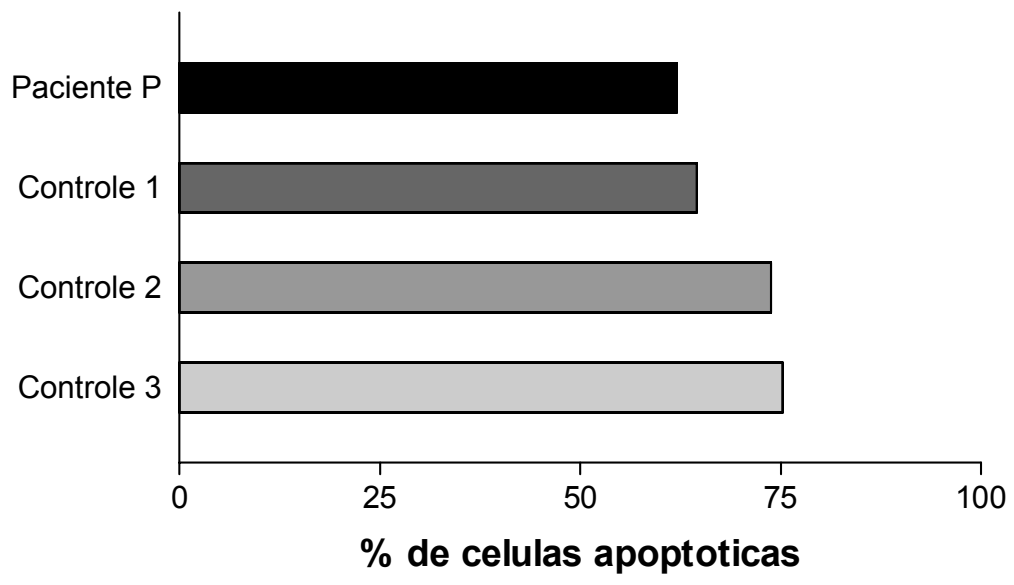

Figura 14: Apoptose (marcação para anexina $V$ ) induzida por brefeldina $A$ em linfócitos $B$ da paciente $P$ e de três controles saudáveis. A) Linfócitos $B$ tratados com brefeldina A por 24 horas. B) Linfócitos B tratados com brefeldina A por 48 horas.

\subsection{Diminuição do estresse celular de células ex vivo com a utilização de chaperona química}

Considerando que as chaperonas químicas são substâncias de baixo peso molecular capazes de reverter a retenção intracelular de proteínas mal-dobradas, realizamos ensaios com a chaperona química dimeltilsulfóxido (DMSO). As chaperonas estabilizam a conformação de intermediários de proteínas mutantes 
favorecendo o dobramento correto, exportação do RE e subseqüente tráfego para o compartimento celular adequado (Bernier 2004).

Assim, realizamos os mesmos ensaios de estresse celular utilizando $1 \mu \mathrm{lde}$ DMSO para cada $1 \mathrm{ml}$ de meio de cultura (figura 15). Verificamos que o tratamento com DMSO por 8 horas correlacionou-se com uma diminuição na expressão dos RNAm para XBP-1s, IRE-1 $\alpha$ e BiP nas células da paciente P. No entanto, a expressão de IRE-1 $\alpha$ e BiP permaneceu inalterada nas células do controle e o tratamento com DMSO foi correlacionado com menor expressão de XBP-1s.

A)

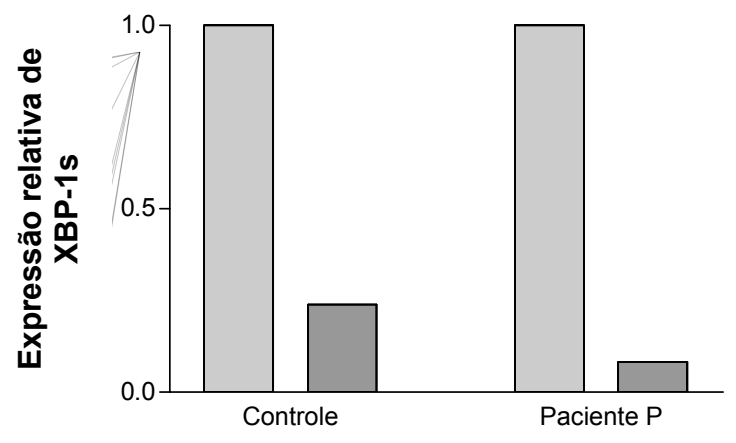

C)
B)

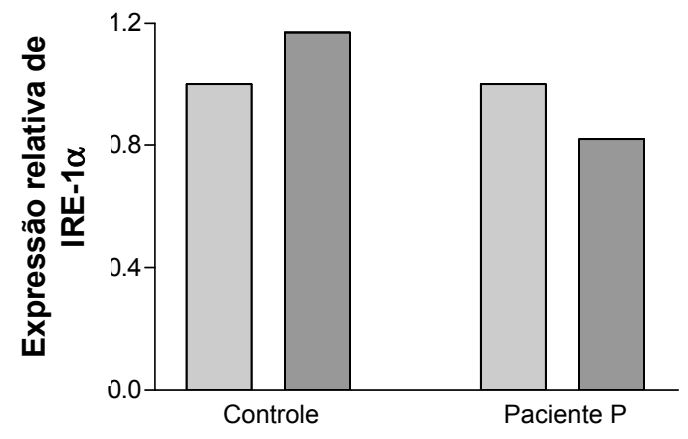

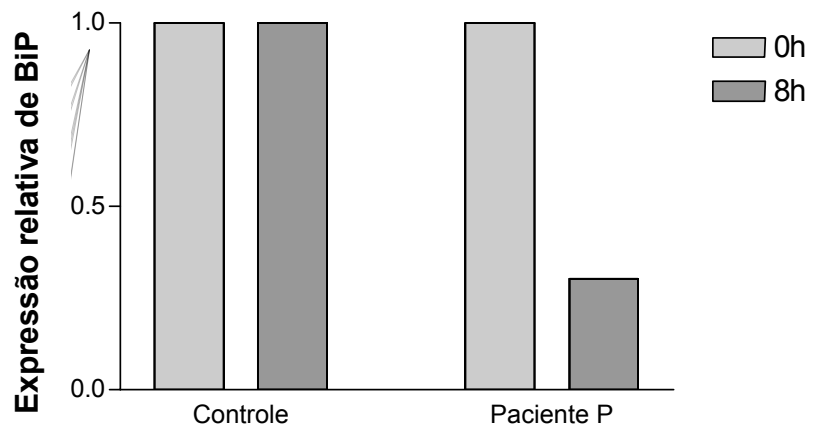

Figura 15: Expressão relativa dos RNAm para XBP-1 spliced (A), IRE-1 $\alpha(B)$ e BiP (C) em uma população celular enriquecida com linfócitos $B$ da paciente $\mathrm{P}$ e de um controle no estado basal (células ex vivo) ou após tratamento com DMSO por 8 horas.

Um estudo demonstrou que as chaperonas químicas 4-phenyl butyric acid (PBA) e taurine-conjugated derivative (TUDCA) são capazes de proteger células de 
hepatoma de rato do estresse do RE experimental. Estas substâncias reduziram o splicing do XBP-1 e a fosforilação de PERK e elF2 $\alpha$ em situações de estresse do RE induzidas por tunicamicina (Ozcan 2006).

Os nossos resultados estão em concordância com estes obtidos por Ozcan (2006). As células ex vivo da paciente P e do controle apresentaram uma diminuição na expressão de XBP-1s em relação ao estado basal após o tratamento com DMSO. A diminuição mais acentuada na paciente $P$, tanto de XBP-1s quanto de BiP, pode ser explicada pela observação de que células $\mathrm{XBP}-1^{-/-}$são mais sensíveis ao estresse do RE por causa da capacidade de dobramento do RE diminuída (Ozcan 2004; Shaffer 2004). Assim, postulamos que as células da paciente $P$, que apresentam um desbalanço na expressão das formas spliced e unspliced do XBP-1, são mais sensíveis ao estresse do RE em relação às células do controle. Uma vez mais sensíveis, estas células apresentam um nível de ativação da via UPR mais elevado do que o controle no estado basal e, portanto, também são mais sensíveis à ação de chaperonas químicas na modulação do estresse do RE.

Desta forma, imaginamos que o DMSO é capaz de aliviar o estresse desencadeado pelo acúmulo de cadeias de imunoglobulinas nas células da paciente P. Esta nossa hipótese baseia-se no relato de algumas doenças humanas (como por exemplo, a fibrose cística) caracterizadas por mutações pontuais ou deleções que geram produtos protéicos incapazes de atingir o estado de dobramento correto e estável, mas não necessariamente interferem na função destas proteínas (Welch 1996; Barral 2004). Estudos com a fibrose cística, doença causada por mutações no gene que codifica a proteína reguladora de condutância iônica transmembrana (CFTR), mostraram que os sistemas de controle de qualidade protéica podem ser manipulados com a utilização de chaperonas químicas (Welch 1996). A deleção do 
resíduo fenilalanina na posição 508 da proteína CFTR ( $\Delta$ F508 CFTR) resulta em falha no tráfego da proteína para a membrana plasmática e impede o transporte de cloreto em resposta ao aumento de cAMP intracelular. O tratamento de células $\Delta$ F508 CFTR com glicerol ou DMSO aumentou a maturação da proteína mutante e recuperou a condutância de cloreto ativada por cAMP (Brown 1996).

Outro grupo de pesquisadores utilizou chaperonas químicas para aliviar o estresse do RE desencadeado em camundongos obesos. Foi mostrado que camundongos deficientes para XBP-1 desenvolvem resistência à insulina e diabetes do tipo 2 e que a obesidade induz estresse do RE desencadeando atividade JNK via IRE-1 $\alpha$ e inibição da sinalização via receptor de insulina (Ozcan 2004). Neste estudo as chaperonas químicas foram capazes de modular a atividade do RE e aumentar a capacidade de dobramento melhorando a ação sistêmica da insulina (Ozcan 2006).

Considerando-se estes trabalhos, postulamos que o DMSO diminuiu o estresse do RE desencadeado pelo acúmulo de cadeias de imunoglobulinas não dobradas células da paciente $P$.

\subsection{Ativação de células ex vivo com LPS}

Considerando que o LPS induz a secreção de imunoglobulinas em linfócitos B in vitro e que a secreção destas depende da ativação da via UPR, tratamos as populações de células mononucleares do sangue periférico enriquecidas em linfócitos B com $10 \mu \mathrm{g} / \mathrm{ml}$ de LPS por 48 horas. Após o tratamento com LPS, verificamos por PCR em tempo real a expressão relativa dos RNAm para XBP-1 spliced (figura 16A), IRE-1 $\alpha$ (figura 16B) e BiP (figura 16C). 
Em 48 horas, os RNAm para XBP-1s, IRE-1 $\alpha$ e BiP apresentaram expressão diminuída em relação ao estado basal tanto nas células da paciente $P$ quanto no controle.

A figura 16A mostra as células sem tratamento com expressão relativa considerada como 1. Após o tratamento com LPS os valores de expressão XBP-1s no controle e na paciente $P$ foram 0,1 e 0,08 respectivamente. Na figura 16B observamos a expressão do RNAm para IRE-1 $1 \alpha$ e verificamos que após o tratamento com LPS os valores de expressão IRE-1 $\alpha$ no controle e na paciente $P$ foram 0,56 e 0,008 respectivamente. A figura 16C mostra a expressão do RNAm para BiP. Após o tratamento com LPS os valores de expressão BiP no controle e na paciente $\mathrm{P}$ foram 0,44 e 0,007 respectivamente.

O sobrenadante das células tratadas com LPS por 48 horas foi utilizado para dosagem de imunoglobulinas. Na figura 17 observamos a produção de $\lg$ M e $\lg G$ pelas células do controle e da paciente P. Notamos que as células da paciente $P$ produziram menos imunoglobulinas em comparação ao controle, o que condiz com o diagnóstico de hipogamaglobulinemia apresentado pela mesma e está de acordo com nossa hipótese de que esta paciente apresenta defeitos na via UPR e menor splicing do XBP-1 relacionados ao acúmulo de imunoglobulinas não dobradas no RE. 
A)

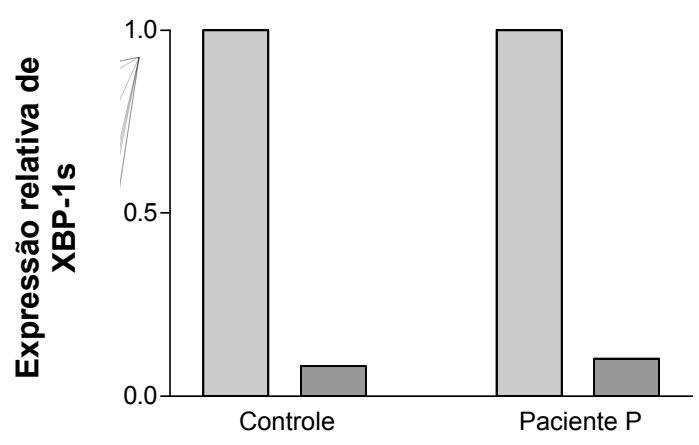

B)

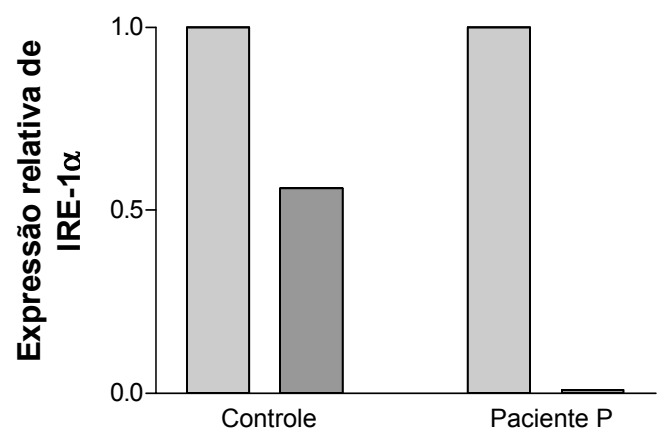

C)

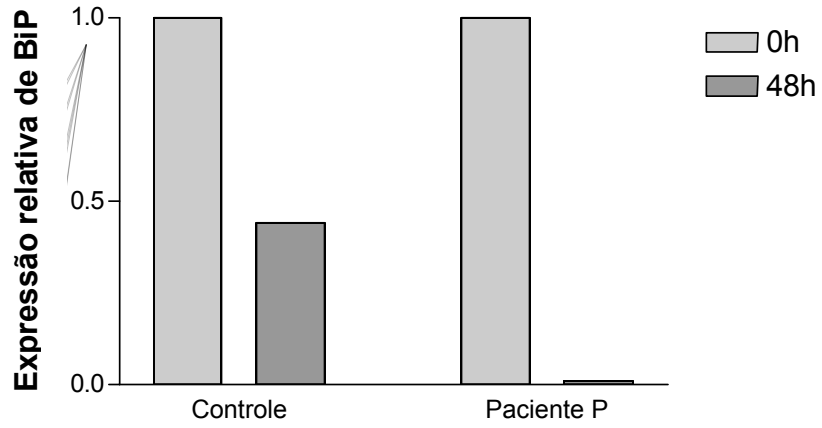

Figura 16: Expressão relativa dos RNAm para XBP-1 spliced (A), IRE-1 $\alpha$ (B) e BiP (C) em uma população celular enriquecida com linfócitos $B$ da paciente $P$ e de um controle após tratamento com LPS por 48 horas.

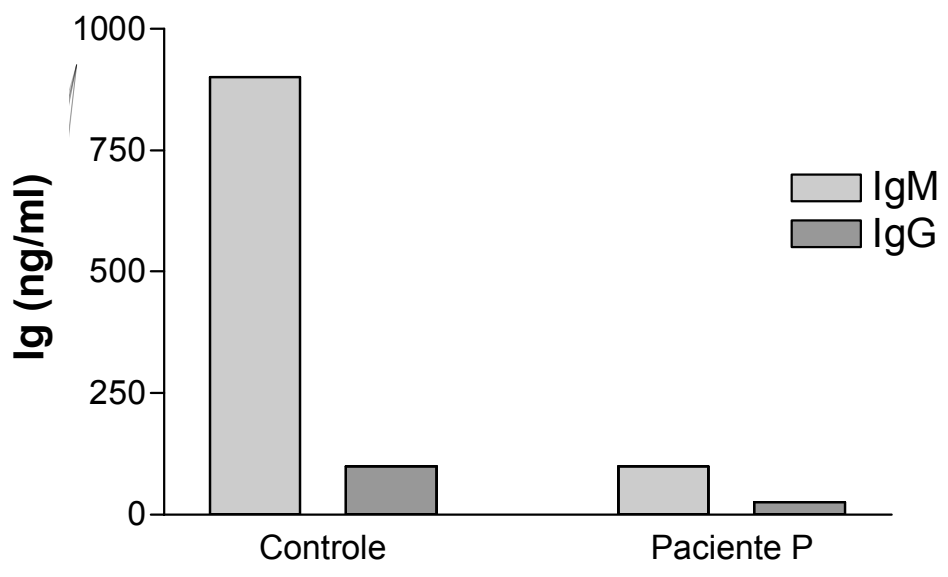

Figura 17: Produção de imunoglobulinas em uma população celular enriquecida com linfócitos $B$ da paciente $\mathrm{P}$ e de um controle no estado basal (células ex vivo) ou após tratamento com LPS por 48 horas. 


\subsection{Caracterização dos linfócitos $B$ imortalizados com vírus Epstein-Barr}

As células ex vivo utilizadas nos ensaios de estresse celular constituíam uma população heterogênea, apesar de ser enriquecida com linfócitos B. Além disso, as células do controle e da paciente $\mathrm{P}$ estavam sujeitas à condições diferentes antes do experimento: citocinas presentes na corrente sangüínea e ativação e interação com outras células do sistema imune. Para contornarmos estes problemas, realizamos os experimentos de estresse celular com linfócitos B imortalizados com o vírus EpsteinBarr.

Três semanas após a imortalização, verificamos que a cultura apresentava grumos celulares característicos de linfócitos B imortalizados por EBV. Então, verificamos por citometria de fluxo que havia apenas linfócitos B na cultura por meio da marcação das moléculas de superfície CD4, CD8 e CD19 (dado não mostrado).

As células imortalizadas foram tratadas com LPS por 48 horas e o sobrenadante foi coletado para dosagem de imunoglobulinas. Na figura 18, verificamos que estas células continuaram funcionais após a imortalização. Os linfócitos $B$ da paciente $P$ continuaram secretando baixas quantidades de imunoglobulinas quando estimuladas. 


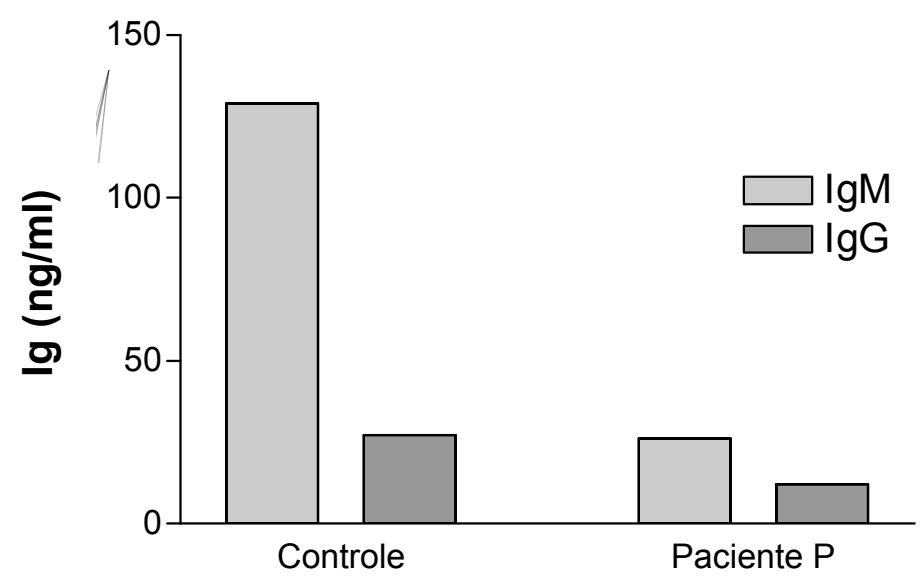

Figura 18: Produção de imunoglobulinas pelos linfócitos B imortalizados com vírus Epstein-Barr da paciente $\mathrm{P}$ e de um controle no estado basal ou após tratamento com LPS por 48 horas.

Os pacientes com CVID apresentam linfócitos B circulantes, mas o número absoluto freqüentemente está reduzido como reflexo de um grau variável de linfopenia (Guo 1995). As células B destes pacientes em geral proliferam normalmente in vitro, mas não se diferenciam em células produtoras de imunoglobulinas (Guo 1995; Cunningham-Rundles 1999). Guo e colaboradores (1995) imortalizaram linfócitos B de pacientes com CVID e indivíduos saudáveis e verificaram que as células dos pacientes sofriam apoptose espontânea ou induzida em taxas maiores do que as células provenientes de indivíduos saudáveis. Em concordância com estes resultados, nós também verificamos que as células imortalizadas com vírus Epstein-Barr da paciente $\mathrm{P}$ apresentaram proliferação diminuída quando comparadas às células do controle (figura 19). No entanto, não sabemos se essa proliferação reduzida é devido a uma divisão celular mais lenta ou um maior índice de morte. 


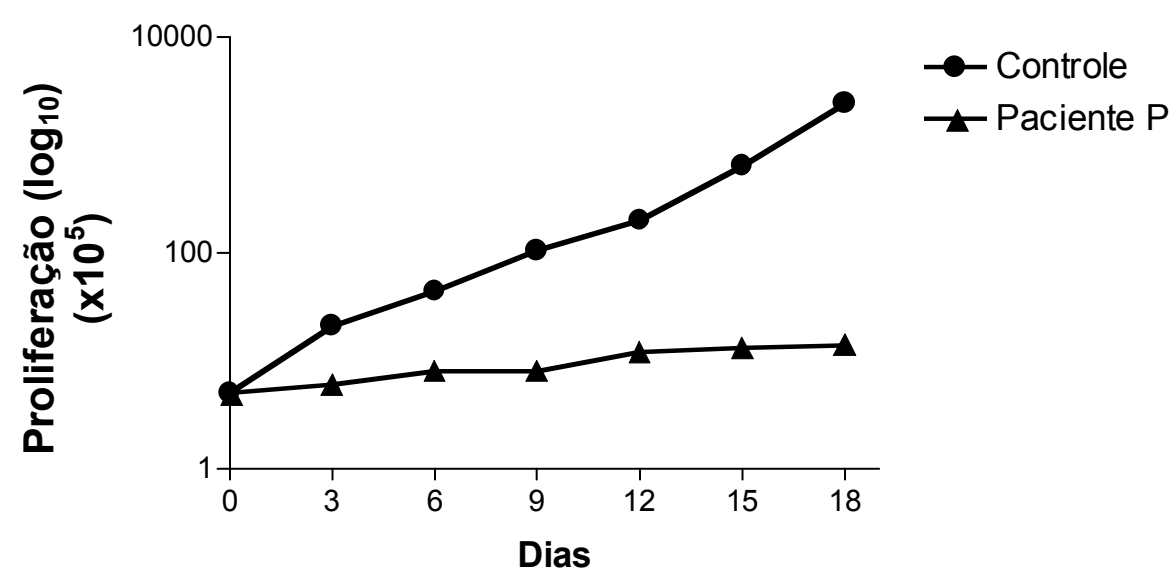

Figura 19: Cinética de proliferação das células imortalizadas do controle e da paciente $P$.

\subsection{Ensaios de estresse celular com brefeldina A para ativação da via UPR nos linfócitos B imortalizados com vírus Epstein-Barr}

Os ensaios de estresse com as células imortalizadas foram realizados da mesma forma como foi feito com as células ex vivo. Na figura 20 observamos a expressão de XBP-1 spliced nas células imortalizadas no estado basal e quando tratadas com brefeldina A por 8 ou 12 horas. Após 8 horas de tratamento, as células da paciente $\mathrm{P}$ e do controle expressaram, respectivamente, 17 e 42 vezes mais XBP-1 spliced em comparação àquelas não tratadas. Doze horas após, as células da paciente $\mathrm{P}$ expressaram 29 vezes mais XBP-1 spliced em relação ao estado basal; enquanto as células do controle apresentaram uma queda na expressão deste RNAm (14 vezes maior em relação ao estado basal). 


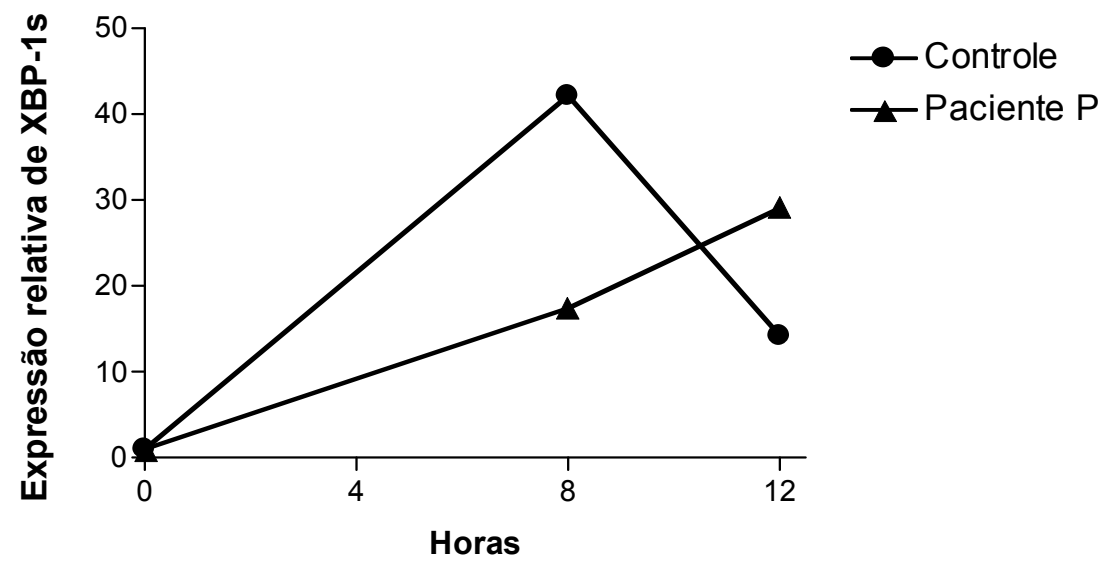

Figura 20: Expressão relativa de XBP-1s nos linfócitos $B$ imortalizados com EBV no estado basal e após tratamento com brefeldina A por 8 ou 12 horas.

$\mathrm{Na}$ figura 21 observamos a expressão relativa de IRE-1 $\alpha$ nas células imortalizadas da paciente $P$ e controle no estado basal e após 8 ou 12 horas de tratamento com brefeldina A. Após 8 horas de tratamento, as células da paciente P e do controle expressaram 5,3 e 6,1 vezes mais IRE-1 $\alpha$ em comparação ao estado basal. Após 12 horas, as células da paciente $P$ expressaram 8,1 vezes mais IRE-1 $\alpha$ que as células não tratadas; por sua vez, as células do controle apresentaram uma queda na expressão deste RNAm (apenas 2,2 vezes maior quando comparadas ao estado basal). 


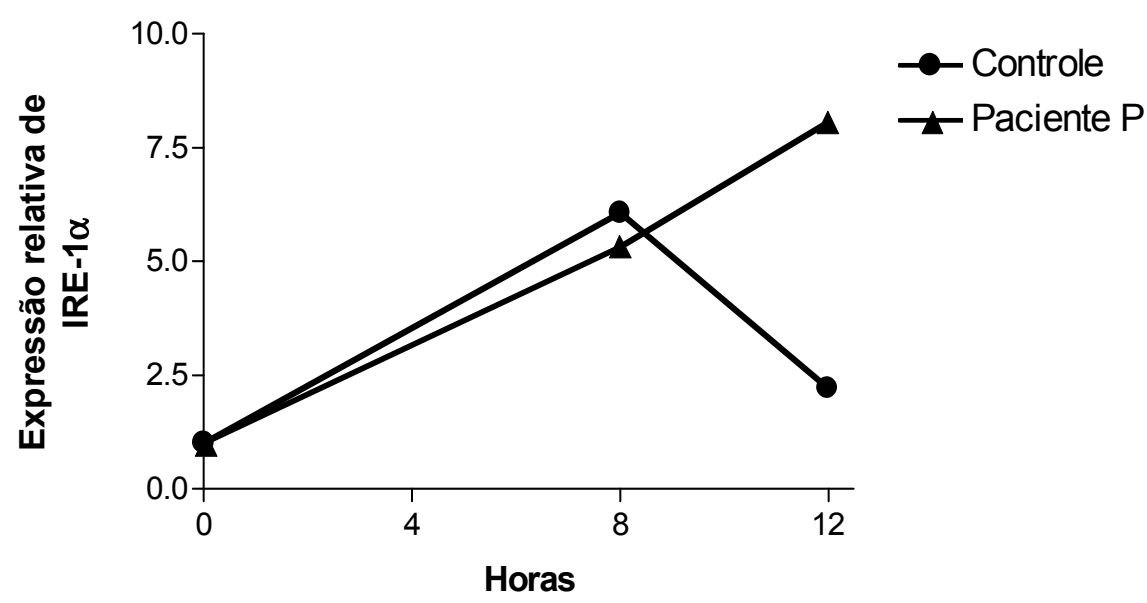

Figura 21: Expressão relativa de IRE-1 $\alpha$ nos linfócitos B imortalizados com EBV no estado basal e após tratamento com brefeldina A por 8 ou 12 horas.

$\mathrm{Na}$ figura 22 observamos a expressão relativa de BiP nas células imortalizadas da paciente $\mathrm{P}$ e controle no estado basal e após 8 ou 12 horas de tratamento com brefeldina A. Após 8 horas, as células da paciente $\mathrm{P}$ e do controle expressaram respectivamente, 4 e 27 vezes mais $\mathrm{BiP}$ em relação àquelas não tratadas. Doze horas após a adição de brefeldina A à cultura, as células da paciente P tiveram uma expressão de BiP 5 vezes maior em relação ao estado basal; enquanto as células do controle apresentaram uma queda na expressão deste RNAm (9 vezes maior quando comparadas ao estado basal).

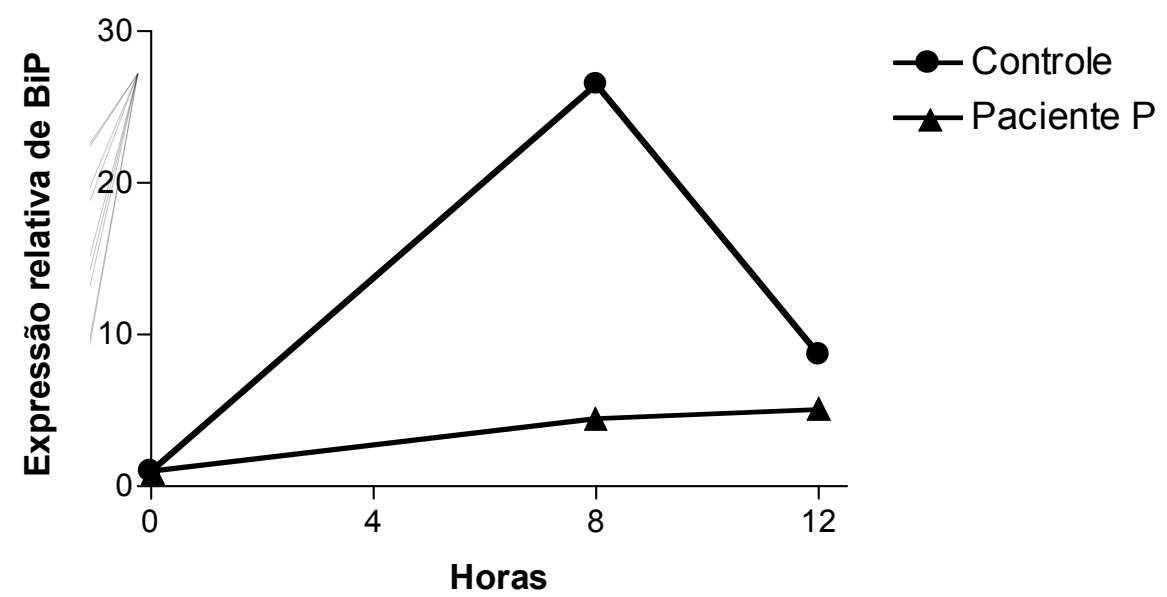


Figura 22: Expressão relativa de BiP nas células imortalizadas $B$ com EBV no estado basal e após tratamento com brefeldina A por 8 ou 12 horas.

Os experimentos de estresse celular com os linfócitos B imortalizados são ainda mais claros quanto à cinética de expressão gênica apresentada pelas células da paciente $\mathrm{P}$ e do controle (figuras 20, 21 e 22). Após 12 horas de tratamento com brefeldina $A$, as células da paciente $P$ ainda não atingiram a intensidade de expressão gênica alcançada pelas células do controle em 8 horas de tratamento. Estes dados nos permitem postular que os linfócitos $B$ da paciente $P$ apresentam uma ativação e resolução da via UPR mais lentos em relação ao controle.

\subsection{Diminuição do estresse celular de linfócitos B imortalizados com a utilização de chaperona química}

Realizamos também os ensaios com os linfócitos B imortalizados da paciente P e de um controle saudável utilizando DMSO por 8 horas. Na figura 23 observamos que o DMSO também induziu uma diminuição na expressão gênica de XBP-1s (figura 23A), IRE-1 $\alpha$ (figura 23B) e BiP (figura 23C).

Em concordância com os resultados observados no tratamento de células ex vivo, as células imortalizadas da paciente $\mathrm{P}$ apresentaram uma redução na expressão dos RNAm para XBP-1s, IRE-1 $1 \alpha$ e BiP após 8 horas de tratamento com DMSO. As células imortalizadas do controle também apresentaram diminuição na expressão destes genes, mas de forma menos acentuada. A redução da expressão gênica foi mais acentuada nas células imortalizadas provavelmente por se tratar de uma população homogênea de linfócitos B enquanto as células ex vivo apresentam outros tipos celulares. 
A)

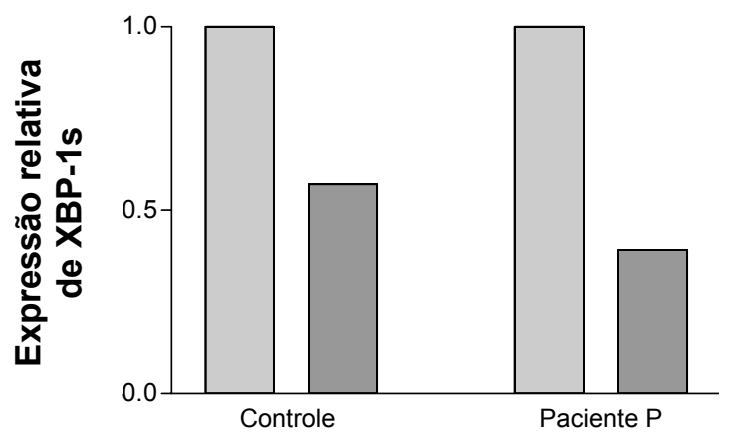

B)

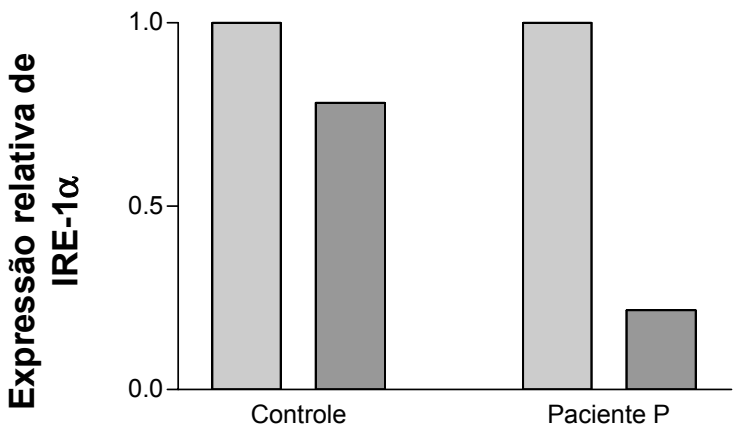

C)

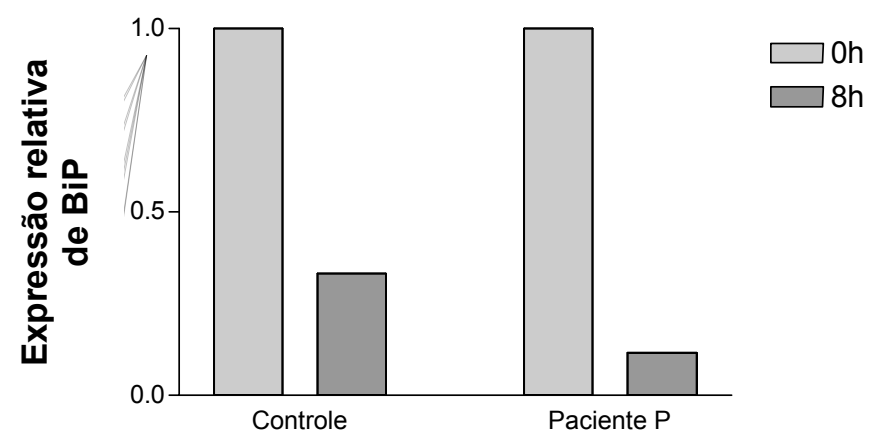

Figura 23: Expressão relativa dos RNAm para XBP-1 spliced (A), IRE-1 $\alpha$ (B) e BiP (C) nos linfócitos B imortalizados com EBV da paciente $\mathrm{P}$ e de um controle no estado basal (células ex vivo) ou após tratamento com DMSO por 8 horas.

4.12. Ensaio de estresse celular com LPS para ativação da via UPR nos linfócitos B imortalizados com o vírus Epstein-Barr

Alguns autores consideram o LPS uma substância capaz de estressar o RE e induzir a via UPR. Observamos, nos experimentos com células ex vivo da paciente $\mathrm{P}$ e de um controle saudável, que após 48 horas de tratamento com LPS a expressão gênica de XBP-1s, IRE-1 $\alpha$ e BiP estava diminuída em relação ao estado basal. Para 
verificar o potencial estressor do LPS, realizamos ensaios de tratamento com $10 \mu \mathrm{g} / \mathrm{ml}$ de LPS por 12 e 48 horas nas células imortalizadas.

Na figura 24 observamos que, com 48 horas, o efeito do LPS na expressão de XBP-1s, IRE-1 $\alpha$ e BiP foi semelhante àquele observado nas células ex vivo.

A)

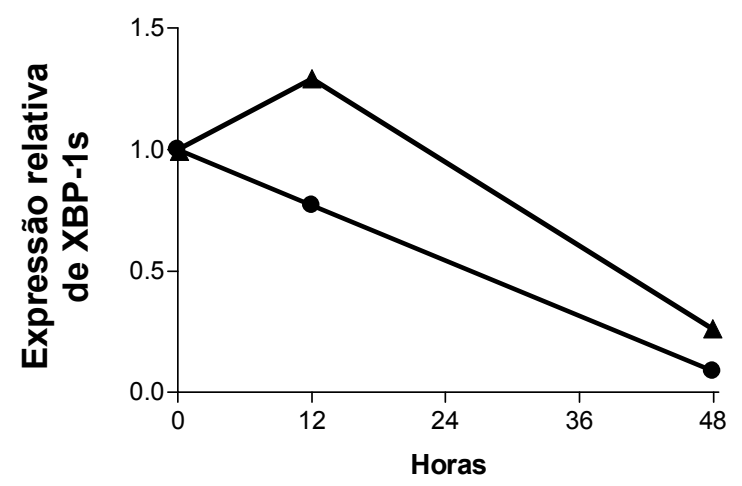

C)
B)

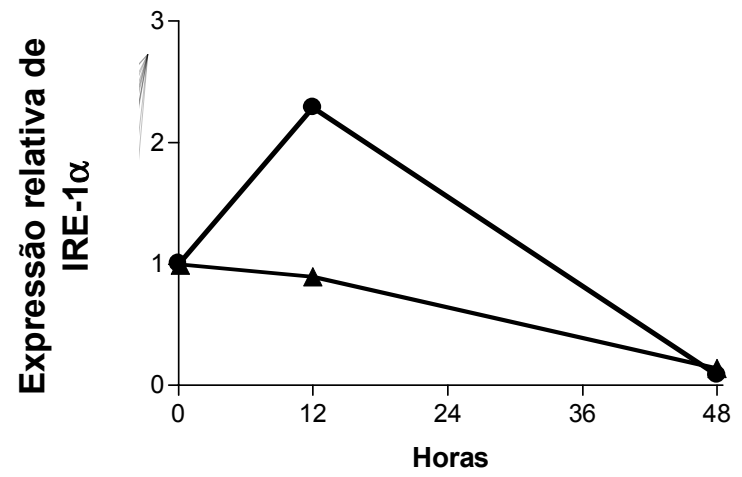

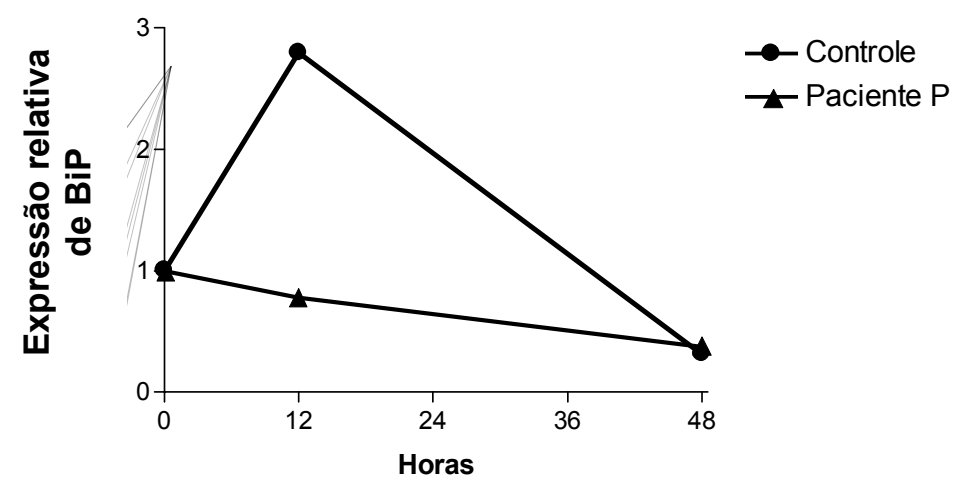

Figura 24: Expressão relativa dos RNAm para XBP-1 spliced (A), IRE-1 $\alpha$ (B) e BiP (C) nos linfócitos $B$ imortalizados com EBV da paciente $\mathrm{P}$ e de um controle no estado basal (células ex vivo) ou após tratamento com LPS por 12 ou 48 horas.

Interessantemente, após 12 horas de tratamento com LPS, as células da paciente $\mathrm{P}$ apresentaram um aumento na expressão de XBP-1s enquanto as células do controle apresentaram uma expressão praticamente inalterada de XBP-1s. A situação inversa foi observada para IRE-1 $\alpha$ e BiP, as células da paciente $P$ 
apresentaram expressão semelhante àquelas não tratadas enquanto as células do controle tiveram expressão aumentada destes genes.

Em nosso estudo, o desencadeamento da via UPR utilizando LPS não foi satisfatório. Alguns autores relataram que o tratamento com LPS é capaz de induzir o aumento da expressão de XBP-1s e BiP em 8 horas, atingindo um pico entre 48 e 72 horas (Skalet 2005; Zhang 2005). No entanto, os nossos achados mostraram o contrário: em 48 horas de tratamento já se observa a diminuição da expressão dos transcritos XBP-1s, IRE-1 $\alpha$ e BiP nas células ex vivo e imortalizadas.

Um grupo de pesquisadores mostrou que os transcritos de XBP-1s estão aumentados com 8 horas de tratamento e que os valores máximos de transcritos spliced foram alcançados em 48 horas em linfócitos B esplênicos de camundongos (Zhang 2005). Todavia, experimentos deste mesmo grupo utilizando LPS como substância estressora mostraram que, em 12 horas de tratamento, células de hepatoma murino apresentaram apenas 1,8 vezes mais $\mathrm{XBP}-1 \mathrm{~s}$ em relação ao estado basal. Esta ativação é fraca se comparada àquela alcançada no tratamento com brefeldina A pelo mesmo grupo: expressão oito vezes maior em relação ao estado basal após 12 horas de adição da droga à cultura (Zhang 2006).

Em outro trabalho de um grupo diferente, o tratamento com LPS de linfócitos B esplênicos de camundongo também induziu o aumento de transcritos XBP-1s e BiP, atingindo um pico em 72 horas (Skalet 2005).

Após 12 horas de tratamento com LPS, observamos expressão aumentada de IRE-1 $\alpha$ e BiP no controle e discretamente diminuída na paciente P. O inverso aconteceu com relação ao XBP-1s: ocorreu um aumento na paciente $\mathrm{P}$ e diminuição no controle. Estes resultados não se correlacionam àqueles obtidos nos tratamentos 
com brefeldina A, possivelmente por causa das diferenças da cinética de ação de cada estressor.

A diversidade de resultados obtidos por grupos diferentes nos permite dizer que o LPS constitui um estressor de RE capaz de desencadear a transcrição dos genes alvos da UPR. Entretanto, a intensidade da resposta e a cinética de expressão gênica são bastante variadas, talvez em decorrência dos diferentes tipos celulares utilizados nesses ensaios. Mais estudos são necessários para determinar a cinética de ação do LPS como estressor do RE e verificar a intensidade de resposta induzida por este agente.

\subsection{Seqüenciamento do RNAm da IRE-1 $\alpha$ da paciente $P$}

Nosso próximo passo foi analisar a presença de mutações no ire-1a nos domínios quinase e ribonuclease. Estes domínios são particularmente importantes na indução da via UPR e conseqüente splicing do XBP-1 (Kimata 2004; Zhang 2005).

Uma vez desencadeado o estresse do RE, a BiP se desliga do domínio luminal da IRE-1 $\alpha$, deixando-a livre para oligomerizar com outras moléculas IRE- $1 \alpha$. Os domínios quinases sofrem trans-autofosforilação e ativam a função ribonuclease da IRE-1 $\alpha$. O seqüenciamento mostrou-nos que a paciente $P$ não apresenta mutações nestes domínios (figuras 25 A e B). 
A)

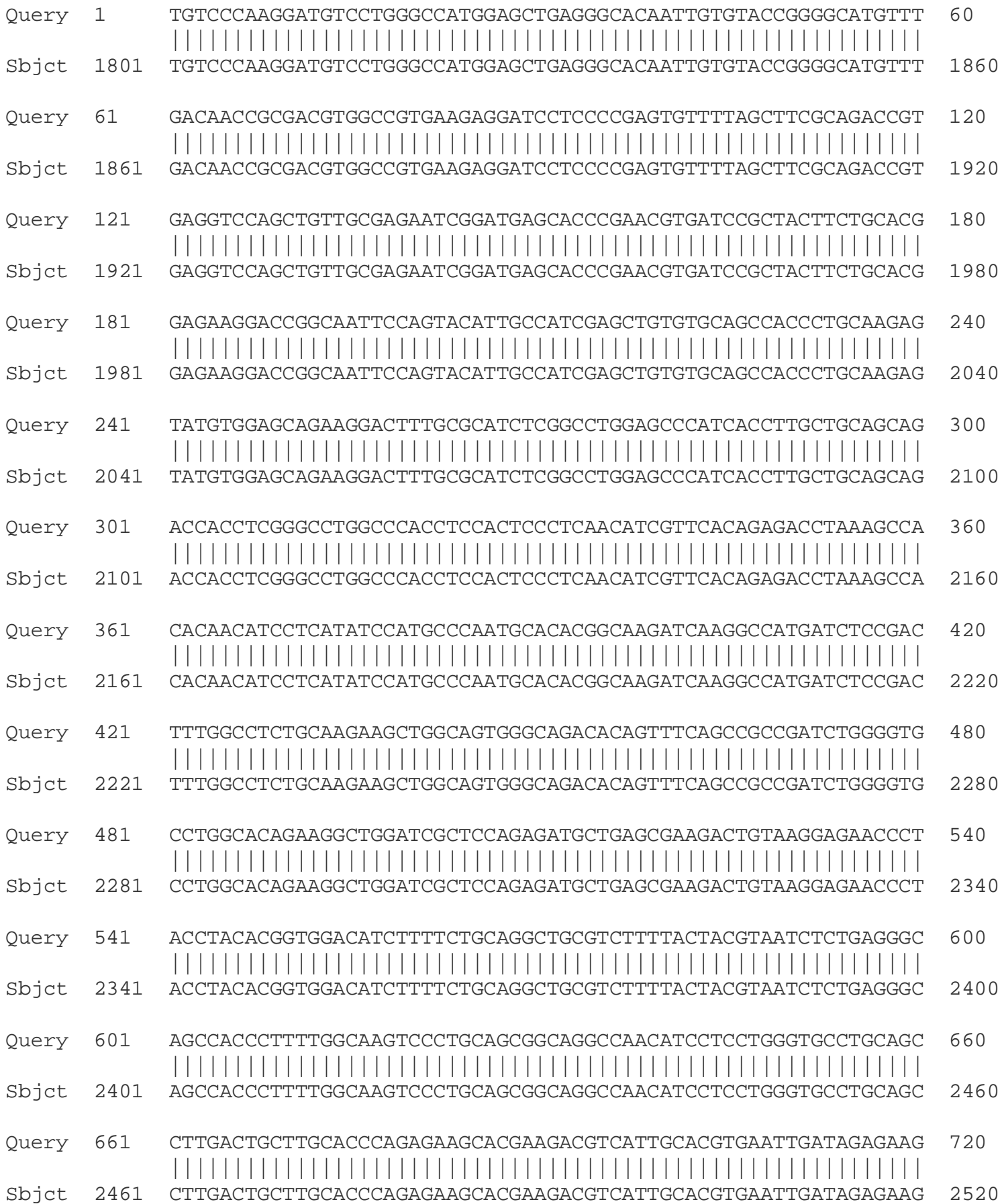


B)

\begin{tabular}{|c|c|c|c|}
\hline Query & 781 & TTCTGGAGCCTAGAGAAGCAGCTCCAGTTCTTCCAGGACGTGAGCGACAGAATAGAAAAG & 840 \\
\hline Sbjet & 2581 & | | | | | | | | | | | | | | | | | | | | | | | | | | | | | | | | | | | | | | | | | | | | | | | | | | | | | | | | | | | | | | | | | | | | | | & 2640 \\
\hline uery & 841 & GAATCCCTGGATGGCCCGATCGTGAAGCAGTTAGAGAGAGGCGGGAGAGCCGTGGTGAAG & 900 \\
\hline ojct & 2641 & GAATCCCTGGATGGCCCGATCGTGAAGCAGTTAGAGAGAGGCGGGAGAGCCGTGGTGAAG & 2700 \\
\hline dery & 901 & ATGGACTGGCGGGAGAACATCACTGTCCCCCTCCAGACAGACCTGCGTAAATTCAGGACC & 960 \\
\hline ojet & 2701 & | | | | | | | | | | | | | | | | | | | | | | | | | | | | | | | | | | | | | | | | | | | | | | | | | | | | | | | | | | | | | | | | | | | | | | & 2760 \\
\hline dery & 961 & TATAAAGGTGGTTCTGTCAGAGATCTCCTCCGAGCCATGAGAAATAAGAAGCACCACTAC & 1020 \\
\hline ojct & 2761 & TATAAAGGTGGTTCTGTCAGAGATCTCCTCCGAGCCATGAGAAATAAGAAGCACCACTAC & 2820 \\
\hline dery & 1021 & CGGGAGCTGCCTGCAGAGGTGCGGGAGACGCTGGGGTCCCTCCCCGACGACTTCGTGTGC & 1080 \\
\hline ojct & 2821 & CGGGAGCTGCCTGCAGAGGTGCGGGAGACGCTGGGGTCCCTCCCCGACGACTTCGTGTGC & 2880 \\
\hline uery & 1081 & TACTTCACGTCTCGCTTCCCCCACCTCCTCGCACACACCTACCGGGCCATGGAGCTGTGC & 1140 \\
\hline ojct & 2881 & TACTTCACGTCTCGCTTCCCCCACCTCCTCGCACACACCTACCGGGCCATGGAGCTGTGC & 2940 \\
\hline Query & 1141 & AGCCACGAGAGACTCTTCCAGCCCTACTACTTCCACGAGCCCCCAGAGCCCCAGCCCCCA & 1200 \\
\hline ojct & 2941 & AGCCACGAGAGACTCTTCCAGCCCTACTACTTCCACGAGCCCCCAGAGCCCCAGCCCCCA & 3000 \\
\hline dery & 1201 & ACTCCAGACGCCCTCTGAGCGAGGGCGGCCCCTCTGTTCTGGTGGCCCCAGCTGTGA & 1260 \\
\hline & 3001 & 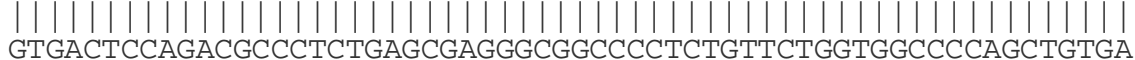 & 060 \\
\hline
\end{tabular}

Figura 25: Seqüenciamento dos domínios quinase e ribonuclease da IRE-1 $\alpha$. A) Seqüência alinhada com a seqüência do domínio quinase depositada no GenBank. B) Seqüência alinhada com a seqüência do domínio ribonuclease depositada no GenBank (gi: 37544107).

Considerando a paciente $\mathrm{P}$ como um caso único, não podemos sugerir que o splicing diminuído do RNAm XBP-1 em associação ao acúmulo de IgM no RE é causa da CVID. No entanto, nós especulamos a possibilidade da existência de um mecanismo ligado a via UPR que possa ser gerador da hipogamaglobulinemia em 
um subgrupo de pacientes com CVID. Os dados aqui apresentados fornecem a primeira evidência que a manutenção da homeostasia do RE nas células secretoras de imunoglobulinas humanas depende da via UPR e que a interrupção desta via correlaciona-se com a ausência de imunoglobulinas circulantes.

Recentemente, Taubenheim (2005) e colaboradores sugeriram que a CVID não poderia ser causada por um defeito no gene xbp-1 porque o mesmo é crucial para a maturação terminal de linfócitos B e qualquer defeito poderia ser letal. Nossos dados estão em concordância com esta suposição, já que as células da paciente P apresentam XBP-1 spliced, mesmo que em baixas quantidades. Considerando esta hipótese e correlacionando com os nossos dados, elaboramos o modelo abaixo (figura 26). Neste modelo consideramos que a expressão diminuída de XBP-1 spliced é devido a um defeito no braço IRE-1/XBP-1 da via UPR, levando a um resgate mais lento da homeostasia do RE após um estresse, baixas taxas de dobramento e exportação de imunoglobulinas. 
A)

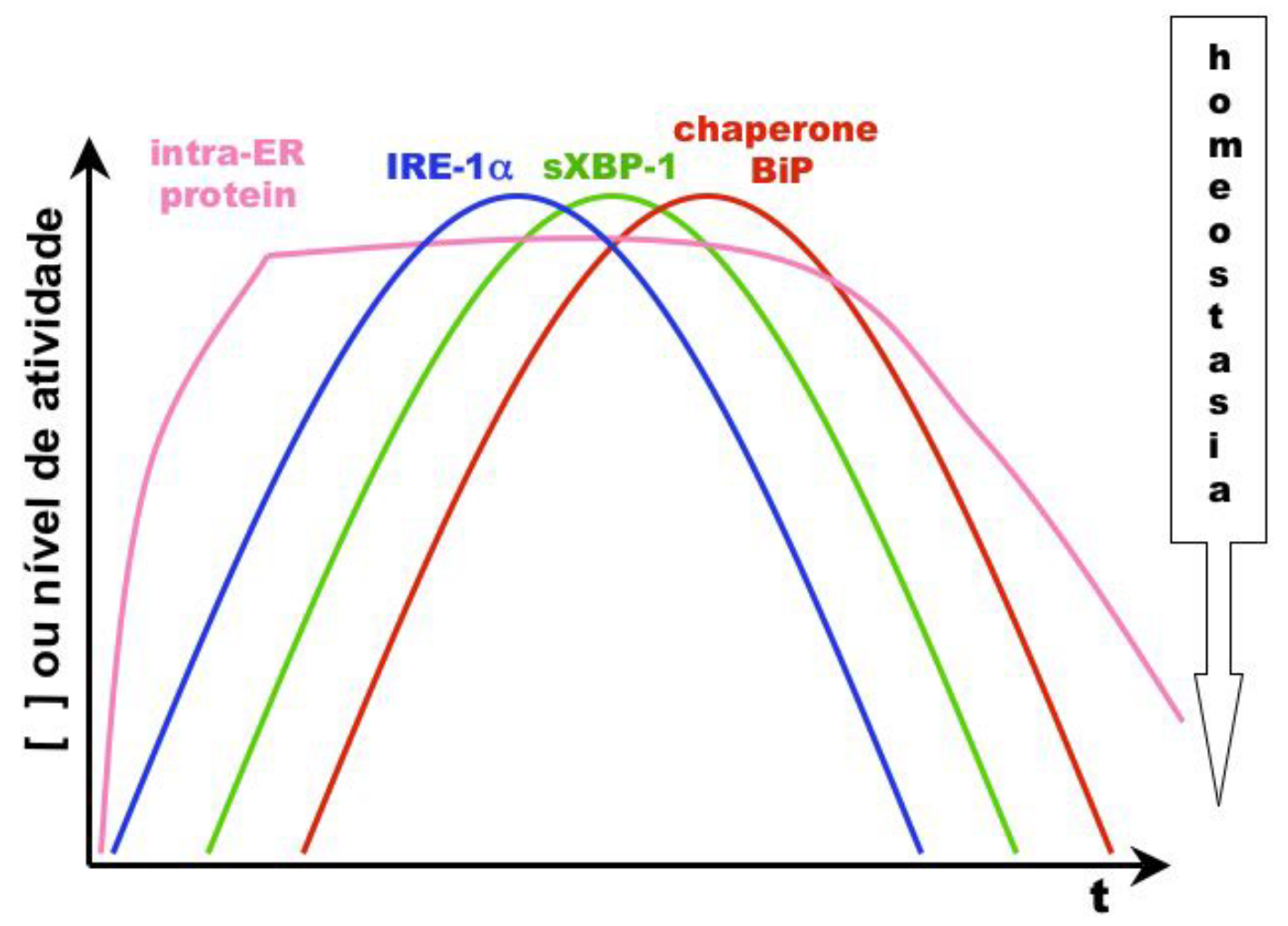


B)

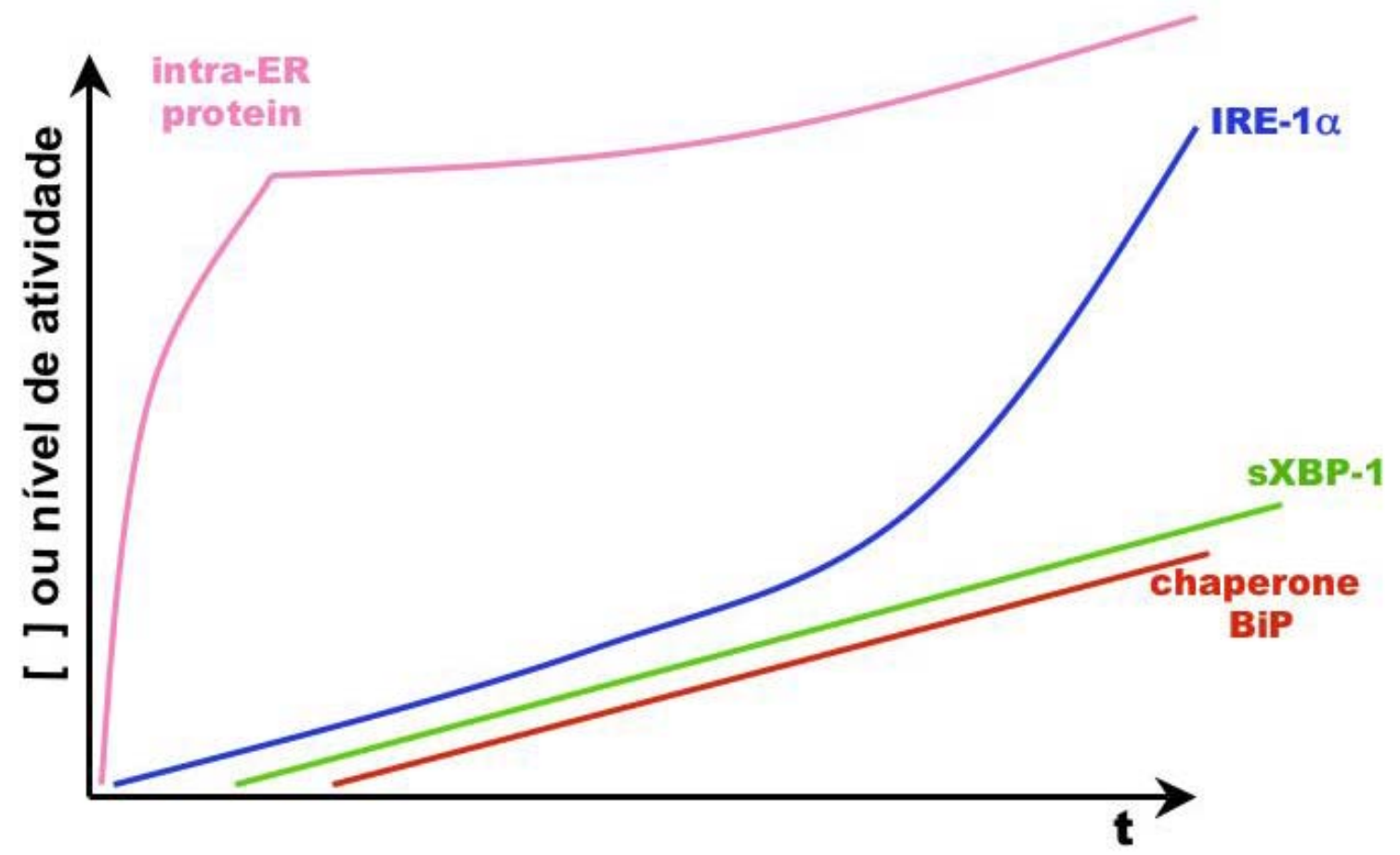

Figura 26: A) Modelo proposto para a sinalização da via UPR na regulação da homeostasia do retículo endoplasmático após o aumento na síntese de proteínas. B) Modelo proposto para a ausência de homeostasia do retículo endoplasmático apresentada pelos linfócitos $B$ da paciente $P$. 


\section{CONCLUSÕES}

Nossos achados associam o splicing diminuído do RNAm XBP-1 ao acúmulo de IgM no retículo endoplasmático e baixas taxas de transcrição de chaperonas nos linfócitos $B$ da paciente $P$. Estes resultados provêm um mecanismo para explicar a hipogamaglobulinemia observada nesta paciente.

Nossos dados sustentam a possibilidade de que a hipogamaglobulinemia apresentada por um subgrupo de pacientes com CVID possa ser resultante de uma patologia de proteínas mal-dobradas. 


\section{REFERÊNCIAS BIBLIOGRÁFICAS}

Agematsu, K., Futatani, T., Hokibara, S., Kobayashi, N., Takamoto, M., Tsukada, S., Suzuki, H., Koyasu, S., Miyawaki, T., Sugane, K., Komiyama, A., Ochs, H. D. (2002). "Absence of memory $B$ cells in patients with common variable immunodeficiency." Clin Immunol 103(1): 34-42.

Amoras, A. L., Kanegane, H., Miyawaki, T., Vilela, M. M. (2003). "Defective Fc-, CR1and CR3-mediated monocyte phagocytosis and chemotaxis in common variable immunodeficiency and X-linked agammaglobulinemia patients." $\underline{\mathrm{J}}$ Investig Allergol Clin Immunol 13(3): 181-8.

Aspalter, R. M., Sewell, W. A., Dolman, K., Farrant, J., Webster, A. D. (2000). "Deficiency in circulating natural killer (NK) cell subsets in common variable immunodeficiency and X-linked agammaglobulinaemia." Clin Exp Immunol 121(3): 506-14.

Aukrust, P., Muller, F., Froland, S. S. (1994). "Enhanced generation of reactive oxygen species in monocytes from patients with common variable immunodeficiency." Clin Exp Immunol 97(2): 232-8.

Baracho, G. V. (2006). Aspectos moleculares da Imunodeficiencia Comum Variavel: papel de X-box binding protein 1 (XBP-1), um fator de transcriçao essencial na diferenciaçao de plasmocitos. Imunologia. Sao Paulo, Universidade de Sao Paulo: 123.

Barral, J. M., Broadley, S. A., Schaffar, G., Hartl, F. U. (2004). "Roles of molecular chaperones in protein misfolding diseases." Semin Cell Dev Biol 15(1): 17-29.

Bayry, J., Hermine, O., Webster, D. A., Levy, Y., Kaveri, S. V. (2005). "Common variable immunodeficiency: the immune system in chaos." Trends Mol Med 11(8): 370-6.

Bayry, J., Lacroix-Desmazes, S., Kazatchkine, M. D., Galicier, L., Lepelletier, Y., Webster, D., Levy, Y., Eibl, M. M., Oksenhendler, E., Hermine, O., Kaveri, S. V. (2004). "Common variable immunodeficiency is associated with defective functions of dendritic cells." Blood 104(8): 2441-3.

Bernier, V., Lagace, M., Bichet, D. G., Bouvier, M. (2004). "Pharmacological chaperones: potential treatment for conformational diseases." Trends Endocrinol Metab 15(5): 222-8. 
Boyce, M., Yuan, J. (2006). "Cellular response to endoplasmic reticulum stress: a matter of life or death." Cell Death Differ 13(3): 363-73.

Brewer, J. W., Hendershot, L. M. (2005). "Building an antibody factory: a job for the unfolded protein response." Nat Immunol 6(1): 23-9.

Brooks, D. A. (1999). "Introduction: molecular chaperones of the ER: their role in protein folding and genetic disease." Semin Cell Dev Biol 10(5): 441-442.

Bross, P., Gregersen, N. (2003). Protein Misfolding and Disease. Totowa, New Jersey, Humana Press Inc.

Brown, C. R., Hong-Brown, L. Q., Biwersi, J., Verkman, A. S., Welch, W. J. (1996). "Chemical chaperones correct the mutant phenotype of the delta F508 cystic fibrosis transmembrane conductance regulator protein." $\underline{\text { Cell Stress }}$ Chaperones 1(2): 117-25.

Buckley, R. H. (2004). "Pulmonary complications of primary immunodeficiencies." Paediatr Respir Rev 5 Suppl A: S225-33.

Calfon, M., Zeng, H., Urano, F., Till, J. H., Hubbard, S. R., Harding, H. P., Clark, S. G., Ron, D. (2002). "IRE1 couples endoplasmic reticulum load to secretory capacity by processing the XBP-1 mRNA." Nature 415(6867): 92-6.

Carsetti, R., Rosado, M. M., Donnanno, S., Guazzi, V., Soresina, A., Meini, A., Plebani, A., Aiuti, F., Quinti, I. (2005). "The loss of IgM memory B cells correlates with clinical disease in common variable immunodeficiency." $\underline{\mathrm{J}}$ Allergy Clin Immunol 115(2): 412-7.

Castigli, E., Wilson, S. A., Garibyan, L., Rachid, R., Bonilla, F., Schneider, L., Geha, R. S. (2005). "TACI is mutant in common variable immunodeficiency and IgA deficiency." Nat Genet 37(8): 829-34.

Clauss, I. M., Gravallese, E. M., Darling, J. M., Shapiro, F., Glimcher, M. J. Glimcher, L. H. (1993). "In situ hybridization studies suggest a role for the basic regionleucine zipper protein hXBP-1 in exocrine gland and skeletal development during mouse embryogenesis." Dev Dyn 197(2): 146-156.

Cunningham-Rundles, C. (1989). "Clinical and immunologic analyses of 103 patients with common variable immunodeficiency." J Clin Immunol 9(1): 22-33.

Cunningham-Rundles, C., Bodian, C. (1999). "Common variable immunodeficiency: clinical and immunological features of 248 patients." Clin Immunol 92(1): 3448. 
Cunningham-Rundles, C., Radigan, L. (2005a). "Deficient IL-12 and dendritic cell function in common variable immune deficiency." Clin Immunol 115(2): 14753.

Farrington, M., Grosmaire, L. S., Nonoyama, S., Fischer, S. H., Hollenbaugh, D., Ledbetter, J. A., Noelle, R. J., Aruffo, A., Ochs, H. D. (1994). "CD40 ligand expression is defective in a subset of patients with common variable immunodeficiency." Proc Natl Acad Sci U S A 91(3): 1099-103.

Fischer, A. (2004). "Human primary immunodeficiency diseases: a perspective." Immunol 5(1): 23-30.

Funauchi, M., Farrant, J., Moreno, C., Webster, A. D. (1995). "Defects in antigendriven lymphocyte responses in common variable immunodeficiency (CVID) are due to a reduction in the number of antigen-specific CD4+ T cells." $\underline{\text { Clin }}$ Exp Immunol 101(1): 82-8.

Gass, J. N., Gifford, N. M., Brewer, J. W. (2002). "Activation of an unfolded protein response during differentiation of antibody-secreting B cells." $\mathrm{J}$ Biol Chem 277(50): 49047-54.

Gass, J. N., Gunn, K. E., Sriburi, R., Brewer, J. W. (2004). "Stressed-out B cells? Plasma-cell differentiation and the unfolded protein response." Trends Immunol 25(1): 17-24.

Gunn, K. E., Gifford, N. M., Mori, K., Brewer, J. W. (2004). "A role for the unfolded protein response in optimizing antibody secretion." Mol Immunol 41(9): 91927.

Guo, B. C., Saxon, A. (1995). "B cell lines from a subset of patients with common variable immunodeficiency undergo enhanced apoptosis associated with an increased display of CD95 (Apo-1/fas), diminished CD38 expression, and decreased IgG and IgA production." Cell Immunol 166(1): 83-92.

Harding, H. P., Zhang, Y., Ron, D. (1999). "Protein translation and folding are coupled by an endoplasmic-reticulum-resident kinase." Nature 397(6716): 271-274.

Hendershot, L. M. (2004). "The ER function BiP is a master regulator of ER function." Mt Sinai J Med 71(5): 289-297.

Iwakoshi, N. N., Lee, A. H., Vallabhajosyula, P., Otipoby, K. L., Rajewsky, K., Glimcher, L. H. (2003a). "Plasma cell differentiation and the unfolded protein response intersect at the transcription factor XBP-1." Nat Immunol 4(4): 321-9. 
Johnson, M. L., Keeton, L. G., Zhu, Z. B., Volanakis, J. E., Cooper, M. D., Schroeder, H. W., Jr. (1997). "Age-related changes in serum immunoglobulins in patients with familial IgA deficiency and common variable immunodeficiency (CVID)." Clin Exp Immunol 108(3): 477-483.

Kainulainen, L., Nikoskelainen, J., Ruuskanen, O. (2001). "Diagnostic findings in 95 Finnish patients with common variable immunodeficiency." $\mathrm{J}$ Clin Immunol 21(2): 145-9.

Kaneko, H., Kawamoto, N., Asano, T., Mabuchi, Y., Horikoshi, H., Teramoto, T.,Matsui, E., Kondo, M., Fukao, T., Kasahara, K., Kondo, N. (2005). "Leaky phenotype of X-linked agammaglobulinaemia in a Japanese family." Clin Exp Immunol 140(3): 520-523.

Kaufman, R. J. (1999). "Stress signaling from the lumen of the endoplasmic reticulum: coordination of gene transcriptional and translational controls." Genes Dev 13(10): 1211-33.

Kimata, Y., Oikawa, D., Shimizu, Y., Ishiwata-Kimata, Y., Kohno, K. (2004). "A role for $\mathrm{BiP}$ as an adjustor for the endoplasmic reticulum stress-sensing protein Ire1." J Cell Biol 167(3): 445-56.

Kokron, C. M., Errante, P. R., Barros, M. T., Baracho, G. V., Camargo, M. M., Kalil, J., Rizzo, L. V. (2004). "Clinical and laboratory aspects of common variable immunodeficiency." An Acad Bras Cienc 76(4): 707-726.

Kondratenko, I., Amlot, P. L., Webster, A. D., Farrant, J. (1997). "Lack of specific antibody response in common variable immunodeficiency (CVID) associated with failure in production of antigen-specific memory $T$ cells. MRC Immunodeficiency Group." Clin Exp Immunol 108(1): 9-13.

Kruetzmann, S., Rosado, M. M., Weber, H., Germing, U., Tournilhac, O., Peter, H. H., Berner, R., Peters, A., Boehm, T., Plebani, A., Quinti, I., Carsetti, R. (2003). "Human immunoglobulin M memory B cells controlling Streptococcus pneumoniae infections are generated in the spleen." J Exp Med 197(7): 93945.

Kruger, G., Welte, K., Ciobanu, N., Cunningham-Rundles, C., Ralph, P., Venuta, S., Feldman, S., Koziner, B., Wang, C. Y., Moore, M. A., et al., (1984). "Interleukin-2 correction of defective in vitro T-cell mitogenesis in patients with common varied immunodeficiency." J Clin Immunol 4(4): 295-303. 
Lee, A. H., Iwakoshi, N. N., Anderson, K. C., Glimcher, L. H. (2003a). "Proteasome inhibitors disrupt the unfolded protein response in myeloma cells." Proc Natl Acad Sci U S A 100(17): 9946-51.

Lee, A. H., Iwakoshi, N. N., Glimcher, L. H. (2003b). "XBP-1 regulates a subset of endoplasmic reticulum resident chaperone genes in the unfolded protein response." Mol Cell Biol 23(21): 7448-59.

Lee, K., Tirasophon, W., Shen, X., Michalak, M., Prywes, R., Okada, T., Yoshida, H., Mori, K., Kaufman, R. J. (2002). "IRE1-mediated unconventional mRNA splicing and S2P-mediated ATF6 cleavage merge to regulate XBP1 in signaling the unfolded protein response." Genes Dev 16(4): 452-66.

Livak, K. J., Schmittgen, T. D. (2001). "Analysis of relative gene expression data using real-time quantitative PCR and the 2(-Delta Delta $\mathrm{C}(\mathrm{T})$ ) Method." Methods 25(4): 402-8.

Ma, Y., Hendershot, L. M. (2003). "The stressful road to antibody secretion." Nat Immunol 4(4): 310-1.

McHeyzer-Williams, M. G., Ahmed, R. (1999). "B cell memory and the long-lived plasma cell." Curr Opin Immunol 11(2): 172-9.

Middleton, T., Gahn, T. A., Martin, J. M., Sugden, B. (1991). "Immortalizing genes of Epstein-Barr virus." Adv Virus Res 40: 19-55.

Miller, S. G., Carnell, L., Moore, H. H. (1992). "Post-Golgi membrane traffic: brefeldin A inhibits export from distal Golgi compartments to the cell surface but not recycling." J Cell Biol 118(2): 267-83.

Nakagawa, T., Zhu, H., Morishima, N., Li, E., Xu, J., Yankner, B. A., Yuan, J. (2000). "Caspase-12 mediates endoplasmic-reticulum-specific apoptosis and cytotoxicity by amyloid-beta." Nature 403(6765): 98-103.

Nijenhuis, T., Klasen, I., Weemaes, C. M., Preijers, F., de Vries, E., van der Meer, J. W. (2001). "Common variable immunodeficiency (CVID) in a family: an autosomal dominant mode of inheritance." Neth J Med 59(3): 134-9.

Ozcan, U., Cao, Q., Yilmaz, E., Lee, A. H., Iwakoshi, N. N., Ozdelen, E., Tuncman, G., Gorgun, C., Glimcher, L. H., Hotamisligil, G. S. (2004). "Endoplasmic reticulum stress links obesity, insulin action, and type 2 diabetes." Science 306(5695): 457-61.

Ozcan, U., Yilmaz, E., Ozcan, L., Furuhashi, M., Vaillancourt, E., Smith, R. O., Gorgun, C. Z., Hotamisligil, G. S. (2006). "Chemical chaperones reduce ER 
stress and restore glucose homeostasis in a mouse model of type 2 diabetes." Science 313(5790): 1137-40.

Reimold, A. M., Iwakoshi, N. N., Manis, J., Vallabhajosyula, P., Szomolanyi-Tsuda, E., Gravallese, E. M., Friend, D., Grusby, M. J., Alt, F., Glimcher, L. H. (2001). "Plasma cell differentiation requires the transcription factor XBP-1." Nature 412(6844): 300-7.

Rutkowski, D. T., Kaufman, R. J. (2004). "A trip to the ER: coping with stress." Trends Cell Biol 14(1): 20-8.

Salzer, U., Chapel, H. M., Webster, A. D., Pan-Hammarstrom, Q., Schmitt-Graeff, A., Schlesier, M., Peter, H. H., Rockstroh, J. K., Schneider, P., Schaffer, A. A., Hammarstrom, L., Grimbacher, B. (2005). "Mutations in TNFRSF13B encoding TACl are associated with common variable immunodeficiency in humans." Nat Genet 37(8): 820-828.

Salzer, U., Grimbacher, B. (2006a). "Monogenetic defects in common variable immunodeficiency: what can we learn about terminal B cell differentiation?" Curr Opin Rheumatol 18(4): 377-82.

Salzer, U., Maul-Pavicic, A., Cunningham-Rundles, C., Urschel, S., Belohradsky, B. H., Litzman, J., Holm, A., Franco, J. L., Plebani, A., Hammarstrom, L., Skrabl, A., Schwinger, W., Grimbacher, B. (2004). "ICOS deficiency in patients with common variable immunodeficiency." Clin Immunol 113(3): 234-40.

Saxon, A., Sidell, N., Zhang, K. (1992). "B cells from subjects with CVI can be driven to Ig production in response to CD40 stimulation." Cell Immunol 144(1): 16981.

Schwartz, R., Porat, Y. B., Handzel, Z., Sthoeger, Z., Garty, B. Z., Confino-Cohen, R., Levy, J., Zan-Bar, I. (1999). "Identification of a subset of common variable immunodeficiency patients with impaired B-cell protein tyrosine phosphorylation." Clin Diagn Lab Immunol 6(6): 856-860.

Seggev, J. S. (1991). "Spontaneous remission of common variable immunodeficiency of 20 years duration." J Allergy Clin Immunol 88(3 Pt 1): 418-20.

Seligmann, M., Aucouturier, P., Danon, F., Preud'Homme, J. L. (1991). "Changes in serum immunoglobulin patterns in adults with common variable immunodeficiency." Clin Exp Immunol 84(1): 23-7.

Shaffer, A. L., Shapiro-Shelef, M., Iwakoshi, N. N., Lee, A. H., Qian, S. B., Zhao, H., Yu, X., Yang, L., Tan, B. K., Rosenwald, A., Hurt, E. M., Petroulakis, E., 
Sonenberg, N., Yewdell, J. W., Calame, K., Glimcher, L. H., Staudt, L. M. (2004). "XBP1, downstream of Blimp-1, expands the secretory apparatus and other organelles, and increases protein synthesis in plasma cell differentiation." Immunity 21(1): 81-93.

Skalet, A. H., Isler, J. A., King, L. B., Harding, H. P., Ron, D., Monroe, J. G. (2005). "Rapid B cell receptor-induced unfolded protein response in nonsecretory $B$

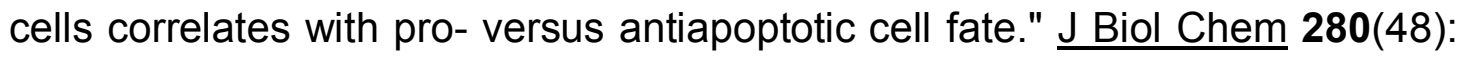
39762-71.

Sneller, M. C. (2001). "Common variable immunodeficiency." Am J Med Sci 321(1): 42-8.

Spickett, G. P., Matamoros, N., Farrant, J. (1992). "Lymphocyte surface phenotype in common variable immunodeficiency." Dis Markers 10(2): 67-80.

Spickett, G. P., Webster, A. D., Farrant, J. (1990). "Cellular abnormalities in common variable immunodeficiency." Immunodefic Rev 2(3): 199-219.

Taubenheim, N., von Hornung, M., Durandy, A., Warnatz, K., Corcoran, L., Peter, H. H., Eibel, H. (2005). "Defined blocks in terminal plasma cell differentiation of common variable immunodeficiency patients." J Immunol 175(8): 5498-5503.

Tiller, T. L. J., Liddle, K. J. (2000). "Immunodeficiency problems in children." J S C Med Assoc 96(5): 225-8.

Tirosh, B., Iwakoshi, N. N., Glimcher, L. H., Ploegh, H. L. (2005b). "Rapid turnover of unspliced XBP-1 as a factor that modulates the unfolded protein response." $\underline{J}$ Biol Chem.

Travers, K. J., Patil, C. K., Wodicka, L., Lockhart, D. J., Weissman, J. S., Walter, P. (2000). "Functional and genomic analyses reveal an essential coordination between the unfolded protein response and ER-associated degradation." Cell 101(3): 249-58.

Turner, G. C., Varshavsky, A. (2000). "Detecting and measuring cotranslational protein degradation in vivo." Science 289(5487): 2117-20.

Urano, F., Wang, X., Bertolotti, A., Zhang, Y., Chung, P., Harding, H. P., Ron, D. (2000). "Coupling of stress in the ER to activation of JNK protein kinases by transmembrane protein kinase IRE1." Science 287(5453): 664-666.

van Anken, E., Romijn, E. P., Maggioni, C., Mezghrani, A., Sitia, R., Braakman, I., Heck, A. J. (2003). "Sequential waves of functionally related proteins are 
expressed when B cells prepare for antibody secretion." Immunity 18(2): 24353.

van Zelm, M. C., Reisli, I., van der Burg, M., Castano, D., van Noesel, C. J., van Tol, M. J., Woellner, C., Grimbacher, B., Patino, P. J., van Dongen, J. J., Franco, J. L. (2006). "An antibody-deficiency syndrome due to mutations in the CD19 gene." N Engl J Med 354(18): 1901-12.

Vorechovsky, I., Webster, A. D., Plebani, A., Hammarstrom, L. (1999). "Genetic linkage of IgA deficiency to the major histocompatibility complex: evidence for allele segregation distortion, parent-of-origin penetrance differences, and the role of anti-lgA antibodies in disease predisposition." Am J Hum Genet 64(4): 1096-109.

Washington, K., Stenzel, T. T., Buckley, R. H., Gottfried, M. R. (1996). "Gastrointestinal pathology in patients with common variable immunodeficiency and X-linked agammaglobulinemia." Am J Surg Pathol 20(10): 1240-52.

Welch, W. J., Brown, C. R. (1996). "Influence of molecular and chemical chaperones on protein folding." Cell Stress Chaperones 1(2): 109-15.

Weller, S., Braun, M. C., Tan, B. K., Rosenwald, A., Cordier, C., Conley, M. E., Plebani, A., Kumararatne, D. S., Bonnet, D., Tournilhac, O., Tchernia, G., Steiniger, B., Staudt, L. M., Casanova, J. L., Reynaud, C. A., Weill, J. C. (2004). "Human blood IgM "memory" B cells are circulating splenic marginal zone B cells harboring a prediversified immunoglobulin repertoire." Blood 104(12): 3647-54.

Wu, J., Kaufman, R. J. (2006). "From acute ER stress to physiological roles of the Unfolded Protein Response." Cell Death Differ 13(3): 374-84.

Yoshida, H., Matsui, T., Hosokawa, N., Kaufman, R. J., Nagata, K., Mori, K. (2003). "A time-dependent phase shift in the mammalian unfolded protein response." Dev Cell 4(2): 265-71.

Yoshida, H., Matsui, T., Yamamoto, A., Okada, T., Mori, K. (2001). "XBP1 mRNA is induced by ATF6 and spliced by IRE1 in response to ER stress to produce a highly active transcription factor." Cell 107: 881-891.

Yoshida, H., Okada, T., Haze, K., Yanagi, H., Yura, T., Negishi, M., Mori, K. (2000). "ATF6 activated by proteolysis binds in the presence of NF-Y (CBF) directly to 
the cis-acting element responsible for the mammalian unfolded protein response." Mol Cell Biol 20(18): 6755-6767.

Yoshida, H., Oku, M., Suzuki, M., Mori, K. (2006). "pXBP1(U) encoded in XBP1 premRNA negatively regulates unfolded protein response activator $\mathrm{pXBP} 1(\mathrm{~S})$ in mammalian ER stress response." J Cell Biol 172(4): 565-75.

Zhang, K., Shen, X., Wu, J., Sakaki, K., Saunders, T., Rutkowski, D. T., Back, S. H., Kaufman, R. J. (2006). "Endoplasmic Reticulum Stress Activates Cleavage of CREBH to Induce a Systemic Inflammatory Response." Cell 124(3): 587-99.

Zhang, K., Wong, H. N., Song, B., Miller, C. N., Scheuner, D., Kaufman, R. J. (2005). "The unfolded protein response sensor IRE1alpha is required at 2 distinct

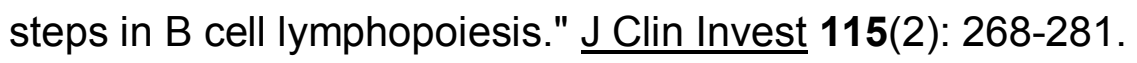

